\title{
THE MAINTENANCE OF PUBLIC ORDER AT SEA AND THE NATIONALITY OF SHIPS *
}

\author{
$\mathrm{BI}$ \\ Mrrees S. MICDougaL \\ Of the Board of Editors \\ WILLiaji T. BuREe aNd IVAN A. Vlasio
}

Yale Law School

\section{INTRODUCTION}

Most comprehensively viewed, the international law of the sea comprises two very different sets of principles. One set of principles, establishing certain basic, overriding community goals, preseribes for all states the widest possible access to, and the fullest enjoyment of, the shared use of the great common resource of the oceans. The other set of principles, commonly described as jurisdictional, expresses certain implementing policies designed economically to secure the basic community goals of shared use by establishing a shared competence among states in a domain largely free from the exclusive public order of any particular state. ${ }^{1}$ The main outlines of the overriding principles preseribing shared use have long withstood the attacks of exclusionary national egoism: the great bulk of the oceans are communis juris, not subject to exclusive appropriation by any particular state; in the interest of the fullest, peaceful, conserving use for the benefit of all mankind, all states are free in complete equality, upon

* This article is a by-product of research aided by the Rockefeller Foundation, for whose assistance the authors express their thanks.

z Fulton, The Sovereignty of the Sea 537-603 (1911); Gidel, Le Droit International Public de la Mer (3 vols., 1932-1934); Smith, The Law and Custom of the Sea (3d ed., 1959); Colombos, International Law of the Sea (3d ed., 1954); Jessup, The Iaw of Territorial Waters and Maritime Jurisdiction (1927).

The theme of complementarity in the prescriptions of the international law of the sea is developed in McDougal and Schlei, "The Hydrogen Bomb Tests in Perspective: Lawful Measures for Security," 64 Yale Law J. 648, 655-661 (1955); McDougal and Burke, "Crisis in the Law of the Sea: Community Perspectives versus National Egoism," 67 ibid. 539, 558-567 (1958).

The principles expressing the basic, overriding community policies about shared use may be observed, further, to exhibit their own special subordinate complementarities. The degree of shared use established by international law is the outcome of a weighing process which explicitly seeks, in the common interest of all states, appropriately to protect and balance both the inclusive interests of the general community of states and the exclusive interests of particular states in protecting their internal value processes. This accommodation of the two types of interests is implemented by complementary prescriptions which both state the broad community policies of protection and point to and weight the specific, detailed factors in the processes of use and claim which must be taken into account for rational balaneing in particular contexts. For further discussion and illustration, see the articles cited above. 
condition of making necessary accommodation for the like freedom of others, to participate to the utmost extent of effective capability in the shared use of this great common resource; the exclusive competence of states is strictly confined to that assertion of authority which is reasonably necessary to protect both their inclusive interest in the shared use of the oceans and their exclusive interest in securing their internal processes from invasions and deprivations originating at sea. ${ }^{2}$

\section{Jurisdictional Principles Built about National Character}

The implementing, jurisdictional, principles by which the general community of states seeks to make effective its overriding policies of shared use have long been built, in response to the omnipresent imperatives of harmonious and economic co-operation, about certain allocations of competence which require high certainty and easy precision in identification of the national character of ships. ${ }^{3}$ For interactions upon the high seas, each state ${ }^{4}$ has imposed upon it responsibility under both customary inter. national law and by many explicit agreements for the lawful conduct of ships to which it has aseribed its national character; each state may apply its authority to the ships to which it has ascribed its national character and to events occurring upon such ships; each state may protect the ships to which it has ascribed its national character against interferences and

2 See, generally, sources eited above, note 1.

3 The distinction between decision that a state's attribution of national character is irrelevant and decision denying a state's competence to attribute nationality is somotimes confused by confusing two different references of the word "nationality." The word may be given both a factual reference and a "Iegal consequence" reference. See Silving, "Nationality in Comparative Law," 5 A. J. Comp. Law 410 (1956).

The factual reference is, of course, to the act, the authoritative decision, of a state in its attribution of national character. The legal consequence reference is to the responses which authoritative decision-makers later make to this fact upon problems of access to the oceans, the application of coercion to vessels, labor relations, taxation, and so on. Thus, by reference to legal consequences the same vessel could be said to have many different "nationalities" for many different purposes-one nationality for access, another for the purposes of application of coercion, another for labor problems, another for taxation, and so on.

The employment of the word "nationality" in the second reference, to legal con. sequences, leads, we suggest, to unutterable confusion in discussion and encourages the invocation of wholly irrelevant contexts and decisions in argument and policy applications. It has all the vices which are elsewhere categorized as "normative-ambiguity." See Lasswell and McDougal, "Legal Education and Public Policy: Professional Training in the Public Interest," 52 Yale Law J. 203 (1943).

In this article we shall use the word "nationality" to refer to the fact that a state attributes its national character to a vessel. The legal consequences which other authoritative decision-makers attach to this fact we propose to explore in a series of carefully delimited problems, raising in very different degree the policy relevance of thix fact.

"Our reference in this article is only to "recognized" states. The special difficulties arising with respect to unrecognized states are so complex as to require separate treatment. Some of these difficulties appear in The Maret, 145 F. 2d 431 (1944). See alur, Briggs, "Non-Recognition in the Courts: The Ships of the Baltic Republics," 37 A.J.I.I. 585 (1943). 
deprivations by others. ${ }^{5}$ No state may preclude the ships of other states from access to the high seas or directly apply its authority to the ships of other states, except as may be authorized by international law. Every ship is required to have a national character, and scant protection is afforded ships which have no nationality. For interactions within their internal waters and territorial sea, coastal states are of course authorized to assert authority over ships of other states for the protection of their exclusive interests, but states which have ascribed their national character to these ships are also conceded a limited concurrent jurisdiction for the protection of their interests. ${ }^{8}$

\section{Attributions of National Character Traditionally Conclusive}

The necessary high certainty and easy precision in identification of the national character of vessels, required by such jurisdictional principles, have traditionally been achieved by according states a virtually conclusive unilateral competence to confer their nationality upon vessels. The mode by which national character has traditionally been conferred upon vessels has been by the simple act of a state in making formal attribution through appropriate registration and documentation." Historically states have, of course, as a matter of domestic policy, conditioned their bestowal of national character upon vessels by many different criteria. But as a matter of international law, until very recent date, states have universally been regarded as possessing a practically unlimited discretion in their choice of criteria. $^{8}$ The only limitation commonly accepted has been that a state

5 Thus Professor A. P. Higgins states: "La nationalité du navire est l'une des garanties fournies par le droit international pour la liberté de la navigation, et tout bâtiment nariguant en haute mer doit avoir un caractère national et être en mesure d'en établir la preuve. La possession d'une nationalité sert de base au contrôle et à la protection exercés par l'État du parillon; c'est aussi une garantie pour les autres États au point de vue de la répression des torts dont peuvent se rendre coupables les gens qui sont à bord. Les conditions fixées par les Etats pour l'acquisition de la nationalité 'ont pour objet d'assurer la possibilité ou d'accroître la facilité et l'efficacité du contrôle, en permettant de reconnaître à distance la qualité, la nationalité des navires.' " Higgins, "Le régime juridique des navires de commerce en haute mer en temps de paix," 30 Hague Academy Recueil des Cours 5, at 20 (1929, V).

- Jessup, op. cit. note 1 above; 3 Gidel, op. cit. note 1 above; Colombos, op. cit. note 1, above; Rienow, The Test of the Nationality of a Merehant Vessel (1937); Potter, The Freedom of the Seas (1924); United Nations Secretariat, Memorandum on the Regime of the High Seas, U.N. Doc. A/CN.4/32 (1950).

7Rienow aprropriately emphasizes the rôle of the state: "To impress effectively its nationality on vessels and to be assured that such nationality will be respected, a State must take certain established steps intended to make other States cognizant of certain particulars: that the vessel has met to the satisfaction of the State all the statutory conditions; that the State considers the vessel one of its own. These are the points which the practice of the United States, and that of foreign States, has consistently exemplified." Rienow, cited above, at 116.

\% This conclusion is confirmed by almost any source to which one turns. Thus, half a century ago, Westlake wrote: "TThe conditions on which different states admit ships to their register, or otherwise grant them the right to carry their mercantile flag, are very various... [b]ut with such conditions international law has no concern: it suffices 
may not confer its national character upon a vessel already having the national character of another state. ${ }^{9}$ The rationality of this simple system is attested by the high degree in which the states of the world have in modern times achieved their community objectives in the shared uses of the oceans.

\section{The Proposed Subversion in Genune Link}

Unfortunately, in recent years efforts have begun to be made to limit the exclusive competence of states to ascribe their national character to vessels by new and ill-defined criteria which would confer upon states a unilateral competence to question, and even deny, each other's ascription of nationality. These efforts have culminated in the recently formulated Convention on the High Seas ${ }^{10}$ which, if adopted and interpreted as some suggest, might introduce vast and costly uncertainties into the simple, rational, inherited system. Article 5 of this convention, after correctly emphasizing the traditional exclusive competence of each state to determine the conditions for the ascription of its national character to ships, projects a newly devised restriction upon this competence in the form of an undefined requirement of a "genuine link." The relevant words of Article 5 read:

There must exist a genuine link between the State and the ship; in particular, the State must effectively exercise its jurisdiction and control in administrative, technical and social matters over ships flying its flag.

Beyond the extraneous eriteria introduced by the words "in particular," the convention nowhere specifies what content is to be written into "genuine link." Still more confusingly, the convention leaves entirely unspecified such vital matters as who is to apply the requirement and what sanctioning consequences are to be attached to failure to conform. The drastic potentialities of possible interpretations are, however, made all too clear in the formative discussions in the International Law Commission and in the appraisal of subsequent commentators. Thus, Professor Max Sørensen, Chairman of the Danish Delegation at the Geneva Conference, in a pamphlet published under the auspices of the Carnegie Endowment, takes

that, for whatever reasons, a state accepts the authority and responsibility which result from the ship's nationality.", 1 International Law 169 (2d ed., 1910).

The Italian scholar Fedozzi expressed this unilateral competence in even stronger language: "Tout les États maritimes déterminent dans la plénitude de leur autonomie, les conditions de la reconnaissance ou de la concession de leur nationalite aux navires marchands et les documents nécessaires pour la preuve de la nationalité elle-même." "La condition juridique des navires de commerce," 10 Hague Academy Recueil des Cours 5, at 49-50 (1925, V).

Professor Sørensen puts it this way: "International law has traditionally left each state free to determine under what conditions it will register and thereby confer its nationality upon a ship." Sørensen, The Law of the Sea 202 (International Conciliation, Pamphlet No. 520, 1958).

9 See Rienow, op. cit. note 6 above, at 16.

10 U.N. Conference on the Law of the Sea, Official Records, Vol. II, Plenary Meetings, p. 135; 52 A.J.I.L. 842 (1958). (Hereinafter references to this convention are made merely by citing the relevant article where that is appropriate; otherwise no citation will be given.) 
for granted that states may determine unilaterally whether a genuine link exists, and surmises that, if such a link between a vessel and the state does not exist,

a foreign state should be free not to recognize the purported nationality of the ship and to treat it as a stateless ship, having no right of access to its ports. ${ }^{11}$

Professor Philip Jessup, building upon Professor Sørensen's conclusions, notes that the genuine link theory applied by the International Court of Justice with respect to individuals in the Nottebohm Case, "could easily be utilized internationally to determine the national character of corporations and ships," and boldly predicts that the

law is in the process of development; the most that can be said is that, in the light of the court's opinion in the Nottebohm Case, it is probable that if the issue were presented to it, that tribunal would sustain the link theory in its application to the nationality of ships. ${ }^{13}$

Writing shortly before the Geneva Conference and obviously stimulated by the final Draft Articles adopted by the International Law Commission, a British author, Mr. A. D. Watts, in a major article on the protection of merchant ships, concluded that national ownership and not registration, i.e., nationality of owners, should be "the proper basis for the exercise of protection over private shipping." 14 In the opinion of Mr. Watts, a flag state should not be allowed to "protect" its ships until it has been established that there exists between them a "strong link," or a "real and effective link," or, at least, an "effective link." 15

The uncertainties and potential dangers introduced by the convention in Article 5 are still further compounded by observing that the text of this article may be interpreted to embrace not one test but two tests. The words: "in particular, the State must effectively exercise its jurisdiction and control in administrative, technical and social matters over ships flying its flag" could be construed to mean that, even though a ship has passed a genuine link test, it may still fail to satisfy the additional criteria imposed by the quoted words. Even though a state's attribution of national character to a ressel may not be subject to challenge under any of the commonly proposed references of genuine link, one state might still, under the

11 Sørensen, note 8 abore, at 203. Professor J. H. W. Verzijl's speculation about genuine link indicates even more clearly the possibilities of chaos. After alleging that the "genuine link" is "now defined as to its main parport" and noting that the convention provides no sanction, Professor Verzijl declares that:

"However, under these conditions international tribunals, municipal legislatures and municipal courts would seem to have been given a free hand to attach to the general requirement of 'genuine link' the legal consequences they deem fit and proper." Verzijl, "The United Nations Conference on the Law of the Sea, Geneva 1958," 6 Nederlands Tijdschrift voor Internationaal Recht 115, 118 (1959).

12 Nottebohm Case (second phase), Judgment of April 6, 1955, [1955] I.C.J. Rep. 4 ; 49 A.J.I.L. 396 (1955).

18 Jessup, "The United Nations Conference on the Law of the Sea," 59 Columbia Law Rev. 234, at 256 (1959).

14 Watts, "The Protection of Merchant Ships," 33 Brit. Yr. Bk. Int. Law 52, at 84 (1957). Is Ibid. at $68,73,67$. 
assumed authority of these words, challenge such attribution and impose unspecified sanctions because the flag state does not assert sufficiently "effective" control over the ship's, say, "social matters." 16 No more than for "genuine link," does the convention anywhere specify meaning for "effective," "jurisdiction" and "control," or for "administrative, technical and social matters." Since inherited traditions do not provide a reliable guidance, it is again left to every state unilaterally to determine the applicable standards and appropriate sanctions.

\section{IrReievant Demands By Labor aNd Business}

It is easily observed that the proposed innovations in the convention for identifying the national character of ships have been primarily stimulated by certain pressure groups, including both seamen's unions and shipowning interests, acting on both national and international levels.

The perspectives of the pressure groups representing labor, as well as the wide range of interests which they seek to secure by application of the "genuine link" concept, are fully documented in the proposals submitted by the Seafarers' members of the International Labor Organization to its Committee on Flag Transfer. This unique document is so concise and comprehensive as to merit quotation at length :

The Seafarers' group has considered points in relation to flag transfers and submits that the following points should be considered in relation to any form of instrument which is finally adopted:

1. Notice to be taken of the declaration made by the International Luw Commission of the United Nations on the subject of merchant ships having a broader link with the country of registration than merely the formality of registration.

2. The country of registration to have greater and more intimate jurisdiction over ships flying its flag, possibly by requiring that-

(a) ships should be owned by companies having their principal place of business in the country of registration;

(b) each company shall have nationals of the registering country on

its board of directors ;

(e) meetings of the boards of directors shall be held within the territory of the registering country.

3. To make and adopt regulations designed to ensure that all ships flying its flag observe internationally accepted safety standards.

4. To establish and operate a government-controlled ship inspection service within its territory adequate to the requirements of the tonnage on its register and to ensure that all ships flying its flag are regularly inspected within its territory to ensure conformity with regulations issued under 3 above.

5 . To lay down regulations governing the recruitment, engagement and discharge of seafarers serving in its ships according to internationally accepted standards and establish the requisite governmentcontrolled agencies to give effect to such regulations.

6. To lay down regulations or legislation providing that not less than 25 percent of seafarers in any one ship are nationals of the country of registration.

16 Compare below, p. 108, for potential requirements relating to labor conditions, a statement by Mr. Jenks, the I.L.O. representative at the Genera Conference. 
7. To make and adopt regulations or legislation, if such do not already exist in the country, providing for the freedom of association of its seafarers.

8. To ensure by regulation that proper repatriation for its seafarers be provided.

9. To provide that seafarers will be covered by social security arrangements which in any case shall not be less than those provided for workers in other countries.

10. To ensure that proper and satisfactory arrangements are made within the country concerned for the examination of candidates for certificates of competency and for the issuing of such certificates. ${ }^{17}$

The seriousness with which these proposals are made is confirmed by the report that the International Transport Workers' Federation, in calling for a worldwide boycott of the ships flying flags of convenience, sought to attain the following objectives: (1) "All ship owners should make monthly payments of $\$ 5.60$ for each crew member into federation funds"; (2) "Costs should be standardized for all shipping companies"; (3) "Pay for all merchant seamen should be equalized." 18 The Federation expressed the hope that the boycott will eventually result in forcing all shipping companies "into line with federation rules." 19 Reviewing the causes of this boycott, a New York Times report asserted that it "involves so many facets that some of the central protagonists are confused as to the reasons for the boycott, and even its objectives." The article continues:

The major unions around the world that have been pressing for action against "flags of convenience" now speak of the boycott as an economic wedge. They would use it to force the so-called runaway shipping lines to establish better union wage scales and working conditions.

Despite the emphasis on unionization much of the fleets under the Liberian and Panamanian flags are now fully unionized.

Another point that has been stressed in the past by the union critics has been safety. They charge that the runaway ships are not subject to the same standards as those imposed by the traditional maritime countries.

This is another point that is reportedly no longer really valid. ${ }^{20}$

Writing on the same theme in an article entitled "Union Contract is Ship Boycott Goal," a staff correspondent of The Christian Science Monitor described the agitation about the flags of convenience as "the case of elusive employers being chased by unions." With apparent knowledge of the real causes behind labor's demands, he states:

Neither side [i.e., shipowners and seamen] appears much concerned over what flag flutters from the ship's stern. But the conflict is being waged with no less vigor because it revolves around dollars and cents.

17 International Labour Conference, 41st Session, 1958, Flag Transfer in Relation to Social Conditions and Safety 5 (1957).

18 New York Times, Nor. 15, 1958, p. 40. More recently it was reported that the aim of the American unions is to obtain for seamen serving on "runaway" ships the American wage scales " ... in most cases double and frequently treble those of European Maritime nations. ..." Ibid., Aug. 19, 1959, p. 58.

39 Ibill., Nor. 15 , 1958 , p. 40.

20 Ibid., Nov. 30, 1958, p. 48. 
While American unions demand the return of vessels to the American flag, indications are they were more interested in obtaining contracts than in a return to the native colors.

"It is immaterial to us whether these ships come back under the United States flag" said a spokesman for the Seafarers International Union, one of two large maritime unions involred in the boycott."1

The perspectives which inspire the shipping interests are equally matters of common knowledge. Thus Professor Sørensen, a proponent of the "genuine link"' test, after alluding to certain unspecified abuses by states of their freedom to preseribe the conditions of the attribution of their nationality to ships, summarizes as follows:

The problem of registration under flags of convenience was first raised by the International Transport Workers' Federation shortly after the Second World War as a problem affecting the economic and social security of seafarers. Because of improved conditions in the many modern ships registered under flags of convenience, the emphasis has shifted since then. The problem is now also riewed as one of economic competition between the merchant fleets of traditionally maritime countries and the new and efficient vessels operating with lower costs under the flags of countries to which they are attached only by the administrative formality of registration. ${ }^{2: 2}$

No less specific is a report on shipping by the Organization for European Economic Co-operation which states:

... [the] virtual freedom from taxation of ships sailing under the flags of convenience enables many of the shipowners concerned so to arrange their business enterprises that their profits are not liable to taxation in any country. They are thus able to devote to the expansion and development of their fleets that proportion of their profits which their competitors in other countries have to set aside to meet tax requirements.

21 F. W. Roevekamp, The Christian Science Monitor, Dec. 2, 1958, p. 2.

22 Loc. cit. note 8 above, at 203. (Emphasis added. Throughout this article emphases are ours unless indicated otherwise.)

In 1949, the International Dockers' and Seafarers' Conference adopted a resolution in which it was stated:

"Having heard reports from Britain, Holland, Norway and Sweden about the sale to Panamanian registry of ships which are obsolete or uneconomic or which could not continue operation under their original flags because they no longer satisfy the survey, safety and other requirements of those countries ...

\footnotetext{
"Condemns the practice as menacing the established standards of the shipping industry and calculated to place the traditional maritime countries at a serious dis. advantage." I.L.O., Conditions in Ships Flying the Panama Flag 46 (1950).

Invited to elaborate on these charges by the I.L.O. Committee of Enquiry, especially established to investigate the matter, Mr. Oldenbroek, General Secretary of the International Transport Workers' Federation, described the conditions of, and in, these ships as "chaotic," "very old," "lacking discipline", and with low standards of safety. Requested by the I.L.O. Committee of Enquiry to supply "more specific and detailed in. formation on the charges brought by the I.T.F.," Mr. Oldenbroek promised to comply within a fortnight. However, "despite repeated requests," the Committee was com. pelled to report with "regret" that "except for one or two rague and meagre documents, none of the information in question was received from the I.T.F.' Ibid. at 4 , 5 and 7.
} 
The real effect of such registrations is to bring the high operating costs incurred by ships registered in the U. S. down to a level nearer that of the general run in the countries of their foreign competitors. In a sense, therefore, it is the removal of a handicap rather than the gaining of an advantage which flows from these particular transfers. ${ }^{23}$

A further illustration of the same perspectives is provided by the following comment :

British and Norwegian shipowners have been pressing for some solution to the convenience fleet problem by urging that all ships be able to prove that a "genuine link" exists between vessels and the flags they carry. However they have encountered great difficulty in defining the term "genuine link."

They have therefore welcomed actions taken by trade unions against convenience ships. ${ }^{24}$

Thus, although on the question of boyeott in an unusual solidarity with their employees, the shipowners in traditional maritime countries, nevertheless, "admitted these measures did not constitute effective answers to the threat they faced from flag-of-convenience shipping." ${ }^{25}$ The variety of ills affecting the shipping industry is more fully summarized by the president of the United Kingdom Chamber of Shipping, who sees British shipping interests endangered not only by the flags of convenience but by two more "deadly enemies," flag discrimination and subsidized merchant marines. ${ }^{*}$ Some indication of the realism of the concern exhibited by maritime nations for their competitive position is indicated by an editorial comment in a British business magazine:

23 Quoted in New York Times, April 6, 1958, p. 78, col. 1. Apparently the reference, unarailable to $u s$, is to "Study on the Expansion of the Flags of Convenience Fleets and Various Aspects Thereof,"' O.E.E.C. Doc. C (57), Jan. 28, 1958, cited in Sørensen, lor. cit. note 8 above, at 203 , note 9 .

24 New Fork Times, Aug. 31, 1958, \$ 5, p. 11.

25 Ibial.

$\because 6$ Mr. Robert D. Ropner in New York Times, Nor. 20, 1958, p. 70. Lord Winster's list of complaints is even longer. Here are some samples:

(1) "For instance, there is the question of subsidies."

(2) "The trouble is that the depreciation allowed for taxation purposes is not proportionate to current replacement rates; and that fact, coupled with inflation, makes it diffieult, if not impossible, for shipowners to replace ships ont of earnings."

(3) "Frcight rates have fallen catastrophically. . . ."

(4) ". ... there is today far too much tonnage in existence for too little cargo."

(5) "In shipbuilding, costs continue to rise."

(6) "An allied handicap to our shipping is flag discrimination. . . The evil is on the increase." 208 Parliamentary Debates, House of Lords 323-330 (March 20, 1958).

It should not be supposed that the pot and the kettle are any more distinguishable here than in other contexts. Thus Viscount Runciman conceded:

"Indeed, I think it would be quite difficult for us in this country to complain unduly of people using other flags than their own for the purpose of reducing their costs of operation. I have only to remind your Lordships of the considerable volume of Canadian-owned tonnage which is registered in this country at present for precisely that reason-a fact of which I do not think any of us is likely to complain. After all, to a certain point we must recognise that 'fair's fair.' ", 208 Parliamentary Debates, House of Lords 341 (March 20, 1958). 
The argument from safety often levelled against "Panholib" registered shipping . . . ignores certain facts. While it may be true that "Panholib" shipping is not regulated by legislation so stringent in matters concerning safety, health and welfare as that of traditionil maritime nations, Panholib vessels in practice tend to be newer, with obvious advantages. And the vessels are classed and insured in the same way as those in traditional fleets; one need hardly say that insurers, perhaps less optimistic but equally as interested as Governments in respect of the subject matter of their policies, set their own standards, which are naturally high. ${ }^{27}$

\section{Demanded Remedies Dangerous and Uneconomic}

It is believed that the innovations found in Article 5 of the Geneva Convention derive from certain fundamental misconceptions of problems and relevant policies. These innovations fail to distinguish the many very different types of problems in which the national character of ships is a factor, to delineate the policies uniquely relevant to the different types of problems, and to recommend remedies appropriate to the different problems. These innovations further completely misconceive the function served in maintaining a shared competence over the oceans by states' attributions of their national character to vessels and the varying degrees of importance that should be aseribed to these attributions on many different problems. In justifiable endeavor to correct certain acknowledged evils, they recommend remedies which are both uneconomic in relation to the specific evils to which they are addressed and positively dangerous in that they imperil many still cherished policies of the international law of the sea.

Even the most casual inspection of the recommendations submitted to the International Labor Organization, quoted above, indicates that the problems about which labor is genuinely and appropriately concerned are very dif-

27 5 Business Law Rev. 62-63 (1958). This statement, as far as it concerns the alleged abuses of safety by the ressels flying the flags of convenience, finds its most eloquent corroboration in the following words of the chairman of the American Bureau of Shipping, where the majority of these ressels are classified:

"The inference has frequently been drawn that the ships of these fleets are substandard with respect to design, maintenance, safety equipment, et cetera. . . .

" It can be truthfully said with respect to those ships classed by the bureau that any such implications are unwarranted. From the standpoint of original design, maintenance and safety, the ships of these fleets compare most farorably with the fleets of any other of the maritime nations in which the bureau has active participation.

"There is in some quarters a belief that the fleets of Liberian and Panamanian registry are comprised largely of older ships sold out from under the flags of original registry as they are replaced by newer and more modern ships. Such beliefs are completely unfounded." New York Times, Jan. 28, 1959, p. 61.

Similarly, in a major address in the House of Lords, Lord Winster stated: "Some. times people speak to me as if this tonnage under flags of convenience were comparable with the kind of second-hand motor car that one sees for sale outside garages on the Great West Road. It is not second-hand tonnage at all. The greater part of it is new and efficient tonnage. Some 35 per cent. of the tonnage under these flags is under five years old. Our comparative figure is 22 per cent., so we must not imagine that this is second-hand tonnage." 208 Parliamentary Debates, House of Lords 329 (Mareh 20, 1958). 
ferent problems from those involved in the maintenance of the public order of the high seas with respect to which high certainty and easy precision in identification of the national character of vessels is so important. It will be observed that these problems which concern labor are essentially related to usual labor unions' demands such as better working conditions, higher wages, better and more abundant job opportunities, greater sharing in profits derived from maritime commerce and trade, more comprehensive social security, and the like. However much one may, and does, sympathize with these objectives of seafarers, it should not be overlooked that the perspectives behind the proposals submitted to the International Labor Organization by the representatives of labor embrace so many irrelevant and abuse-prone standards that, should they be adopted as conditions upon which to base the recognition of states' ascription of their national character to ships, the unimpeded flow of ocean trade would be placed in serious jeopardy. It does not seem that the most economic sanction for these standards should be a denial of the validity of a state's attribution of national character to vessels. On the contrary, the authorization of such denial by unilateral decision of other states, as proposed, must necessarily endanger the freedom of the seas and in particular the most vital element of this freedom-freedom of access. ${ }^{28}$ Certainly there are available alternatives for the establishment and maintenance of appropriate labor standards which do not involve such disproportionate risk.

It is equally obvious that the principal problem with which the shipping interests are concerned, that is, the maintenance of their competitive position in world maritime commerce and trade, is also a very different problem from those with which the traditional law of the sea is concerned. The problem with which the shipping interests are concerned is basically that of competition within the industry. Thus, Professor Sørensen again provides the best testimony to this by correctly stating that what is really at stake "is a problem of the regulation of international competition in an important industry rather than a problem of the law of the sea." ${ }^{29}$ The drastic innovation proposed in the "genuine link" requirement for determining the nationality of ships not only is no solution to this problem of competition, but, by permitting unilateral decision to interfere with traditional inclusive uses, may positively endanger appropriate solution. The whole of the international law of the sea, including both basic policies and jurisdictional principles, has long been based upon the historically verified postulate that the greatest production of values for the entire community is to be achieved by the highest degree of internationalization, with the freest access by all, and with only those restraints necessary to safeguard productivity and the fewest possible restraints in favor of particular

28 It was reported that some Geneva Conference "observers" interpreted the meaning of the genuine link standard as follows: "A nation unfriendly to the United States could, by applying the genuine link criterion, refuse to recognize the nationality of a Liberian ship owned by United States interests" and "delay the ship, refuse to admit her to port, or at worst, seize the ship and her cargo." New Yoris Times, April 9, 1958 , p. 66.

" Lac. cit. note 8 above, at 205 . 
exclusive national interests. Any unnecessary interference with the traditional freedoms of access and shared competence can be expected only to reduce the total amount of values created for sharing among all participants in the exploitation of the oceans. Instead of attempting to kill the goose that lays the golden egg, states finding themselves in a diffienlt competitive position might well consider appropriate changes in their own fiscal and tax legislation or, perhaps, a more economic allocation of their resources. ${ }^{30}$ A commentator in a British business magazine has provided a sober suggestion. He states:

The balance can be reversed by measures designed to relieve the "traditional" shipowner of the burden of taxation to a considerable extent, but the rights and wrongs of such a course are matters of economics and politics, not law. ${ }^{31}$

- So far, at least one state has taken this course and the results have already abundantly proved that action on a national level can bring about desired outcomes most rapidly and at least cost. ${ }^{32}$

\section{The Derivation From NotTebohm}

It is perhaps worth noting that certain of the contemporary misconceptions about the rôle of the nationality of ships appear to derive from over-extrapolations of the Nottebohm decision. The International Law

30 Addressing the meeting of the representatives of the United States and nine West European nations held in June, 1959, in Washington, D. C., Under Secretary of State Dillon said:

"'To the extent that there is actual tax avoidance through the use of tax harens, it seems to me that this is, first and foremost, a problem for the tax authorities in the particular conntry whose taxes are being avoided. This is obviously a complex problem with ramifications far beyond the shipping field. As a practical matter, if differences in national tax policies cause difficulties for shipowners, it would appear that the solu. tion, at least in the short run, may have to be found by the individual country which considers that its owm shipowners are operating at a competitive disadvantage." 41 Dept. of State Bulletin 14 (1959).

Viscount Simon, a former President of the British Chamber of Shipping, in a debate on merchant marine in the House of Lords, deseribed the causes of the ills which burden the British shipping industry very realistically:

"I think it is perfectly clear that there are only two things which are really re. sponsible for this languishing position. One is unavoidable. It is the fact that shipping is an international business in which the British shipping industry is in competition with the whole world, and therefore the rate of reward must be less than the rates in more sheltered industries. And because the reward is less, it is more difficult to attract capital. . . The other difficulty under which we languish is the burden of tax. It is not merely the level of taxation but the system as applied to industry. ...

"The position would clearly be serious enough, even if there were not the matter of fiags of convenience, to which reference has been made." 208 Parliamentary Dobates, House of Lords 356-357 (March 20, 1958).

315 Business Law Rev. 63 (1958). In citing this stricture for our purpose we are not to be taken as approving the distinction between law and politics.

32 Thus, during a single year, the Greek merchant fleet gained 955,083 gross register tons, much of which "'has been attracted to the Greek flag by the revision of the nation's maritime legislation." New York Times, Sept. 8, 1959, p. 56. 
Commission seems to have been the first to attempt to transplant the prineiple of "real and effective" link there enunciated into the wholly different environment of the law of the sea. In seeking to provide an "account of the background" to the Commission's articles on the law of the sea for the use of the General Assembly, the United Nations Secretariat observed:

In connexion with the question of the nationality of ships, it may be noted that, in the Nottebohm case, the International Court of Justice enunciated certain principles concerning the duty of one State to recognize the nationality legislation of another State. Although this case concerned the nationality of individuals ... the Court considered the matter of nationality in general terms. It is possible, therefore, that some of the principles laid down by the Court may be relevant to the question of the nationality of ships; in particular, to the question of the circumstances under which one State may or may not be obliged to recognize the national character of ships of other States. ${ }^{33}$

This suggestion was readily accepted by $\mathrm{Mr}$. Watts, who begins his article on the protection of merchant ships with the statement that "the right to protect a ship does not necessarily belong to the State whose nationality that ship has, nor is the legitimacy of ascribing to a ship a nationality of its own acceptable without question," basing these views on both the decision of the International Court in the Nottebohm Case and the acceptance and extension of the principle there enunciated by the International Law Commission in its draft Article 29 (now Article 5 of the convention). ${ }^{34}$ Professor Sørensen is even more explicit in dependence on the Nottebohm decision :

It is well established that each state has the right to determine the conditions under which it will grant its nationality to an individual, but a state is not in all circumstances bound to respect a naturalization effected by another state. Only if the grant of nationality is based upon a genuine connection between the state and the individuals, and is thus the legal expression of a real and effective nationality, can it be invoked against foreign states as a valid legal act. ${ }^{35}$

The reliance placed by Professor Jessup upon the Nottebohm Case has already been mentioned. Spokesmen from New Zealand and Norway at the Geneva Conference also referred to the Nottebohm decision as providing a useful analogy. Thus the representative of New Zealand stated:

If any State purported to confer its nationality upon an individual, that action would not, in ordinary circumstances, be questioned by other States. But, in the exceptional case, other States had the right to look behind the form and to examine the substance. The principle of the "genuine link" embodied a parallel rule in regard to the nationality of ships, and the granting of a flag must not be a mere administrative formality. ${ }^{36}$

as U.N. General Assembly, 11th Sess., Official Records, Agenda Item 53, Annexes, p. 39 (1956-1957).

34 Loc. cit. note 14, at 52. $\quad 35$ Loc. cit. note 8, at 204.

36 Mr. Waite, speaking in the Second Committee. United Nations Conference on the Law of the Sea, Official Records, Vol. IV, Second Committee (High Seas: General Regine), p. 65, U.N. Doe. A/CONF. 13/40 (1958) (hereinafter cited as Official Records with appropriate rolume number). 


\section{The NottebonM Decision Slightlly Over-Extrapolated}

It is not difficult to demonstrate that the policy which the International Court of Justice regarded itself as applying in the Nottebohm Case has little, if any, relevance to problems in which the conclusiveness of a state's attributions of nationality to a ship is at stake. Thus, the Court itself very strictly delimited the scope of its decision. To counsel's argument that "the essential question is whether $\mathrm{Mr}$. Nottebohm, having acquired the nationality of Liechtenstein, that acquisition of nationality is one which must be recognized by other States," 37 the Court responded:

This formulation is accurate, subject to the twofold reservation that, in the first place, what is involved is not recognition for all purposes but merely for the purposes of the admissibility of the Application, and, secondly, that what is involved is not recognition by all States but only by Guatemala. ${ }^{38}$

Guatemala, the Court emphasized, had been the "main seat" of Nottebohm's activities for 34 years and remained "the center of his interests and of his business activities"; Nottebohm had been a German national from birth and had shown no desire to "dissociate himself from the government of his country"; Nottebohm's "actual connections with Liechtenstein were extremely tenuous" and "it was impossible to disregard the circumstances," including the fact that Germany was at war, under which Liechtenstein had conferred its nationality. ${ }^{39}$ Even with respect to individuals, not to mention ships, the scope of the Court's actual decision is, accordingly, most severely confined. The Court makes clear, further, that the prior decisions upon which it depends most heavily in creating its new concept of "genuine link" are cases of "dual nationality." In such cases, arbitrators, the Court states, "have given their preference to the real and effective nationality, that which accorded with the facts, that based on stronger factual ties between the person concerned and one of the States whose nationality is involved." ${ }_{40}$ By accepted principles regarding the competence of states to confer nationality upon individuals, several states may confer their nationality upon the same individual, even though that individual never budges from the hamlet of his birth; hence, the attribution of no one state can be regarded as automatically conclusive, and international decision-makers must have criteria for choice. ${ }^{11}$ With respect to ships, in

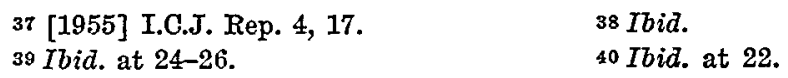

41 On many problems, international practice has of course attributed a very high degree of conclusiveness to a state's attribution of nationality to an individual. Briggs, The Law of Nations 471 (2d ed., 1952); Parry, "The Duty to Recognise Foreign Nationality Laws," 19 Zeitschrift für Ausländisches Recht und Völkerrecht 337 (1958); Weiss, Nationality and Statelessness in International Law 200 et seq. (1956); Silving, "Nationality in Comparative Law," 5 A. J. Comp. Law 410 (1956). This poliey reinforces the policy we recommend for vessels.

The special difficulty with respect to individuals is, as indicated in the text, that an individual may lawfully acquire more than one nationality. In such instances, when different states make competing claims to the same individual, a tribunal must choose between claims and, if the decision is to be a "reasoned" decision in terms of community policy, must necessarily establish some criteria of choice. In establishing such 
contrast, by principle which has never been directly questioned, attribution of nationality by one state precludes all subsequent attributions so long as the first endures, and international decision-makers are confronted by no necessity to choose between competing claimants. The criteria which the Court specifies for giving content to its concept of "genuine link" are, again, quite clearly relevant only to human beings and wholly inapplicable to inanimate objects, like ships. The Court states :

... the habitual residence of the individual concerned is an important factor, but there are other factors such as the centre of his interests, his family ties, his participation in public life, attachment shown by him for a given country and inculeated in his children, etc. ${ }^{42}$

Later the Court refers to "demographic factors" and deseribes nationality as

a legal bond having as its basis a social fact of attachment, a genuine connection of existence, interests and sentiments, together with the existence of reciprocal rights and duties. ${ }^{43}$

To derive from applications of criteria of this type to the competence of states to confer nationality upon individuals, principles assumed to be relevant to limiting the competence of states to attribute nationality to ships is, if not an exercise in irrelevancy, certainly a disguised mode of stating that because certain limits have been imposed on states with respect to individuals for some problems, other limits ought to be imposed with respect to ships for other problems. ${ }^{44}$

It is by no means clear, furthermore, precisely what generalizations may be derived from the Nottebohm Case for projections into the future as dependable or desirable policy even with respect to individuals. The decision in the case has been severely criticized by commentators for the limitations which it imposes upon the international protection of human

criteria, the polieies so vaguely adumbrated in the concept "genuine link" could perhaps be elaborated by appropriate operational indices to serve community purposes.

With respect to vessels, however, this necessity for establishing criteria for choice between competing claimant states does not arise. The insistent requirements of public order upon the high seas have forced states to establish a simple rule of priority in time: the first attribution of national character to a vessel precludes all later attributions. To superimpose upon this clear and easily applicable policy any further requirements, which states may use at their unilateral discretion, to the genuineness of the first attribution would be entirely to defeat this policy.

42 [1955] I.C.T. Rep. 4, at $22 . \quad 43$ Ibid. at 23.

*4 The Court placed great emphasis upon "special circumstances" under which the change of Nottebohm's nationality had been obtained and in no doubtful terms expressed its conviction that the real purpose of the change was "to enable him to substitute for his status as a national of a belligerent state that of a national of a neutral state." Ibid. at 26 . "Guatemala is under no obligation to recognize a na. tionality granted in such circumstances," concluded the Court. Ibid.

Throughout its decision the Court stresses the importance of allegiance, motivation, spiritual association and similar mental processes-all of which are quite obviously inapplicable to inanimate ressels. To read the Nottebohm decision as supporting the "genuine link" doctrine with respect to vessels indeed requires both great imagination and disregard for some all-important physical and legal factors. 
rights, ${ }^{45}$ and there is much cogency in some of the reasoning in the dissenting opinions. The remarks of Judge Read about the importance of not permitting unilateral challenges upon undefined grounds of a state's act in attributing nationality to individuals might be more persuasive, in affecting the course of future decision, than the majority opinion. Judge Read summarized:

Nationality, and the relation between a citizen and the State to which he owes allegiance, are of such a character that they demand certainty. When one considers the occasions for involking the relationship-emigration and immigration; travel; treason; exercise of political rights and functions; military service and the like-it becomes evident that certainty is essential. There must be objective tests, readily established, for the existence and recognition of the status. That is why the practice of States has steadfastly rejected vague and subjective tests for the right to confer nationality-sincerity, fidelity, durability, lack of substantial connection-and has clung to the rule of the almost unfettered discretionary power of the State, as embodied in Article I of The Hague Draft Convention of 1931.

Nationality and diplomatic protection are closely inter-related. The general rule of international law is that nationality gives rise to a right of diplomatic protection. ${ }^{* 6}$

Whatever the importance of certainty, and whatever the course of future decision, with respect to individuals, however, differences in the context of interaction and the fundamental community problems presented make certainty of national character an indispensable policy with respect to ships. The fact of decisive significance, in distinguishing the policy requirements relating to ships from those relating to individuals, is the fact that the conclusiveness of a state's attributions of national character to vessels is, in the present decentralized world arena, indispensably necessary to protect that state's share in the inclusive competence of all states over the oceans. ${ }^{47}$ The nationality of individuals, however important to state power and human rights, serves no comparable community function.

45 "One cannot, however, view with much confidence the development of an international jurisprudence on the basis of the link theory without any reference to the criteria in the light of which it is to be applied. Whatever these criteria may be they must certainly result in the creation of fresh, and potentially large, classes of unprotected persons. The effects of judicial 'legislation' in the sphere of municipal law can be limited or corrected by true legislation; in the international field this is not possible." Jones, "The Nottebohm Case," 5 Int. and Comp. Law Q. 230, at 244 (1956). See also Parry, "Some Considerations upon the Protection of Individuals in International Law," 90 Hague Academy Recueil des Cours 657, at 705 et seq. (II, 1956); Simpson and Fox, International Arbitration 107 (1959).

46 [1955] I.C.J. Rep. 4, Dissenting Opinion of Judge Read, p. 46. Article 1 of the Convention Concerning Certain Questions relating to the Conflict of Nationality Laws, signed at The Hague on April 12, 1930, provides: "It is for each State to determine under its own law who are its nationals. This law shall be recognized by other States in so far as it is consistent with international conventions, international custom, and the principles of law generally recognized with regard to nationality." 5 Hudson, In. ternational Legislation 364 (1936).

47 Upon many problems, such as those said to relate to the "internal affairs" of a business enterprise, international practice has accorded a very high degree of im= 


\section{Manifold Dangers to Shared Use and Competence}

The dangers for the free and ordered use of a great common resource on the basis of equality and certainty of expectations, which such an illconceived innovation as the "genuine link" requirement creates, can hardly be exaggerated. As the Mexican delegate at the Geneva Conference emphasized,

by conceding to other states the right to decide for themselves whether there was a genuine link between the ship and the flag state, the Commission had opened the door to the creation of insoluble problems. ... 18

The dangers inherent in according the states an uncontrollable unilateral discretion to question and deny other states' ascription of nationality to their ships are manifold. It might lead to the treating on the high seas of ships of other states as stateless with all the consequences which attach to ships without nationality; it might permit some states arbitrarily to deprive other states of their hitherto universally recognized equal right to sail ships on the high seas; it might lead to the denial of the right of innocent passage through the territorial sea to such ships and the exclusion from access to internal waters and ports, and it would certainly encourage discrimination in international sea commerce. Observers who find analogies in the law about individuals for the law of ships must regard the creation of a new category of statelessness as highly ironical in an era marked by efforts to reduce, if not eliminate, statelessness of individuals. ${ }^{49}$ It seems pertinent here to quote statements made by responsible officials of two traditional maritime nations which have given their support to the "genuine link" concept and yet who could not fail to detect the hazards of this innovation. In an answer to the pressures exercised upon the Government of the United Kingdom to take some positive action against flags of

portance to the fact of a state's attributing its national character to the enterprise. 2 Rabel, Conflict of Laws 74-80 (1947) ; American Law Institute, Restatement, Conflict of Laws $\$ 197$ (1934); Gower, The Principles of Modern Company Law 62 (1954). The policies underlying these decisions we may appropriately invoke in support of our recommendation with respect to vessels.

The representatives of a business enterprise may, however, operate within the exclusive public order domains of many different states and more than one state may lawfully attribute its national character to the enterprise. The impacts of the peripatetic activities of the representatires of business may be felt in many different states and the factors which mas affect a rational allocation of competence among states for prescribing and applying policy to such activities may include many more items than the facts of attribution of national character. The policy relevance of different attributions of national character thus varies from problem to problem. Most importantly, few of the problems have much in common, policywise, with the problems of maintaining full access to, and shared enjoyment of, a common resource such as the oceans.

Note, further, the high degree of immunity that a state may confer upon a business entorprise by clothing it in a governmental corporation. Brandon, "Sovereign Immunity of Government Owned Corporations and Ships," 39 Cornell Law Q. 425 (1954).

484 Official Records 29.

19 In fairness, we mean only those observers with a certain sense of consistency. 
convenience, Lord Mancroft, explaining his government's standpoint on the subject, declared in the House of Lords :

I believe that the House is also well aware by now that there is no easy or quick solution to this threat. Because of the nature of the British merchant fleet, we have to be very careful lest any action taken by Her Majesty's Government may harm British shipping more than "Panlibhonco" owners. The British merchant fleet exists and prospers on the free exchange of shipping services. It is therefore most important that we should not take any action against flags of convenience which is any way discriminatory or restrictive, because in the long run that might, by a chain effect, lead to the placing of restrictions elsewhere on the operation of British ships. ${ }^{50}$

Mr. Pfeiffer, a delegate of the Federal Republic of Germany, warned the Geneva Conference:

If article 29 [now Article 5] were adopted as drafted, it was conceivable that in many cases ships could no longer be registered by states offering convenient conditions, owing to the lack of a genuine link between the state and the ship, but would also not qualify for registration in the state with which they had a genuine link, because of the strict conditions imposed. The regrettable result would be that the ship concerned would be condemned to statelessness by international law. ${ }^{51}$

Thus, instead of achieving its proclaimed goal, i.e., greater uniformity and stability, the concept of a genuine link as formulated in the convention would seem to be destined to bring about totally undesirable results : confusion, uncertainty, arbitrary unilateral action, and lack of harmony in the common enjoyment of the oceans.

\section{The Requirements of Rational Inquiry and Recommendation}

The full exposition of these multiple, dangerous misconceptions and the establishment of more rational perspectives must require comprehensive and realistic orientation in the interrelated processes of interaction, claim, and decision which constitute states' shared enjoyment of the oceans, and, through this orientation, the careful distinction of varying problems, relevant policies, and appropriate remedies. The controversies in which claims are made that the national character of a vessel is a factor relevant to decision will be seen to range from those in which the common interests of states in the shared use of the oceans are at stake in very high degree, such as with respect to events occurring upon the high seas or in contiguous zones, territorial seas, or internal waters, to those in which such common interests are at stake in only modest degree, such as with respect to claims arising from the mere presence of a valuable asset, the ship, within the domain of effective control of a territorial community. The projection of a rational general community policy with respect to these very different problems, including determination of the degree of conclusiveness which should be accorded states' attribution of national character to vessels, must, 50208 Parliamentary Debates, House of Lords 369 (March 20, 1958). 514 Official Records 11-12. 
accordingly, entail certain further more specific tasks : first, the clarification of the detailed policies relevant to each particular type of problem, in a manner designed to secure both the inclusive interests of states in the enjoyment of the oceans and their exclusive interests in their internal processes, and allocating that significance to states' attributions of national character to vessels which is most appropriate to this end; next, the study of past trends in decision, and of the factors affecting decision, with respect to the different types of problems, for the purpose of appraising the policy relevance of this experience for probable future conditions; and, finally, the recommendation of appropriate alternatives in principle and procedure for the future.

We begin by noting in broad outline the processes of interaction, claim and decision, and move then to the clarification of policies, the observation of past practices, and the making of certain recommendations.

\section{The Process of Interaction}

\section{Participants}

Every inhabitant of the globe is obviously a participant in interactions affected by the common enjoyment of the oceans and a beneficiary of their shared use. The interacting participants who have engaged in actual use of the oceans have included all states, coastal and land-locked, large and small, and countless individuals and private organizations who have achieved access by operating vessels upon which the states have conferred their national character. In every interaction upon the oceans the most siguificant fact is that the vessels by which the participants interact, if their interactions are lawful, are identified by their national character.

Among future participants we may anticipate international governmental organizations, making a direct use of the oceans by vessels to which they attribute an international character. ${ }^{52}$

\section{Objectives}

The most general objective of each participant has been, of course, to maximize its own values, and values sought by different participants have embraced the whole spectrum of human demand. The great diversity of the specific goals sought extends to every phase of all the various value processes, characteristic of contemporary communities, which we have elsewhere described in terms of power, wealth, skill, respect, well-being, enlightenment, rectitude and solidarity. ${ }^{53}$

52 The Geneva Conrention on the High Seas explicitly provides for such a possibility in Article 7, which reads:

"The provisions of the preceding articles do not prejudice the question of ships employed on the official service of an intergovernmental organization flying the flag of the organization."

s3 See, for illustration, MeDougal and Burke, "Crisis in the Law of the Sea: Community Perspectives Versus National Egoism," 67 Yale Law J. 539, at 569-570 (1958). 


\section{Situations}

The outstanding characteristic of situations in which interactions occur in shared exploitation of the oceans is that these situations embrace both areas upon the high seas, free from the exclusive public order of any particular state, and areas under varying degrees of exclusive control by coastal states.

The time element of interaction may also be important because of the prevalence of varying degrees of expectation of violence between two polar extremes of peace and war. Interactions on the oceans are, of course, inextricably interlinked with interactions on the land masses and have been the great channels of communication by which the territorial communities of the world have been lmit into a single global social community process. "On the oceans" quite obriously must be construed to include "over" and "under."

\section{Base Values}

The base values which the different participants engaging in the use of the oceans may bring to bear in support of their activities range over all the values at the disposal of such participants for all their purposes. The resources of the land masses of the world are at the disposal of participants for increasing the values they seek upon the oceans, just as the resources of the oceans are at their disposal for increasing the values they seek upon the land masses.

The unique base value employed upon the oceans is of course the ship. Because ships may be employed by or on behalf of all states, great and small, the oceans have been referred to as the "great equalizer." The success of some small states which, throughout history, have been able to capitalize upon their special geographical position, skills and enlightenment. bears eloquent witness to the importance of this rôle of the oceans.

\section{Strategies}

The strategies employed by participants to affect outcomes equally include all relevant instruments of policy: economic, diplomatic, ideological and military. As is necessary in a domain of shared competence, emphasis in strategy has been on peaceful, consensual modalities rather than upon coercive ones, and, through an elaborate structure of mutual tolerances and reciprocal deference, a highly co-ordinated process of co-operative enjoyment has been attained with the minimum of concentrated political power. The most distinguishing characteristic of this regime of mutual restraint has been unquestioned deference by states to their respective attributions of national character to vessels.

\section{Outcomes}

The immense production of values for all participants in the shared use of the oceans, as the argosies of many different states have plied the sea 
lanes of the globe, needs no elaborate documentation. States have been able to secure in high degree all the characteristic values of such territorial communities and especially the vast enhancement of their bases of power in such values as wealth, skill, respect and enlightenment. Individuals and private groups, identifying themselves with many different states, through attributions of national character to vessels, have been able to achieve their commercial and other value goals in similarly high degree.

\section{Effects}

The expanding consequences of these outcomes for the continuous benefit of all mankind are no less obvious. All peoples, even those who do not themselves directly engage in activities upon the oceans, gain from the maintenance of the oceans as the primary highways for the interchange of goods and services, from one end of the globe to the other, and as a vast reservoir of food and other resources.

\section{Conditions}

The most important of the conditions affecting this rich production of values has been the willingness of states to make the accommodations necessary to shared use and shared competence, such as are expressed, for example, in the "rules of the road" and in the deference to each other's attributions of national character to vessels. These accommodations have permitted, among other things, an economic division of labor and the employment of capital and skills in ways designed to promote the highest productivity. Freedom of access by all states, the employment of skilled personnel of all nationalities, the opportunity to experiment in national tax and fiscal structures, and many other factors, have operated to maintain initiative and the most intense co-operative activity on a global scale. ${ }^{54}$

\section{The Process of Claim}

In the course of the process of interaction by which peoples enjoy the shared use of the oceans, controversies continuously arise relating to agreements and deprivations occurring both in the activities upon the oceans and in the activities upon the land masses. The parties to these controversies commonly make claims in varying arenas of authority, both international and national, with respect to the lawfulness of the value changes effected by such agreements and deprivations. These claims embrace not only the parties' perspectives of the events precipitating controversy, but also their demands for specific redress and all the justifications, technical and policy, which they invoke in support of their demands. This process of claim may be briefly characterized in terms of the claimants, their objectives, the specific types of demands asserted, and the conditions which peculiarly affect their assertion.

For a more systematic statement of these conditioning factors see ibia. at 550 . 


\section{Claimants}

The claimants who invoke processes of authority include the whole gamut of participants in the world social process-most importantly, nation-states, private associations and individuals.

\section{Objectives}

The objective sought by the state-participants are, of course, to secure their inclusive interests in the shared use of the oceans and their exclusive interests in the value processes of their land masses and immediately adjacent waters. The objectives of the private participants are to protect their varying property, commereial and other interests.

The specific types of claims which states make against each other, both on their own account and on the account of the private participants, comprise a hierarchy of interrelated demands. These specific types of claims, like the controversies from which they originate, relate to the whole of the events comprised in the world social process, ranging from those immediately affecting the shared use of the oceans to those only indirectly affecting such shared use and primarily affecting the internal processes of states.

The claims with respect to events more directly affecting the shared use of the oceans include such various types of demand as follows: demands to attribute national character to vessels; the basic demands for free and unimpeded use of the oceans; demands primarily concerned with jurisdiction, that is, the prescription and application of authority to vessels and to events on board vessels; demands to protect vessels from unlawful assertions of authority by other states and demands relating to the criteria for identifying the national character of vessels.

The specific types of claims about events not directly affecting the shared use of the oceans embrace all of the activities with which private international law has historically concerned itself and may relate to any phase of any value process. In controversies presenting claims of this type the national character of a vessel may be but one factor among many in the context which are relevant to disposition of the claims. For inquiry into the different types of claims to ascertain the policy relevance of the na: tional character of vessels, and the importance of the conclusiveness of a state's attribution of national character, we propose a brealsdown under the following headings :

\section{Claims Reuating to Control over Ships}

A. Cluatms to attribute National character to SHIPS

B. CLAJMS TO PROTECT SHIPS TO WHICH NATIONAL CHARACTER HAS BEEN ATTRIBUTED AGAINST UNLAWFUL ASSERTIONS OF AUTHORITY BY OTEER STATES

C. CLAIMS TO CONTROL THE MOVEMENT AND ACTIVITIES OF SHIPS TO WHICH NATIONAL CHARACTER HAS BEEN ATTRIBUTED 
D. CLAIMS TO PRESCRIBE FOR DETERMINATION OF OWNERSHIP AMONG CONTENDING CLAIMIANTS

E. CLAIMS TO REQUISITION NATIONAL SHIPS OUTSIDE TERRITORIAL DOMAIN

II. Chaims to Access and Freedom of Navigation

A. CLAIMS TO ACCESS

1. Claims to Access to the High Seas

2. Claims to Access to Territorial Bases of Other States

3. Claims to Access to International Waterways under Special Regime

B. CLAIMS WITH RESPECT TO SECURING SHARED ENJOYMIENT OF FISHING ON THE HIGH SEAS

1. Claims Relating to Fishing in Areas of Shared Use and Competence

2. Claims Relating to Fishing in Areas of Exclusive Competence

C. CLAIMS WITH RESPECT TO SECURING SHARED USE FOR SUBMARINE CABLES AND PIPELINES

D. CLAIMS WTH RESPECT TO SEARED USE OF AIRSPACE ABOVE THE HIGH SEAS

III. Clatas with Respect to Events Directly Affecting Common EnJoYment of the High Seas

A. ClaAMS TO PROTECT MINIMAL ORDER

1. Claims against Other States for the Lawful Conduct of Ships and Aircraft to Which They Have Ascribed Their National Character

(a) Major violations of public order

(b) Lesser deprivations

2. Claims to Repress Piracy

3. Claims with Respect to Stateless Ships

4. Claims to Take Punitive Measures Against Ships Fraudulently Changing Flags on the High Seas

5. Claims to Prevent Use of Ships in Slave Trade

B. CLAIMS WITH RESPECT TO SECURING SAFE AND ORDERED NAVIGATION

1. Claims to Conform with Internationally Adopted Rules of the Road and Regulations for the Prevention of Collision at Sea

2. Claims to Conform with International Standards Concerning the Use of Signals and Maintenance of Communications

3. Claims with Respect to Construction, Equipment and Seaworthiness of Ships

4. Claims Relating to Adequate Manning and Competent Crew

5. Claims Relating to Assistance to Persons and Ships in Distress 
C. CLAIMS RELATING to CONTROL OF POLLUTION

1. Claims with Respect to Pollution of the High Seas and/or Airspace Above

(a) By discharge of oil from ships or pipelines

(b) From exploitation of the seabed and subsoil

(c) From the disposal of radio-active waste

(d) Resulting from any activities with radio-active materials or other harmful agents

D. CLAIMS TO TEMPORARY EXCLUSIVE USE IN NON-CONTIGUOUS AREAS OF THE HIGH SEAS AND AIRSPACE ABOVE

1. Claims to Exclude Temporarily Non-National Ships or Aireraft from Certain Delimited Portions of the Oceans for purposes of:

(a) Naval maneuvers

(b) Nuclear experiments of great importance to national security

(c) Experimentations relating to exploration of outer space

2. Claims to Compensation for Ships, Aireraft and Individuals Who Have Suffered Harm by Such Activities

IV. Cuains Relating to Events Occurring on Board Ship on the HigH Sras

A. ClaIMS RELATING TO PUBLIC ORDER OF SHIP

1. Claims Relating to the Discipline of the Crew

2. Claims Relating to Control of Passengers

B. CLAIMS RELATING TO EVENTS NOT AFFECTING PUBLIC ORDER OF SHIP

1. Claims with Respect to Deprivations

2. Claims with Respect to Agreements

3. Claims with Respect to Dispositive Acts : (a) Wills; (b) Gifts

4. Claims with Respect to Events Affecting Personal Status of Passengers and Crew: (a) Births; (b) Marriages; (c) Deaths

\section{Ciajms to Protect Coastal Interests}

\section{A. ClaIMS RELATING TO INTERNAL WATERS}

1. Claims to Control of Access

2. Claims to Control Passage through Internal Waters

3. Claims to Regulate Navigation of Ships

4. Claims Relating to Control over Ships

5. Claims to Apply Authority with Respect to Events Occurring on Board Ship

(a) Events affecting value processes beyond the ship

(b) Events only incidentally affecting value processes beyond the ship

6. Claims to Exclusive Exploitation of Natural Resources 
B. CLAIMS RELATING TO TERRITORIAL SEA

1. Claims to Deny Access

(a) Claims to deny access absolutely

(b) Claims to deny passage as non-innocent

2. Claims to Regulate Narigation of Ships

3. Claims Relating to Control of the Ship

4. Claims to Exercise Authority over Events Aboard Ship

(a) Events affecting value processes beyond the ship

(b) Events only incidentally affecting value processes beyond the ship

5. Claims to Deny Access to Non-National Aireraft

6. Claims to Exclusive Exploitation of Natural Resources

C. claims relating to contiguous zones

1. Traditional Claims: (a) Security; (b) Customs; (c) Revenue; (d) Health

2. Claims to Exclusive Access to Fisheries Beyond the Territorial Sea

3. Claims to Exclusive Exploitation of the Natural Resources of Continental Shelf and Other Submarine Areas: (a) Marine resources; (b) Mineral resources

D. Claims RELATING TO THE DELIMITATION OF BOUNDARIES

VI. Claims Relatiag to Seizure of Saips for Purposes of Civil JURISDICTION

VII. Claims with Respect to Events Primariut affecting Value Processes within Territorial Commonities aNd Not Directly Related to The Enjoyment of the High Seas

VIII. Clamis Relating to Modalities of Proof of the National, Character of Vessels

A. ClatMS WITH RESPECT to REgistration

1. State Vessels

2. Private Vessels

B. CLATMS WITH RESPECT TO DOCUMENTATION

C. CLAIMS WITH RESPECT TO FLAG

D. CLAIMS WITH RESPECT TO NAME OF THE VESSEL

E. CLATMS WITH RESPECT TO "GENUINE LINK"

\section{Conditions}

The conditions which affect the making of these claims and the response to such claims include all of the important variables of the contemporary world arena. The lack of centralized authority capable of monopolizing force in support of community authority is, of course, the most distinguish- 
ing characteristic of this arena. Nevertheless, the potentialities in unorganized sanctioning by reciprocity and retaliation are so formidable that claimants may enjoy moderate expectation that the processes of authoritative decision will afford them a reasonable protection.

\section{The Process of Decision}

The process of authoritative decision, established by the general community of states for the resolution of controversies arising from the shared use of the maritime domain, exhibits in a very high degree the primitive, yet complex, development of organizational, jurisdictional and procedural structures and techniques generally characteristic of international law. Though there is frequent explicit multilateral prescription of community policies, most decisions in application are taken by states acting unilaterally. There is unfortunately no procedure or sanction for compelling states to submit to third-party review of their unilateral decisions. Incentives for the clarification of policies in the common interest and an important check upon abuses of authority may, however, be found in the practical necessities of everyday commerce and the inherent requirements of a decentralized system of shared competence. The main outlines of this system may be observed summarily under the headings of officials, objectives, strategies, outcomes and conditions. 55

\section{Officials}

The most important authoritative decision-makers are, of course, state officials. The dual rôle of these officials, who on some occasions are mere claimants to authority, and on other occasions the authorized representatives of the general community applying authority to the claims of others, does not necessarily mean that they are inherently unable to identify a common interest and incapable of taking the decisions designed to serve that interest. It is indeed this dual rôle which requires the clarification of common interest and the basing of all claims upon the promise of reciprocity.

Although not participating directly in formal decision, many private pressure groups, such as, e.g., seamen's unions and shipowners' organizations, exercise a most significant influence upon the actual course of deeision. The fact that some of these groups have achieved more effective international organization than has been achieved upon the level of government is not without policy consequences. The historic rôle of private associations performing functions indispensable to maritime commerce, such as classification societies and insurance companies, needs no new exposition.

An ever-increasing rôle in relevant decision is being taken by international officials, such as those in the United Nations, International Labor Organization, Intergovernmental Maritime Consultative Organization, Food and Agriculture Organization, International Telecommunications Union,

55 Gidel's three-volume work, Le Droit International Publie de la Mer (1932-1934), is still the most authoritative treatment of this process of decision; see also, Colombos, International Law of the Sea (3d ed., 1954); Potter, Freedom of the Sea (1924). 
International Civil Aviation Organization, World Health Organization, World Meteorological Organization, international courts, and arbitral tribunals. The intelligence and recommending functions of these intergovernmental organizations are of particular importance, and new proposals are being made to extend the rôle of compulsory adjudication and arbitration in the resolution of controversies.

\section{Objectives}

The more general objectives sought by the community of states in its establishment of authoritative decision-makers for these controversies may be conveniently categorized, beginning with those directly related to the shared enjoyment of the oceans, and moving to others not so directly related, as follows:

(a) to secure and preserve equality of access to the common resource of the aceans;

(b) to maintain the minimal public order at sea by:

(1) preventing unauthorized violence,

(2) preventing controversies from arising;

(c) to protect the inclusive and exclusive interests of states and to promote the most economic accommodation of these interests in the shared use of the oceans;

(d) to promote efficiency in common enjoyment;

(e) to conserve exhaustible resources of the oceans (such as fish, minerals) ;

(f) to authorize states to protect and fulfill basic goal values in the internal processes of their territorial communities.

An overriding objective, particularly characteristic of public and private international law, is, of course, to attain that stability in the expectations of peoples necessary to encourage transactions across state lines and between states, and yet at the same time to promote beneficial change.

\section{Strategies}

In decision with respect to these controversies, as elsewhere in international law, authoritative decision-makers engage in a variety of policy functions, including prescribing, intelligence-serving, recommending, invoking, applying, appraising and terminating.

The prescribing function has been performed in greatest measure in what is commonly called development by custom in generalizing inferences from past uniformities in practice. In modern times explicit agreements have become more important, though these on occasion largely embody historic practice.

The identification of parties authorized to invoke the processes of authority for the protection of ships against abuses of authority has been effected in universal practice by making conclusive the competence of states to attribute national character to vessels. This competence of the 
state of national character has not, of course, precluded the concurrent competence of other parties, as authorized by various principles of public and private international law.

The function of applying basic jurisdictional and procedural policies has been largely performed in day-to-day practice of foreign offices and other national agencies. For many problems crucial to the shared enjoyment of the oceans, competence and responsibility for the direct application of coercion to ships has been accorded to and imposed upon the state attributing its national character to a vessel. For other problems, not so crucial-and inrolving more the exclusive interests of states-states other than a state of national character have been authorized directly to apply coercion to ships.

In addition to government officials, pressure groups from both labor and the shipping interests have begun to play important rôles in the less formalized but no less significant functions of intelligence-serving, recommending and appraising.

Explicit agreement, not always well advised, ${ }^{56}$ is on oceasion employed for the purpose of terminating traditional practice.

\section{Outcomes}

The historic outcomes of the process of decision, honoring the conclusiveness of states' attributions of national character to ships when necessary, and according such conclusive attributions appropriate significance on other problems, have in very considerable measure achieved protection of equal access to the oceans, the establishment of a satisfactory minimal order and a reasonable accommodation of the inclusive and exclusive interests of states. Documentation of this accomplishment will be offered below in describing the trend of decisions.

\section{Conditions}

The conditions affecting the process of decision embrace all the interacting variables of the world arena. In recent times these variables have been undergoing profound change.

The world has divided into hostile camps projecting contending systems of public order. Many new states have emerged and some of these, as well as older states, which should be more sensitive to their responsibilities, are demanding to be "more equal than others" in access to sharable and strategic resources. 57 Increasing socialization in many states has exacerbated the difficulties of international co-operation. Expanding scientific knowledge and improving technology have vastly enhanced potentialities for both production and destruction. The resources of outer space may in the future be in competition with those of the oceans. Burgeoning populations combined with these technological developments have intensified the inter-

56 Such as the introduction of the "genuine link" requirement in the Geneva Con. vention on the High Seas.

57 It will be recalled that comparable demands were made by some of the protagonists in "Animal Farm." 
dependences of peoples. Capital investments, both state and private, across national boundaries and the movement of goods and services have multiplied in many ways. The effective internationalization of pressure groups, outdistancing that of government, has magnified the difficulties of establishing and maintaining a general community policy.

\section{The Clarification of General Policies: The Common Interest in the Conclustveness of Attributions of National Character}

In seeking more systematic and detailed clarification of a rational general community policy concerning the nationality of ships-a policy to which a proponent of a world public order of freedom, security and abundance may unreservedly commit himself-we begin with the axiom, until recent times almost universally honored with respect to this problem, that jurisdictional and procedural principles and techniques should be shaped entirely to serve the more basic, substantive policies which are their excuse for being. ${ }^{58}$ The application of this axiom in necessary detail requires that we be quite exact about the basic, substantive policies at stake in events which include the national character of ships among policy-relevant factors.

In our deseription above of processes of interaction, claim, and decision we identified certain inclusive interests and certain exclusive interests of all states. Te observed that all states have asserted claims to equal access to, and enjoyment of, the oceans and to a shared competence in the processes of authoritative decision, by which such equality in access and enjoyment is protected and regulated. The expectation is common, and undoubtedly realistic, that the shared competence in decision-making is indispensable to the shared enjoyment in use. Hence, it may be said that all states share an inclusive interest in both common enjoyment and shared competence with respect to the oceans. In polar extreme to this inclusivity of interest, we observed also that all states assert claims to protect their internal community processes from harms from the sea by exclusive prescription and application of authority. It need not be doubted that states' expectations of potential harms from the sea are realistic, and, hence, that all states have an exclusive interest in appropriate protection. Similarly, all states make claim to preseribe and apply authority to various events, oceurring in the world social process, which substantially affect their internal community processes, even though these events do not occur or have their effects entirely within their own territorial boundaries, and all states have a common interest in the maintenance of a process of authoritative decision with respect to such erents which protects both their exclusive and inclusive interests. From the most comprehensive perspective, it may be added further that all states share an inclusive interest in the establishment of standards of safety, labor and competition, for activities occurring upon the oceans as well as upon the land masses, which will promote the highest well-being and the greatest production of goods and services for all mankind. It is easily demonstrated, however, that procedural principles re-

5. U.N. Secretariat, Memorandum on the Regime of the High Seas 10, U.N. Doc. A/CN. 4/32 (1950); MeDougal and Burke, loc. cit, note 53, at 559 . 
lating to the nationality of ships bear upon, and admit of manipulation for securing, these different policies in very different ways.

For securing the common interest of all states in shared enjoyment of, and competence over, the oceans, the procedural principle that one state's attribution of national character to a vessel is conclusive upon other states appears indispensable. It is by a vessel that a state asserts both its claim to enjoyment and its claim to participate in shared competence. It is by control of the vessel that enjoyment is secured, and by competence to prescribe and apply authority that control is secured. Such control and assertion of authority can be made secure in the present disorganized world arena only if a state which has attributed its national character to a vessel is accorded unquestioned competence to protect the vessel against abuses of authority by other states. The state which is denied such competence is denied its share in authority, and in the absence of centralized, international institutions, with effective control over abuses of authority, it has no other lawful recourse. An arena in which such denials became common practice could not be expected long to remain an arena of shared authority. In examining below the trends in past practice with respect to problems in which the basic community policies of shared enjoyment and shared competence are most directly at stake, we will indicate in more detail the importance to these problems of the high conclusiveness of states' attributions of national character.

For honoring an appropriate authority in states for the protection of their exclusive interests in their internal community processes, whether these interests relate to preclusion of harm from the sea or more generally to the regulation of the impact of events occurring in part elsewhere, it is not necessary that the conclusiveness of a state's attribution of national character to vessels should be put in question. For problems in which the lawfulness of such assertions of authority by states is the relevant issue, the fact that another state has attributed its national character to a vessel is but one factor among many which may be significant for policy, and it may not be the most decisive factor. For violations of its lawful regulations with respect to its internal waters, territorial sea, and contiguous zone, a state may, of course, apply its authority to vessels having the national character of other states, else its regulations would be pointless. Whether the regulations are lawful, as, for example, with regard to contiguous zones, may require nice calculations of "reasonableness" in a balance of the interests sought to be protected, the interests of others subjected to interference, the modalities of interference, and so on, but the nationality of the ships to which authority is applied certainly can be no more than a relevant factor in determining appropriate balance. In its prescriptions and applications of authority for events having substantial effects upon its internal processes, though not occurring entirely within or having effects entirely within its boundaries, a state may, again, quite lawfully apply its authority to ships to which other states have attributed national character, just as it may to individuals and corporations bearing the nationality of other states. The most fundamental policies at stake are a reasonable 
security in transactions and "comparative justice" by the standards of mature systems of law. ${ }^{59}$ For determining these policies in particular instances, the nationality of a vessel may be a relevant, but not necessarily conclusive, factor. The important point is that decisions, in cases of this type, that the national character of a vessel is not the most significant factor in determining decision need not be over-generalized as holdings that the "conclusiveness" of national character is denied. The justifiable application of authority to vessels, irrespective of their nationality, is obviously quite different from denial of the competence of a state to attribute its national character to a vessel. Policies making attributions of national character conclusive for purposes of protecting shared competence over the oceans need not be extrapolated into policies demanding immunity from authority for all purposes; conversely, decisions denying the policy significance of national character on problems in which shared competence over the oceans is not at stake need not be exaggerated into precedents for confusing such problems. The confusion of saying that "national character is irrelevant" with saying that the "competence of a state to attribute national character is denied" arises from simple failure to distinguish different types of problems and uniquely relevant policies.

It may require emphasis, so much confusion abounds in the books, that the factor which may be significant or conclusive in all these cases-the factor whose policy significance we seek to appraise-is the act, the authoritative decision, of a state in conferring its national character upon a vessel. Theoretically, this act could be evidenced in many different ways. The most common way is, of course, by registration-with incidental aid from documentation, flags, and names-and this is the way which would appear most compatible with general community policies of security, dispatch, and notice to other states and parties. The policy significance of registration, documentation, flags, and so on, despite elaborate and painful efforts to establish for them an independent significance, is, however, merely ancillary. Their importauce and only importance is as modalities of dependable or undependable proof of the primary act of state attribution. Note may be taken further, in passing, that "genuine link," whatever content may be poured into the words, can add nothing to the security, dispateh, and public notice which registration affords. Justification for any requirement of "genuine link" must be found, if it can be found, not in the needs of proof of state decision to attribute national character to vessels, but in policies which override and limit that decision. The task of securing the inclusive interests of all states in the establishment and maintenance of standards of labor and competition, on a world-wide basis, which will promote the highest well-being and greatest production of goods and services for all mankind, is clearly a problem quite different in nature and magnitude from those hitherto considered. It may be that for the better secur-

s9 Intema, "The Objectives of Private International Law," 35 Canadian Bar Rev. 721, 735 (1957); Katzenbach, "Conflicts on an Unruly Horse: Reciprocal Claims and Tolerances in Interstate and International Law," 65 Yale Law J. 1087, 1107-1109 (1956). 
ing of these interests it has, or will, become necessary to make states' access to the oceans conditional upon fulfillment of specified standards. A very heavy burden of proof is, however, incumbent upon those who urge that the conferring upon states of unilateral competence to question each other's attribution of national character to ships is the most economic mode of giving sanction to these standards. Such a mode of administration might not only fail to achieve the new objectives but cause immeasurable damage to already established common values. States willing to accept the new standards of substantive policy might also be willing to accept more rational measures in implementation.

The search for a content for "genuine link," expressing a generalizable policy for the whole community of states, may, we note finally, find little substance or comfort in the national policies which states have applied internally to condition their attribution of national character to vessels. The most common of these policies relate to ownership by nationals and the nationality of the crew or the commanding officers, and, in lesser degree, to construction within the country. No one of these criteria would appear to express a policy designed to secure a general community interest. On the contrary, it is clear that they express unsharable exclusive interests. Any international requirement which conditioned the attribution of national character upon ownership by national individuals would sorely limit countries with little accumulated capital in favor of countries with large accumulations. The international restriction of competence to attribute national character to vessels manned only by the individual nationals of the same state might promote, from global perspective, a most uneconomic division of labor and would further impose severe limits upon the free movement of human beings, wholly incompatible with contemporary conceptions of human rights. Any international limitation of national character to vessels constructed within a country would have similar unfortunate effects and impose equally onerous burdens upon the newly emerging states. All the traditional criteria which states have employed in their exclusive national interests, whether required singly or in combination, would thus, if transposed into international policy, impose grave deprivations upon the free choices of individuals in movement, as well as intolerable limits upon states' power to employ ships and enjoy the oceans as bases of power.

More detailed policies relating to each specific category of claim will, for convenience, be stated at the beginning of the discussion pertaining to such category and will be followed with a brief summary of past decisions confirming these policies.

\section{Trend of Past Decisions and Conditioning Factors}

I. CLAIMS RELATING TO CONTROL OVER SHIPS

\section{A. Claims to Attribute National Character to Ships}

The basic community policy here is that of securing the most productive shared use of the oceans. The historic practice by which all states have 
been able to make effective claims to share in the use of the oceans has been by sending forth both state and private ships to which they have attributed their national character. ${ }^{60}$ It has long been acepted under the doctrine of sovereign immunity that one state cannot question the national character of state ships, and the procedural policy with respect to other ships which seems most compatible with securing the basic community policy would appear to be that of making states' attributions of national character conclusive, whatever the eriteria of their choice. ${ }^{61}$ The one necessary limit upon the discretion of states, and a limit which appears universally accepted, is that, once a state has conferred its national character upon a vessel, other states may not confer their national character as long as the original national character remains unchanged.

Uniform practice on both international and national levels has long fully substantiated the policy conclusions outlined above. ${ }^{62}$ In the famous case of Muscat Dhows, involving the contention advanced by Great Britain that France was restricted by treaty in granting its national character to vessels belonging to the subjects of the Sultan of Museat, the Permanent Court of Arbitration at The Hague declared that "it belongs to every sovereign to decide to whom he will accord the right to fly his flag and to preseribe the rules governing such grants," 63 and concluded that "France was entitled to authorize vessels belonging to subjects of His Highness the Sultan of Muscat to fly the French flag, only bound by her own legislation and administrative rules. ..." S4 Similar deference for the conclusiveness of a state's attribution of national character has been exhibited in a number of other cases. Two of the more famous cases in which this deference was accorded under the most extreme circumstances are the cases of The Virginius ${ }^{65}$ and The Schooner Exchange v. IIcFaddon. ${ }^{66}$

The Tirginius, a vessel registered in the United States and flying the American flag, while sailing toward Cuba, was seized by a Spanish warship

so The degree of consensus on this is evident in the emphasis on national character in Gidel:

"L'attribution aux navires de mer d'une identité et d'une nationalité est le corollaire Iu principe du libre usage de la hante mer. Grâce à cette réglementation . . les navires peuvent être surveillés, contrôlés: les abus que pourrait entraîner le principe de lia liberté des mers se trouvent limités si l'on n'admet à l'usage de ces mers que les navires pouvant justifier d'ume nationalité." 1 Gidel, Le Droit International de la Mier 73 (1932).

o1 "This is the undisputed right of each State: to set up such prerequisites for the assumption of its nationality as its concept of national welfare dictates. There are apparently no limits on the positive exactions of States in this regard. Theoretically, a State may, by the harshness of its rules, prevent any vessel from sailing under its flag." Rienow, The Test of the Nationality of a Merchant Vessel 214 (1937).

62 This historical tradition has been described by a noted French commentator in these words: " . . . en ce qui concerne la nationalité des navires, le droit pour l'État de la conférer est affirmé depuis longtemps avec une particulière netteté." Cavaré, Le Droit International Public Positif 231 (1951).

6s The Muscat Dhows Case (France and Great Britain), Award of the Tribunal, The Hague, Aug. 8, 1905. Scott, Hague Court Reports 95, 96 (1916).

ot Ibid. at 99 .

os 2 Moore, Digest of International Law 895 (1906).

*6 11 U.S. (7 Cranch) 116 (1812). 
on the high seas and taken into a Cuban port. In explaining this seizure and the subsequent execution of a number of crewmen and passengers, Spain claimed that the vessel was engaged in aiding insurrection in Cuba and that its American national character was fraudulently obtained, the latter charge being based on ownership of the Virginius by Spanish nationals. In the course of the dispute President Grant asserted that, even if the Virginius had fraudulently obtained its registry, "proceedings should be instituted in [American] courts for the punishment of the offense committed against the United States." '6r Secretary of State Fish, in a note to Spanish authorities, further elaborated:

The shipping laws of the United States are municipal regulations which it prescribes for itself ... and the administration of which it intrusts to its own officers. It judges of the requirements and of the formalities to be observed to give its national character to private trading-vessels, and reserves to itself the punishment of evasions or omissions of those requirements or formalities. ${ }^{68}$

The Virginius was eventually restored to the United States, even though the latter admitted that the vessel obtained its American national character by fraud.

Though the decision in The Schooner Exchange case was made to turn on the immunity of a foreign "public armed vessel," the fundamental policy of not questioning the national character of a vessel was honored under the most extraordinary circumstances. ${ }^{69}$ The vessel in dispute came into Philadelphia harbor under the flag of the French sovereign and was there libeled by two American citizens, elaiming ownership of the vessel of which they were "forcibly and violently" deprived earlier when it was seized at sea by the French. ${ }^{70}$ The significance of the decision in this case

67 Special Message to Congress of Jan. 5, 1874. 2 Moore, Digest of International Law 901 (1906).

68 Rienow, op. cit. note 61 above, at 17, quoting from 2 Foreign Relations 1207-1208 (1875-1876).

69 The Court could not, of course, have reached the question of immunity if it had not accepted the French nationality of the vessel. Counsel for libelants " admitted that the commission, the flag, and the possession were sufficient evidence of the public character of the ressel." 11 U. S. (7 Cranch) 116, 121 (1812).

The necessities of minimal order certainly require that states honor each other's authoritative attribution of nationality to state vessels. As we see in The Schooner Exchange $v$. McFaddon, mutual deference, in the interests of harmonious intercourse, may be carried to the extreme of conferring upon state vessels complete immunity from local jurisdiction.

Complete immunity from the jurisdiction of other states, questioned even with respert to state vessels today, obviously is neither necessary nor desirable for non-state ships. The same policies which require unquestioned mutual deference to attributions of na. tional character to state ships would appear, however, to be equally relevant with respect to non-state ships, especially in days when state and non-state ships increasingly compete for the same world trade.

7o Chief Justice Marshall apparently had little doubt about the truth of the claims of the libelants:

"In the present state of the evidence and proceedings, the Exchange must be considered as a vessel, which was the property of the libellants, whose claim is repelled by the fact, that she is now a national armed ressel, commissioned by, and in the service of the Emperor of France.", Ibid. at 146. 
lies in the fact that the Supreme Court of the United States, in dismissing the complaint and refusing to investigate the rights and wrongs of the parties, did not question the French nationality of the ship, despite the fact that France had forcibly taken the ressel from its American owners.

A more recent instance in which the Supreme Court of the United States has reaffirmed the finality of a state's attribution of national character to a ressel is Lauritzen v. Larsen. There, Mr. Justice Jackson expressed relerant policy with utmost clarity:

... Each state under international law may determine for itself the conditions on which it will grant its nationality to a merchant ship, thereby accepting responsibility for it and acquiring authority over it. Nationality is evidenced to the world by the ship's papers and its flag. The United States has firmly and successfully maintained that the regularity and validity of a registration can be questioned only by the registering state. ${ }^{71}$

Further cogent indication of the universal acceptance of these policies is to be found in the singular uniformity of relevant treaty provisions for the past hundred years. Thus Article II of a treaty concluded in 1851 between Great Britain and the Kingdom of Sardinia reads :

All vessels which, according to the laws of Great Britain are to be deemed British ressels; and all vessels which, according to the law of the Kingdom of Sardinia, are to be deemed Sardinian vessels, shall for the purposes of this Convention ... be deemed British vessels and Sardinian vessels respectively. ${ }^{72}$

More than a century later, in the Treaty of Friendship, Commerce and Navigation between the United States and The Netherlands, concluded on March 27, 1956, the corresponding provision is as follows :

Vessels under the flag of either Party, and carrying the papers required by its law in proof of nationality, shall be deemed to be vessels of that Party both on the high seas and within ports, places and waters of the other Party. ${ }^{73}$

The unanimity among commentators may be illustrated by a single quotation from Rienow in his comprehensive monograph:

Each State determines for itself what ships it will regard as its own, but it eannot, of course, impinge upon the prior rights of other States. If a vessel already has a nationality, another State is not free to impose its nationality upon it. If the State to which a vessel belongs refuses to release it, no other State may admit it to its merchant marine. Beyond this, a State is free to encourage application for its nationality by maintaining liberal rules. No matter how lenient or harsh its conditions may be, once a State has denoted that these con-

21345 U. S. 571, at 584 (1953); digested in 47 A.J.I.工. 711 (1953). The principal issue in this case concerned the application of the Jones Act to claims by a Danish seaman who was injured in the course of his employment upon a Danish ship in Havana harbor. 72 Rienow, op. cit. note 61 above, at 19 .

${ }^{73}$ Art. XIX, 8 U. S. Treaties and Other International Agreements 2043; T.I.A.S., No. 3942. For a more detailed exposition of the relevant $U$. S. practice, see Walker, "Modern Treaties of Friendship, Commerce and Navigation," 42 Minn. Law Rev. 805 (1958). 
ditions have been met to its satisfaction through the medium of an official document, the nationality is impressed upon the vessel. ${ }^{74}$

\section{B. Claims to Protect Ships to Which National Character Has Been At- tributed against Unlawful Assertions of Authority by Other States}

The most important policy here, in implementing basic community policies about shared use and competence, is that of maintaining the effectiveness of the whole process of decision by which shared use and competence are secured. The claim to protect vessels, like claims to protect other forms of wealth and human beings, may be asserted through many different procedures, including: (a) diplomatic representation between foreign offices; (b) claims to and by consular authorities; (c) claims before the United Nations and other intergovernmental bodies such as I.M.C.O., I.L.O., and the like; (d) suits in international courts and arbitral tribunals; (e) claims in national courts and administrative agencies; and (f) the application of coercion by self-help in self-defense. It is not without reason that the community has made arailable so many different procedures to secure the purposes of protection. The competence to protect rights is, of course, indispensable to the enjoyment of the substance of rights, and since the competence of states to attribute national character to ships can in fact be questioned in relation to any particular problem, the competence to protect is indispensable with respect to every problem.

In the absence of prompt and effective compulsory international review of unilateral challenges to competence, it would be intolerable to submit the substance of states' rights to the enjoyment of the oceans to quibbles over ill-defined procedural eriteria. In view of the compelling nature of these policies it is not a little surprising to find that the one major, and only recent, publication dealing with this problem takes a position in flat contravention of these policies. Thus, Mr. Watts, in an article distinguished, inter alia, by an ambiguous use of the word "protection," and recommending ownership as "the criterion for protection," writes:

But internationally protection should not have a unilateral basis, for it is of necessity of inter-state concern : the protection-link should be objective, and such that it is compatible with the doctrine that a State in presenting an international claim is doing so in respect of damage to itself. ${ }^{75}$

74 Rienow, op. cit. note 61 above, at 218-219. The opening lines in Article 5 of the 1958 Convention on the High Seas read: "Each State shall fix the conditions for the grant of its nationality to ships, for the registration of ships in its territory, and for the right to fly its flag. Ships have the nationality of the State whose flag they are entitled to fly." The first sentence could conceivably be interpreted to incorporate historic policy with respect to the conclusiveness of the attribution of nationality and to preserve registration as the best evidence of that attribution. The second sentence, however, appears to reject registration as conclusive evidence of nationality, and the sentence which immediately follows introduces the requirement of genuine link. Further consideration is giren to genuine link below, p. 104 et seq.

75 Watts, "The Protection of Merchant Ships," 33 Brit. Yr. Bk. Int. Law 52, 66 (1957), citing as a prime example the Nottebohm decision. The interests which states are protecting are their inclusive interests in the common enjoyment of the oceans. It is fantastic to suggest, as $\mathrm{Mr}$. Watts does, that, while states have jurisdiction over their 
The act of a state in attributing its national character to a vessel is, of course, a unilateral act, as are most of the acts with which international law is concerned. But the policies behind the long-established practice that states so attributing their nationality to a vessel have competence under international law to protect the vessel are international policies expressing a common interest. Certainly, when a state seeks protection against deprivations imposed upon vessels to which it has attributed its national character, it is seeking redress for injury to its interests-interests which it shares with all other states who demand equal access to, and enjoyment of, the oceans.

The practice of states provides abundant and convincing evidence of the traditionally honored competence of every state to extend its protection to ships which bear its national character, irrespective of the nationality of the owners or any other possible relation between the ship and some state other than that of national character. The same practice shows that the conclusive factor for determining the exercise of protection against allegedly unlawful assertions of authority by other states is the fact of the national character of the ship. ${ }^{i 6}$ It will have been noted that two of the cases cited in the previous section involved controversies where protection was invoked. It should, however, be emphasized that in the case of The Virginius Spain recognized the right of the United States to intervene on behalf of the Virginius, even though the vessel was owned by Spanish nationals and had procured American registration by fraud. President Grant asserted the competence of the United States to extend its protection to the Virginius most forcefully:

When, therefore, she left the port of Kingston ... under the flag of the United States, she would appear to have had, as against all powers except the United States, the right to fly that flag, and to claim its protection, as enjoyed by all regularly documented vessels registered as part of our commercial marine. ${ }^{77}$

ships, they lave no right to protect them. Protection is, of course, of the most inelusive concern, inclusive concern for the protection of both the inclusive and exclusive interests of states. One principal purpose of a state's making attribution of national character to a vessel is to preclude other states from unauthorized assertions of authority for exclusire reasons.

76 Ripert, for example, states: "La nationalité du navire détermine les autorités compétentes pour exercer sur ce navire la surveillance et la protection." 1 Ripert, Droit Maritine 322 (4th ed., 1950).

With respect to aireraft, see Kamminga, The Aircraft Commander in Commercial Air Transportation 30-31 (1953). Kamminga writes: "An aircraft used for international transportation must be under the control of a State, which will see to it that the aireraft in question fulfills its obligations while in other States; this task devolres upon the State of origin of the aircraft. At the same time, however, this State naturally acts as protector of the rights of the aircraft concerned." Ibid. at 30. "Nationality is therefore of importance for the aircraft commander because it means that all over the world he is subject to the control of the State where his aircraft is registered, and also because he can count on protection by this State if the rights granted to his aircraft are infringed." Ibid. at 31.

772 Moore, Digest of International Law 900 (1906). 
Hence the mere fact of registration, although fraudulent, was considered sufficient to provide protection for the Virginius, even against the state whose nationals owned it.

The decision in The I'm Alone ${ }^{\text {is }}$ controversy between Canada and the United States is another unequivocal example of protection based almost exclusively upon the fact of the attribution of national character to that vessel. The I'm Alone was a vessel registered in Canada which engaged in smuggling liquor, in violation of the United States law, from British Honduras to certain points off the coast of Louisiana. On March 22, 1929, the I'm Alone was sunk on the high seas in the Gulf of Mexico by the American revenue cutter Dexter. The Commissioners appointed to decide upon the Canadian claim for compensation found the vessel "de facto owned, controlled, and, at the critical times, managed and her movements directed and her cargo dealt with and disposed of" by United States citizens. ${ }^{79}$ Notwithstanding these overwhelming links between the I' $m$ Alone and the United States, the Commissioners held the act of sinking the vessel "unlawful" and ordered the United States to apologize and pay" the Canadian Government $\$ 25,000$ "in respect of the wrong." 80

The confusion encountered in works of commentators with respect to protection is on occasion due to a confusion between the appropriate bases of protection and the indices of such bases. The commentators who see as the bases of protection in a given case the ownership, the flag or the registration of a vessel, clearly ignore the more important base: the act of the state in attributing its national character to a ship.

Emphasis upon the unquestioned competence of the state of national character to protect its vessels need not, however, be construed to mean that other states may not be competent to protect their varying interests in such vessels. Concurrent competence to protect by reason of ownership of a national is a well-established practice in international law, and there are no overriding reasons to dispense with it with respect to ships, provided, of course, that the interests of the state whose national character the vessel possesses be accorded adequate safeguards. In this connection, Mr. Rienow correctly observes:

Yet the right to protect ship property is an imperfect one, due to the special nature and qualities of ships. It can be made effective so long as it does not conflict with the control which the State to which the vessel legally belongs is, under international law, permitted to effect and does, in fact effect. ${ }^{81}$

78 (1933), 29 A.J.I.L. 326 (1935); 3 Rep. Int. Arb. Awards 1611 (1949).

79 Ibid. at 1618.

$80 \mathrm{In}$ his effort to replace nationality as a basis for protection of ships, Mr. Watts, understandably enough, finds the decision in the $I$ 'm alone case embarrassing. Ho therefore offers the following explanation of the "paradox": ". . the Claims Commission, invested with jurisdiction over any claims in respect of a 'British vessel' for compensation, took jurisdiction, thus considering the $I^{\prime} m$ Alone a British vessel for jurisdictional purposes, but held the $I$ ' $m$ Alone not to be a British vessel for purposes of protection." Watts, loc. cit. note 75 above, at 67 .

81Rienow, op. cit. note 61 above, at 104-105. 
C. Clains to Control the MLvement and Activities of Ships to Which $\mathrm{Na}$ tional Character Has Been Attributed

It would appear indispensable for the maintenance of public order upon the oceans, most noticeably in times of armed conflict, that some state have control of the movements and activities of a ship; and it would appear no less indispensable, to secure the equal rights of states, that, within limits imposed by international law, each state be given control of the ships to which it has attributed its national character, and that this right be honored and made effective by officials of other states. It is of course unquestioned practice that the state which is responsible for a ship's conformity with international law has a competence equal to its responsibility and may control the movement and activities of its ships as its interpretation of community obligations and its national policies require. This competence is so unquestioned that one will search in vain equally for conventions giving it superfluous reiteration as for those denying it. This unchallenged prerogative of the state of national character comes most often to attention in time of national emergency or war, as the examples below demonstrate.

Thus, in the case of Furness, Withy \& Co. v. Rederiaktiebolaget Banco, ${ }^{82}$ the Zamora, a ship of Swedish nationality, was chartered in 1916 to an English company for voyages between ports in various parts of the world. While the vessel was at Cardiff her owners refused to continue with their obligations on the ground that, under Swedish emergency legislation, vessels of Swedish registry were not allowed to trade outside Sweden. In a suit against the owners of the Zamora, the British court dismissed the complaint, giving full effect to the decree of the state whose national character the vessel possessed. In both world wars a number of neutral states issued decrees determining the areas where ships of their national character were allowed to navigate. Thus, for example, Section 3 of the Joint Resolution of Congress, approved November 4, 1939, authorized the President of the United States to define combat areas and to make it unlawful "for any eitizen of the United States or any American vessel to proceed into or through any such combat area." 83 For violations of these restrictions heavy penalties were provided. Similarly, Lord McNair, explaining the British practice, observed that the "Crown by prerogative may at any time order its subjects, and British merchant ships, to return to this country." 84 Furthermore, as noted by another commentator, a state "may suspend entirely the commercial intercourse of its vessels with another State, or all of them." 85

\section{Claims to Prescribe for Determination of Ownership among Contend- ing Claimants}

Stability of expectations about the ownership of ships, whether state or private, is, of course, indispensable to stability in arrangement with respect

82 [1917] 2 K.B. 873.

83 See 34 A.J.I.L. Supp. 162 et seq. (1940).

8* McNair, "Problems Connected with the Position of the Merchant Vessel in Private International Law, with Particular Reference to the Power of Requisition," 31 Grotius Society Transactions 30, 36 (1946). 85 Rienow, op. cit. note 61 above, at 4. 
to the use of the ships. If the ownership of vessels, which ply the ports of the world, changed like a sailor's love with each port, capital would have little attachment for ships. It has come to be expected that in the course of their operations ships may become subject to certain special liens, and indeed this is the principal meaning of the metaphoric personification of ships, but the subjection to these liens is in accordance with certain highly crystallized and internationalized principles of admiralty and international law.

The assumption upon which all states act is that the state of national character determines ownership. Thus, the Brussels Convention of 1926 relating to Maritime Liens and Mortgages provided that

Mortgages, hypothecations, and other similar charges upon vessels, duly effected in accordance with the law of the contracting State to which the vessel belongs, and registered in a public register either at the port of the vessel's registry or at a central office, shall be regarded as valid and respected in all the other contracting countries.88

It has been the practice of major maritime states to enact national legislation regulating in detail ownership claims in respect to ships, anil un one appears to question the competence of states in international law to adopt such legislation. Thus, the United States has provided by statute as follows :

.. it shall be unlawful, without the approval of the Secretary of Commerce, to sell, mortgage, lease, charter, deliver, or in any manner transfer, or agree to sell, mortgage, lease, charter, deliver or in any manner transfer, to any person not a citizen of the United States, or transfer or place under foreign registry or flag, any vessel or any interest therein owned in whole or in part by a citizen of the United States and documented under the laws of the United States. . . .87

The mutual respect which states exhibit for each other's legislative provisions of this nature is well expressed in the following communication of Secretary of State Lansing to the Department of Commerce:

... if the sale and the transfer to American citizens of a ship owned by the citizens and flying the flag of a foreign government, whose laws forbid such a transfer without the consent of its appropriate authorities, should be held by the competent tribunals of this country to be valid, it is plain that such transfer in contravention of the laws of the country of the ship's previous register would give rise to vexatious complications. . . The desirability, therefore, of the observance of the spirit of comity in the matter of the transfer of ships" registry is obvious. ${ }^{88}$

86 Art. 1, 3 Hudson, International Legislation 1848 (1931). A more recent example of the importance accorded to records kept in the state of national character is provided by the Convention on International Recognition of Rights in Aircraft, the purpose of which is, among other things, the protection of secured creditors and "facilitation of the transfer of aircraft from one nationality to another." For an analysis see Wilberforce, "The International Recognition of Rights in Aircraft," 2 Int. Law Q. 421, 424 (1948). 8746 U.S.C. 808 (1952).

882 Hackworth, Digest of International Law 763-764 (1941). 
Unless the competence for determination of ownership is in the state of registry, the registry will become a record of fraud and falsification rather than a reliable guide to the determination of rights in the ship. ${ }^{89}$ On the other hand, the fact that customary maritime law permits the creation of various unrecorded ("secret") liens which a vessel may "pick up" anywhere in the world for a variety of reasons, ${ }^{90}$ should not, of course, be interpreted as denial of either the flag state's competence to legislate with respect to determination of ownership or the national character of the vessel in question. The concession appears to be one of the hard necessities of international commerce.

\section{E. Claims to Requisition National Ships outside Territorial Domain}

One of the great incentives to states in attributing their national character to vessels is the expectation that these ships may be bases of national power in unforeseeable future exigencies. It does not appear unreasonable, absent overriding considerations of public policy, that states should indulge each other in this expectation. It would entirely defeat this expectation if the high degree of conclusiveness were not accorded to a state's attribution of its national character to a vessel.

States have unquestioned competence under appropriate conditions to requisition ships of their national character and even the ships of other states when these ships are under their effective control within their territorial domain. In addition, states are accorded competence to requisition ships having their national character which are not at the time of the requisitioning decree within their territorial domain. ${ }^{91}$ The fundamental principle is concisely stated, after a full review of relevant cases, by the late Professor Preuss:

For purposes of requisitioning, a national vessel is considered as "quasi-territorial." Therefore, the requisitioning of a ship while it is on the high seas (or, semble, while it is within the territorial waters of another state) is not an extraterritorial exercise of state authority. ${ }^{92}$

The application of this principle may be illustrated by numerous judicial decisions. Thus in 1916 Swinfen Eady, L.J., declared that it "is not disputed-indeed it is beyond dispute-that it is part of the prerogative of the Crown in times of emergency to requisition British ships." "93 Simi-

80 For comparable policy with respect to land recording, see McDougal and BrabnerSmith, "Land Title Transfer: A Regression," 48 Yale Law J. 1125 (1939) ; MeDougal, "Title Registration and Land Law Reform: A Reply," 8 U. Chicago Law Rer. 63 (1940).

so For a comprehensive and eritical survey, see Gilmore and Black, The Law of Admiralty, Ch. IX (1957).

21 "There are apparently no limits to this power, and the State in applying it is answerable to no other." Rienow, op. cit. note 61 above, at 7 .

92 "State Immunity and the Requisition of Ships during the Spanish Civil War," Part II, 36 A.J.I.L. 37, 55 (1942); for a review of British cases involving Spanish

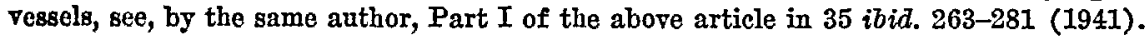

9s The Broadmayne, [1916] P. 64, at 67, cited with approval by Finlay, I. J., in The Arantzazu Mendi, [1939] P. 37, at 53. 
larly, during the second World War, in Lorentzen v. Lydden ${ }^{24}$ a British court upheld the competence of the Norwegian Government to decree the requisitioning of "All ships registered in Norway or belonging to a port there and situate outside the area" under the enemy occupation. The court declared that the decree was "in accordance with the comity of nations." 95 The decision in the famous and complicated case of the Spanish vessel Navemar ${ }^{26}$ was also in accord with these policies. Thus Judge Augustus $N$. Hand in the final stage of the litigation said:

It is not necessary to say that the decree effected an expropriation of the vessel while she was in foreign territorial waters at Buenos Aires, though it was promulgated and notification thereof was given to the master when the ship was at that port. Even if the decree might not be effective while the Navemar was at Buenos Aires, nevertheless it was an instrumentality of expropriation that would become operative upon the vessel as soon as she reached the high seas. ${ }^{97}$

Lord McNair's analysis of the relevant judicial decisions led him to reach the following conclusion, inter alia:

... the Crown has the right to requisition British merchant ships whether they are in British waters, on the high seas, or in foreign waters, and to enforce that requisition upon them anywhere except in foreign waters.

Conversely, the British Government and Courts should recognize a corresponding right in other States. ${ }^{98}$

\section{CLAIMS TO ACCESS AND FREEDOM OF NAVIGATION}

\section{A. Claims to Access}

\section{Claims to Access to the High Seas}

The claim to equal and unrestricted access to, and enjoyment of, the oceans is of course the most important of all the claims of states, and the most fundamental community policy is that of protecting this claim. The major jurisdictional principles for securing this policy-that each state may apply authority to vessels having its national character and that, except as authorized by international law, no other state may apply authority to such a vessel-are, as has been emphasized, built about a necessary identification of the national character of ships. It would appear reasonable that the degree of conclusiveness conferred by implementing procedural principles upon a state's attribution of national character to a vessel should be in direct proportion to the importance of the right. Certainly the right to equal aceess and enjoyment, through em-

94 [1942] 2 K. B. 202. 95 Ibid. at 216.

96 Compañia Española de Navegación Maritima v. The Navemar, 17 F. Supp. 495; ibid. 647 (1936); 18 F. Supp. 153; 90 F.2d 673 (1937); cert. granted, 302 U. S. 669 (1937); The Navemar, 303 U. S. 68 (1938), 32 A.J.I.I. 381 (1938); 24 F. Supp. 495 (1938); 102 F.2d 444; and supplemental opinion in $103 \mathrm{~F} .2 \mathrm{~d} 783$ (1939).

o7 102 F.2d 444, at 449.

$98 \mathrm{McNair}$, loc. cit. note 84 above, at 46 ; for an even more forcefully expressed view, see Rienow, op. cit. note 61 above, at 185 and 103-104. 
ployment of ships of national character, must be beyond unilateral challenge.

It is common knowledge that the historical claims to deny access to the high seas which rested on broad assertions of sovereignty over the oceans had largely been defeated by the 19 th century.99 While the more limited modern assertions of authority also raise issues involving freedom of the seas, it is now taken for granted that ships of all states may traverse the oceans free of prohibition by any state or group of states. ${ }^{100}$ Gidel has most aptly summarized both desirable general community policy and the pattern of state practice:

Ships of all nationalities have an equal right to make use of the high seas in every possible way, but the idea of equal use only comes second. The essential idea underlying the principle of freedom of the high seas is the concept of the prohibition of interference in peacetime by ships flying one national flag with ships flying the flags of other nationalities. The prohibition of interference is based on the idea of the flag, that is to say, the symbol of the attachment of the ship to a given State and not on the idea of the nationality of the individuals concerned in the maritime relations in question. ${ }^{101}$

The importance of this practice is emphasized in the presumption made explicit by the International Law Commission as the basis for its consideration of the regime of the high seas:

The principle generally accepted in international law that the high seas are open to all nations governs the whole regulation of the subject. ${ }^{102}$

If the great weight of this presumption needs emphasis it may be seen in the endorsement by the Permanent Court of International Justice of a general principle which remains authoritative to this day:

It is certainly true that-apart from certain special cases which are defined by international law-vessels on the high seas are subject to no authority except that of the State whose flag they fly. ${ }^{103}$

The pronouncements in which states and authoritative writers have endorsed the general principle of freedom of access, and the rôle of the national character of ships in protecting that freedom, could be multiplied almost endlessly. It is sufficient to note the most recent example in the 1958 Convention on the High Seas, Article 4: "Every State, whether coastal or not, has the right to sail ships under its flag on the high seas."

so Hall, International Law 178-190 (8th ed., Higgins, 1924); Lauterpacht, "Sovereignty orer Submarine Areas," 27 Brit. Yr. Bk. Int. Law 376, 403-405 (1950); Gidel dates the defeat of the notion of sovereignty over the high seas from the 17th century, in U. N. Secretariat, Regime of the High Seas, U. N. Doc. A/CN. 4/32, p. 3 (1950); Potter, The Freedom of the Seas 85-89 (1924); 1 Oppenheim, International Law 582587 (8th ed., Lauterpacht, 1955).

100 Lauterpacht, loc. cit. above, at 403-407; U. N. Secretariat, cited above, at 3 ; 1 Oppenheim, op. cit., at 587-592.

101 U.N. Secretariat, op. cit. note 99 , at $3-4$.

102 International Law Commission Report, Art. 27, Commentary, U.N. General Assembly, 11th Sess, Official Records, Supp. No. 9, p. 24 (A/3159) (1956) ; 51 A.J.I.L. 205 (1957).

10s The Lotus, P.C.I.J., Ser. A, No. 10, p. 25 (1927). 


\section{Claims to Access to Territorial Bases of Other States}

The relevant community policies here are the protection of vessels against the arbitrary assertions of effective power by coastal states and the securing to states of the full benefits promised by agreements providing access for their vessels. It is no longer questioned that each state may determine for itself whether or not to admit the vessels of other states to the areas of its exclusive competence. Access to such areas of exclusive competence is, of course, dependent upon explicit agreement. ${ }^{104}$ But numerous agreements, commonly called treaties of friendship, commerce and navigation, do stipulate for such access. It would completely defeat the purpose of these agreements if one party could unilaterally question attributions of national character by the other parties. Indeed, many of these agreements expressly make the parties' attributions of national character to ships conclusive, and this would seem to be the best and most economical general policy.

In countless treaties the national character of a vessel is made the determining condition of the exercise of the right of access. A typical provision in such treaties reads:

Vessels of either Party shall have liberty, on equal terms with vessels of the other Party . . . to come with their cargoes to all ports, places and waters of such other Party open to foreign commerce and navigation. ${ }^{105}$

The explicit provisions characteristic of these treaties, making the authoritative decision of a state in ascribing the national character to vessels conclusive, have already been illustrated with reference to British and American practice. For further example we may refer to a typical corresponding provision from a treaty concluded by France:

Les navires qui, selon les lois et règlements français, justifient de la nationalité française et les navires qui, selon les lois et règlements helléniques, justifient de la nationalité hellénique, seront, en ce qui regarde l'application de la présente Convention, considérés comme étant respectivement de la nationalité française et hellénique. ${ }^{108}$

It has been reported that between 1920 and 1940 forty-four states had concluded 151 agreements where an identical or similar standard was em-

104 Thus, e.g., Smith, The Law and Custom of the Sea 33 (3d ed., 1959); Sørensen, The Law of the Sea 200 (International Conciliation Pamphlet, No. 520, 1958). Contra, Colombos, The International Law of the Sea 129 (3d ed., 1954).

105 Treaty of Friendship, Commerce and Navigation between the United States of America and the Federal Republic of Germany, Oct. 29, 1954, Art. XX (1), 7 U. 8. Treaties and Other International Agreements 1839; T.I.A.S., No. 3593. Almost identical words can be found in corresponding treaties concluded by the United States with The Netherlands (March 27, 1956); Japan (Aug. 29, 1953); Greece (Aug. 3, 1951); and Italy (Feb. 2, 1948).

108 Convention of Commerce and Navigation with Greece, of March 11, 1929, Art. 26. Similar provisions may be found in treaties concluded by France with the BelgiumLuxembourg Economic Union (Feb. 23, 1928), Art. 17; Estonia (March 15, 1929), Art. 30; Yugoslavia (Jan. 30, 1929), Art. 25, and with other states. Niboyet-Goule, Recueil de Textes Usuels de Droit International, Supplément, 1929 (1930). 
ployed. ${ }^{107}$ Even when there is no agreement between the two states, access is not denied on the ground that the flag state was without competence to confer its national character upon a vessel under conditions of its own choice. The one instance in recorded American experience in which the question of flag arose concerned a vessel carrying documentation issued by Manchukuo, and the State Department took the view that since the United States did not recognize Manchukuo as a state, the documents had no validity for the United States. The United States did not, however, allege that the foreign state had no authority to confer national character on the vessel concerned, but that there was no foreign state involved at all and, therefore, the documentation could not be accepted as valid. ${ }^{108}$

The more important discussions of this problem fail to provide examples where the authoritative ascription of national character was denied for purposes of access.

\section{Claims to Access to International Waterways under Special Regime}

The policy recommended with respect to international waterways ${ }^{109}$ under special regime, indispensable to the economic use of the oceans, must necessarily be identical to the policy recommended with respect to access to the oceans. A state's attribution of its nationality to a vessel seeking passage through the waterway should be regarded as conclusive. A careful study of the more important sources fails to disclose any instance in which a ship has been denied the right of passage through such international waterways because a territorial Power controlling the waterway has found it lacking sufficient connection with the state of attribution. ${ }^{110}$

107 In a book based on an extensive analysis of treaty provisions "of a type that recur in the more basic and relatively long-term treaties of commerce, navigation, and establishment," Professor Hawkins states: " ... the usual treaty practice is to identify as national vessels those registered under the respective laws of the parties. From 1920 to 1940, forty-four states concluded 151 agreements in which this standard of national laws and registry was used, and only four countries defined vessels of the contracting parties in a vague or different manner." Hawkins, Commereial Treaties \& Agreements 6 (1951).

108 2 Hackworth, Digest of International Law 207-208 (1941).

100 The waterways to which we are referring are those administered under special agreements, such as the Suez Canal and the Panama Canal. It will be recalled that Art. 1 of the Convention of Constantinople, 1888, explicitly provides that the Suez Canal "ghall always be free and open, in time of war as in time of peace, to every vessel of commerce or of war, without distinction of flag." 3 A.J.I.I. Supp. 123 (1909); Hallberg, The Suez Canal 407 (1931). The obligation of the United States with respect to the Panama Canal is somewhat less explicit. See Padelford, The Panama Canal in Peace and War 92 (1942), and 3 A.J.I.I. Supp. 128, 137 (1909).

If inquiry is extended to straits, then the decision in the Corfu Channel Case becomes relevant. It will be remembered that the decision of the International Court of Justice suggests that a condition of unfriendly relations short of war would not be sufficient to authorize the coastal state to deny access to foreign warships. Judgment of April 9, 1949, [1949] I.C.J. Rep. 4; 43 A.J.I.I. 558 (1949).

110 Hallberg and Padelford, op. cit. above, give the most detailed discussions of the two most important canals. See also Schonfeld, The Suez Canal in World Affairs 128129 (1953). 
To cite the most prominent recent controversy, Egyptian practice in denying passage through the Suez Canal to Israeli ships does not appear to rest on the claim that Israel does not exist as a state or that Israel is otherwise incompetent to confer national character on vessels, but has instead assumed that the attribution by the state of Israel is conclusive. The Bat Galim, the only vessel Israel has attempted to send through the Canal, was seized by Egypt for the reason that it undoubtedly was an Israeli vessel. ${ }^{111}$

Apart from identifying vessels which the coastal state may seek to exclude from passage, national character has also been important for purposes of protecting alleged rights of access to international waterways. A number of states whose ships have been affected by Egyptian authority over the Suez Canal in connection with Israel have offered protests against the permissibility of the action taken. ${ }^{112}$

\section{B. Claims with Respect to Securing Shared Enjoyment of Fishing on the High Seas}

\section{Claims Relating to Fishing in Areas of Shared Use and Competence}

For the most productive and harmonious exploitations of the riches of the oceans, equality of access for fishing is no less important than equality of access for navigation, and should therefore be protected by the same jurisdictional and procedural policies. Fortunately, practice is thoroughly in conformity with this policy. Assertions by a state of competence to secure free access to a fishery for vessels with its national character appear never to have been denied on the ground that the vessel did not possess that character or that the state was not competent to confer its nationality on the vessel in question. 113 The classic case remains that of the Norwegian trawlers in the Moray Firth. It will be recalled that after the Firth had been closed to trawling, British owners began to use trawlers registered in Norway. The foreign masters of some of these Norwegian-registered ships were arrested, found guilty and fined for violation of the prohibition, but upon protest by Norway against three of these convictions, the men were released. According to Fulton,

It was subsequently explained that in taking this action Norway was merely maliing a formal stand for the rights of her flag, since the trawlers had been registered in Norway in a legal way, Norwegian subjects were concerned, and no claim had been put forward on behalf of the British Government to the Moray Firth as being territorial in character. ${ }^{114}$

111 Gross, "Passage through the Suez Canal of Israel-Bound Cargo and Israel Ships," 51 A.J.I.L. 530 (1957). 112 Ibid.

113 Account of disputes involving the major fisheries of the world may be found in Fulton, The Sovereignty of the Sea (1911); Innis, The Cod Fisheries (rev. ed., 1954); Leonard, International Regulation of Fisheries (1944); Oda, " $\mathrm{New}$ Trends in the Regime of the Seas," 18 Zeitschrift für Ausländisches Offentliches Recht und Völkerrecht 61, 68-86 (1957); Tomasevich, International Agreements on Conservation of Marine Resources (1943); Gregory and Barnes, North Pacific Fisheries 281-302 (1939). 114 Fulton, op. cit. above, at 728; see also Leonard, op. cit. above, at 48-55; Briggs, The Law of Nations 52-57 (2đ ed., 1952). 
In more recent years the most famous case of interference with fishing on the high seas involved the seizure of Panamanian ships by Peru for alleged violations of the Peruvian territorial sea and of its regulations for fishing beyond that area, and protest was promptly offered by Panama, the United States and the United Kingdom. ${ }^{115}$ So far as is known, Peru did not reject the Panamanian protest on the ground that the vessels did not partake of the national character of Panama, although it was a wellknown fact, repeated in numerous contemporary accounts of the affair, that the vessels in question had varying connections with several states.116

These illustrations could, of course, be supplemented by almost innumerable other accounts, historical and contemporary. The 1958 Conference on the Law of the Sea furnishes the best evidence of the consensus on the importance and conclusiveness of the nationality of vessels in this context. The Convention on Fishing and Conservation of the Living Resources of the High Seas deals with fishing problems solely in areas of inclusive use, as Article 1 affirms, by declaring that "All States have the right for their nationals to engage in fishing on the high seas. ..."117 For implementation of this right, as well as of other prescriptions affecting it, the convention provides that the reference to "nationals" means "fishing boats or craft of any size having the nationality of the State concerned, according to the law of that State, irrespective of the nationality of the members of their crews." 118 It would be difficult to imagine more explicit emphasis upon the conclusiveness of unilateral attributions of nationality than this unequivocal declaration in the most important multilateral convention of modern times on the subject.

\section{Claims Relating to Fishing in Areas of Exclusive Competence}

The importance of the conclusiveness of the national character of vessels here is again effectively to secure such vessels against unlawful assertions of exclusive competence. Reference may again be made to the 1958 Conservation Convention, which provides for certain measures of exclusive competence in coastal states for regulating adjacent fisheries. ${ }^{119}$ In ac-

115 Phleger, "Some Recent Developments Affecting the Regime of the High Seas," 32 Dept. of State Bulletin 934 (1952); U.S. Naval War College, International Law Situation and Documents 1956, 289-294 (1957).

116 Although The Economist mistakenly, but perhaps understandably, concluded that the "resulting situation is an international lawyer's nightmare," the multiple connections in the case were pithily described: "An Argentine citizen, of Greek origin, resident in France, and whose ships fly a Panamanian flag and carry German crews and British insurance, has been attacked at sea by Peru, which is supported by Ecuador and Chile." The Economist, Nov. 27, 1954, p. 715.

1172 Official Records 139 ; 52 A.J.I.t. 852 (1958). Art. 1, par. 1, provides in full: "All States have the right for their nationals to engage in fishing on the high seas, subject (a) to their treaty obligations, (b) to the interests and rights of coastal States as provided for in this Convention, and (c) to the provisions contained in the following articles concerning conservation of the living resources of the high seas."

118 Art. 14. 2 Official Records 141; 52 A.J.I.I. 856 (1958).

119 Art. 7 of the convention permits unilateral adoption of conservation measures by a coastal state if negotiations with other states concerned have not produced agreement 
cording rights to, and imposing obligations upon, non-coastal states, the convention speaks repeatedly of "States whose nationals" engage in fishing, and identification of the state thus referred to is achieved by reference to fishing boats which have "the nationality of the State concerned, according to the law of that State. ..."120

\section{Claims with Respect to Securing Shared Use for Submarine Cables and Pipelines}

The importance of national character extends beyond the protection of vessels for abuses of authority to identification of the states responsible for the conduct of vessels and competent to apply authority to vessels for harmful conduct. Both by customary law and by treaty, determination of the state responsible for imposing sanctions for harm to submarine eables has been by identification of the national character of the vessel charged with causing the harm. The 1884 Convention for the Protection of Submarine Cables, to which a large number of states have subscribed, authorizes warships of one state to stop vessels of another to investigate for complicity in interference or damage to cables, but imposes responsibility for enforcement upon the courts of the state to which the vessel belongs. ${ }^{121}$ The obligations imposed by this convention on the state of national character were recently emphasized in the note of March 23, 1959, from the United States to the Soviet Union declaring the former's belief that a trawler flying the Soviet flag had violated Article II of the Convention of 1884, and noting that

Article VIII et seq. of the convention place the responsibility for the repression of these violations of the convention and trial and punishment of the violators on the Soviet Union. Therefore, the Government of the United States calls upon the Government of the Union of Soviet Socialist Republies to discharge its international obligations as summarily as its laws and regulations will permit, by promptly . . . taking such measures as are necessary to punish those who may be found to be guilty. ${ }^{122}$

The Geneva Convention on the High Seas also imposes several obligations upon the state which has attributed its national character to an offending vessel. ${ }^{123}$

\section{Claims With Respect to Shared Use of Airspace above the High Seas}

The conclusiveness of the national character of aircraft for purposes of securing equality of access to the airspace above the high seas, and for

within six months. Provision is made for challenging the validity of these measures according to specified criteria, but the conservation program remains in force pending conclusion of the procedure provided for settling the dispute. 2 Official Records 140; 52 A.J.I.L. 853 (1958). 1202 Official Records 141.

121 U.N. Legislative Series, Laws and Regulations on the Regime of the High Seas 251 (U.N. Doc. ST/LEG/SER. B/1) (1951); Wilson, Submarine Telegraphic Cables in Their International Relations 12-13 (1901) (Lectures delivered at the U. S. Naral War College).

122 Text of the note is in 40 Dept. of State Bulletin 555 (1959).

123 Arts. 27 and 28. 2 Official Records 138; 52 A.J.I.L. 849 (1958). 
protecting aireraft against abuses of authority, would appear to be no less indispensable than the comparable conclusiveness with respect to vessels. ${ }^{124}$

It is an interesting parallel, not only with respect to the shared use of airspace above the high seas but with respect to the use of aircraft generally anywhere, that the important jurisdictional discriminations are made in terms of the national character of the craft and that states' authoritative decisions about the national character are regarded as conclusive. Indeed, both multilateral and bilateral air agreements accord privileges to, and impose burdens upon, aircraft having the national character of the contracting parties, and, as the Chicago Convention of 1944 puts the matter bluntly in Article 17, "aircraft have the nationality of the State in which they are registered." 125 No provision is made for questioning a state's authoritative decision about registration upon any ground.

\section{CLAIMS WITH RESPECT TO EVENTS DIRECTLY AFFECTING COMMON ENJOYMLENT OF THE HIGH SEAS}

\section{A. Claims to Protect Minimal Order}

\section{Claims against Other States for the Lawful Conduct of Ships and} Aircraft to Which They Have Ascribed. Their National Character

The importance of the national character of ships and aircraft for the maintenance of minimal order lies in the certain and easy identification of the parties responsible for particular breaches of public order of the high seas. Ships may, of course, be instruments of coercion and violation of fundamental community preseriptions, and states may find it necessary to apply the laws of war and neutrality to vessels in the course of conflict. ${ }^{126}$

124 Art. 2 (4) of the Convention on the High Seas states, in summary of accepted customary law, that freedom of the high seas embraces inter alia "freedom to fly over the high seas." On the other hand, ICAO's "Rules of the Air" - pursuant to Article 12 of the Chicago Convention, the only standards of flight and maneuver in force over the high seas-prescribe: "The Rules of the Air shall apply to aircraft bearing the nationality and registration marks of a Contracting State." Rules of the Air, Annex 2, ad ed., April, 1952, 2.1.

1:5 Convention on International Civil Aviation, signed at Chicago, Dec. 7, 1944. I.C.A.O. Doc. 7300; ঢ. S. Dept. of State Pub. 2282 (Conf. Ser. 64). The U. S. Federal Aviation Aet of 1958, 72 Stat. 731 (Publie Law 85-726, 85th Cong., S.3880), provides in Sec. 501 (a) for compulsory registration of aireraft. Par. (f) of the same section reads: "Such certificate of registration shall be conclusive evidence of nationality for international purposes. ..."

126 There is, of course, a great body of prescriptions uniquely applicable when outbreaks of comprehensive violence oceur, and the slogan "freedom of the seas" for many decades was most frequently used in such a context. See Potter, The Freedom of the Seas 81-96 (1924). See also Tueker, The Law of War and Neutrality at Sea (1957); Stone, Legal Controls of International Conflict (1954); 2 Oppenheim, International Law (7th ed., Lauterpacht, 1952).

It may be remembered, howerer, that the policies and factors relevant for determining the "enemy character" of ships and goods in time of war are very different from those relevant for determining the nationality of ships. The two types of problems have very little in common. Rienow, op. cit. note 61 above, at 130, and sources there cited; McNair, "The National Character and Status of Corporations," 4 Brit. Yr. Bk. Int. Iaw 44-56 (1923-1924); see also The Unitas, [1950] A.C. 536. 
In these latter circumstances the national character of vessels is again important for protection against abuses of authority. This certain and easy identification of vessels is so important that special punitive measures are allowed against stateless ships and ships which fraudulently change their flag.

As a general principle, derived as we have seen from the overriding community policy assuring free access to the vessels of all states, ships of one state are prohibited from interfering with vessels of another state on the high seas. ${ }^{127}$ In application of the fundamental policies of the United Nations Charter about impermissible coercion, ${ }^{128}$ as in the more limited traditional preseriptions limiting resort to coercion, states are held accountable for ships of their national character and it is commonly assumed as basic that attributions must be regarded as final. ${ }^{120}$

Where states authorize ships having their national character to interfere with ships of other states, the flag state is responsible for any deprivations imposed. Flag states are universally held to be strictly accountable for the actions of state ships even in stopping foreign vessels upon the high seas, if for an impermissible purpose, ${ }^{\mathbf{1 3 0}}$ as well as for prohibited activities within the areas of the exclusive authority of other states. ${ }^{131}$ Recently, for example, the Soviet Union protested as "completely unjustified" the action of an American destroyer, which had stopped and boarded a Soviet fishing vessel in the Atlantic for investigation of the possibility that it had caused numerous cable breaks in the area. ${ }^{132}$ The boarding action was undertaken in this instance in pursuance of a treaty to which both the United States and the Soviet Union had adhered, and which imposed liability upon the flag state of the boarding ressel if the actions were unwarranted; but by customary law, too, responsibility would have been imposed on the United States if there had been no treaty anthorizing this action. The importance of national character here is, thus, as elsewhere, ${ }^{133}$

127 See note 100 above.

128 For exposition and analysis, see MeDongal and Feliciano, "Iegal Regulation of Resort to International Coercion: Aggression and Self-Defense in Policy Perspective," 68 Yale Law J. 1057 (1959).

128 The problem here is not that some other state's national character ought to be impressed upon a vessel, but that the flag state cannot be permitted to shift responsibility for the acts of its vessels. Tucker, The Law of War and Neutrality at Sea 38-41 (1957).

130 In The Jessie, The Thomas F. Bayard and the Pescawha, a case involving claims by Britain on behalf of British sealing vessels, the actions of the American vessel in stopping and searching the vessels on the high seas were not done with the authorization of the U. S. Government, but the United States was held responsible. 6 Rep. Int. Arb. Awards 57 (1955); also reported in Briggs, Law of Nations 327-328 (2d ed., 1952); and see authorities cited ibid. at 328-330.

131 Corfu Channel Case, Judgment of April 9, 1949, [1949] I.C.J. Rep. 4; 43 A.J.I.L. $558(1949)$. 13240 Dept. of State Bulletin 558 (1959).

133 Thus, in another context requiring identification, Colombos states: "The na. tionality of a ship is one of the guarantees offered by international law for the freedom of navigation, and every ship which sails the high seas must possess a national character and be in a position to provide evidence of it. The possession of a nationality is the 
in its indispensability to the quick and easy identification of responsible parties.

When deprivations of a substantial character imposed by private vessels are unauthorized, the acts may be regarded as piratical and, as we will see, the ship and its crew may be made responsible, irrespective of their national character.

\section{Claims to Repress Piracy}

In a domain subject to no exclusive competence of any particular state and with no centralized international administration of sanctions, it is of course necessary to make special provision for the repression of private violence. Historically this has been achieved through development of rules relating to piracy. The community considers the maintenance of public order on the high seas of such vital importance that all states are authorized to take measures against private violence, appropriately characterized as "piracy," irrespective of the national character of the offending ship. ${ }^{134}$

Whatever difficulties there may have been in the past in achieving an agreed definition of the substantive elements of piracy, ${ }^{135}$ the basic jurisdictional principle in repression of piracy has long been both certain and agreed. Thus the matter was put sharply by Lord Stowell in the case of Le Louis, where he declared that pirates are "the enemies of every country, and at all times; and therefore are universally subject to the extreme rights of war." 136 To similar effect Mr. Justice Story, in United States v. Smith, described piracy as follows:

basis for the intervention and protection by a State; it is also a protection for other States for the redress of wrongs committed by those on board against their nationals." International Law of the Sea 216 (3rd ed., 1954). Compare also 1 Gidel, Le Droit International Public de la Mer 74 (1932).

Professor Van Bogaert of the University of Ghent, noting that international law requires that erery ship which narigates the high seas hare a national character, states: "Cette obligation est basée sur la considération qu'un navire doit être soumis à un régime juridique déterminé, qui règle les relations à bord du navire, qui assure la protection éventuelle de la part de l'Etat du pavillon et qui rend cet Etat responsable envers les autres Etats pour les infractions commises contre les règles du droit international public maritime." "Le droit que possède l'Etat pour déterminer les conditions d'apres lesquelles les narires ont le droit d'arborer son pavillon," 35 Revue de Droit International et de Droit Comparé 485 (1958).

134 See Harvard Research in International Law, Piraey, 26 A.J.I.L. Supp. 739, at 757 (1932).

135 " It is of considerable importance that there be no confusion about the significance of the proposition that pirates jure gentium are hostes humani generis. Is the jurisdiction universal because they are hostes humani generis, or are they said to be hostes lumani generis because the jurisdiction is universal? Does the proposition state a prerequisite or a consequence? Does it describe a constituent element of the offense of piracy or only a reprehensible quality or characteristic which the law attributes to pirates? It is evident that the applicability of the law of piracy to modern marauders on the sea, including the 'hi-jackers,' for example, may depend much upon the correct answers to these questions." Diekinson, "Is the Crime of Piracy Obsolete", 38 Harvard Law Rev. 334, 351 (1924-1925). $\quad 136$ Le Loutis, [1817] 2 Dodson 210, 244. 
The common law, too, recognises and punishes piracy as an offence, not against its own municipal code, but as an offence against the law of nations (which is part of the common law), as an offence against the universal law of society, a pirate being deemed an enemy of the human race. ${ }^{137}$

A century later, the Sub-Committee of the League of Nations Committee of Experts for the Progressive Codification of International Law, reporting on piracy in 1926, formulated the problem in these words:

Piracy has as its field of operation that vast domain which is termed "the high seas." It constitutes a crime against the security of commerce. ...

When pirates choose as the scene of their acts of sea-robbery a place common to all men and when they attack all nations indiscriminately, their practices become harmful to the international community of all States. They become the enemies of the human race and place themselves outside the law of peaceful people. ${ }^{138}$

The most recent formulation is Article 19 of the Geneva Convention on the High Seas, which reads:

On the high seas, or in any other place outside the jurisdiction of any State, every State may seize a pirate ship or aircraft, or a ship taken by piracy and under the control of pirates, and arrest the persons and seize the property on board.

The point we emphasize here, as elsewhere, is that uniform and universal application of the same policies to the ships of all states, irrespective of national character, is no denial of the conclusiveness of attributions of national character. The convention itself in Article 18 makes this explicit, noting that a "ship or aircraft may retain its nationality although it has become a pirate ship or aircraft," 139 and adding that the "retention or loss of nationality is determined by the law of the State from which such nationality was originally derived."

\section{Claims with Respect to Stateless Ships}

So great a premium is placed upon the certain identification of vessels for purposes of maintaining minimal order upon the high seas, as indicated above, that extraordinary deprivational measures are permitted with

13718 U. S. (5 Wheat.) 153, 161 (1820). Similarly Mr. Justice Johnston in United States $v$. Bowers, ibid. 190 (1820), especially at 193, 194-195.

13s Report of the Sub-Committee of the Committee of Experts for the Progressive Codification of International Law 117 (League of Nations Pub. No. C. 196. M. 70. 1927. V; 20 A.J.I.I. Spec. Supp. 224 (1926)). See also Harvard Research in International Law, Jurisdiction with Respect to Crime, Art. 9, 29 A.J.I.L. Supp. 435 (1935); Johnson, "Piracy in Modern International Law," 43 Grotius Society Transactions 63 (1959).

139 But Professor A. Pearce Higgins, stressing the "jurisdictional competence" of the state of national character over its ships on the high seas, seems to imply that oven piracy does not constitute a derogation of this "general rule" because it is, in fact, "denationalization" of the pirate ship which has become a hostis humani goneris. Higgins, "Le Régime juridique des navires de commerce," 30 Hague Acadomy Rocuoil des Cours 5, at 18 (1929, V). 
respect to stateless ships. Thus, it is commonly considered that ships either having no nationality or falsely assuming a nationality are almost completely without protection. It is obviously an extreme view to regard such ships as hostes humani generis, but there appear no clear policies which might protect such ships from very summary treatment.

Excellent illustration of this severity in community attitude is found in a relatively recent decision of the British Privy Council in NaimMolvan v. Attorney General for Palestine. ${ }^{1+0}$ In this case the vessel Asya, sailing in 1946 from a French port towards Palestine with several hundreds of illegal immigrants aboard, was apprehended some 100 miles off the coast by a British destroyer. When first sighted, the Asya was flying no flag; however, it hoisted the Turkish flag, which was soon hauled down and replaced by a Zionist flag. Having no documents with which to prove its national character, the ship was subsequently taken by the destroyer to Haifa, and eventually by a court ordered forfeited to the Government of Palestine. Affirming the judgment of the Supreme Court of Palestine, the Privy Council through Lord Simonds declared that the freedom of the high seas is "a freedom of ships which fly, and are entitled to fly, the flag of a State which is within the comity of nations." 141 "The Asya did not satisfy these elementary conditions," in the opinion of the Court, and, therefore, "could not claim the protection of any State nor could any State claim that any principle of international law was broken by her sioizure." 14:

One very effective restraint upon the frequency of stateless ships in fact is that access to the ports of states is, as we have seen, largely secured through agreements which bestow the right of access only upon the ships having the national character of the parties. Rienow has rightly observed that "It is by this control of their ports that States, in practice, clear the high seas of nondescript vessels." 143

\section{Claims to Take Punitive Measures against Ships Fraudulently Changing Flags on the High Seas}

'l'he same policy prevails in the drastic penalties provided for vessels fraudulently changing flags on the high seas. This policy, thoroughly clarified in a long process of customary development, is clearly expressed in the Geneva Convention on the High Seas, Article 6 of which provides:

1. Ships shall sail under the flag of one State only and, save in exceptional cases expressly provided for in international treaties or in these articles, shall be subject to its exclusive jurisdiction on the high seas. A ship may not change its flag during a voyage or while in a port of call, save in the case of a real transfer of ownership or change in registry.

2. A ship which sails under the flags of two or more States, using them according to convenience, may not claim any of the nationalities

140 [1948] A.C. 351; 42 A.J.I.I. 953 (1948).

141 [1948] A.C. 351, at $369 . \quad 142 \mathrm{Ibid}$. at 369-370.

143 Rienow, The Test of the Nationality of a Merchant Vessel 15 (1937). 
in question with respect to any other State, and may be assimilated to a ship without nationality. ${ }^{144}$

It must, however, be noted that the exception stated in Article 6(1) in the following words- "save in the case of a real transfer of ownership," is most unfortunate. This exception would appear to authorize a change of flag upon the high seas without change in registry, thus destroying the security of the registry and encouraging artistry in quick and fraudulent change of flags. ${ }^{145}$

\section{Claims to Prevent Use of Ships in Slave Trade}

The common interest in repressing the slave trade, similarly, is so great that especially severe measures have been allowed against ressels employed for that purpose. It is, nevertheless, somewhat paradoxical, since slavetrading involves attacks upon human dignity rather than upon goods, that customary international law did not establish the same universal jurisdiction with respect to slave-trading as with respect to piracy. This defect has, however, been remedied by various international agreements subseribed to by varying numbers of states, and authorizing states to apply varying degrees of authority to each other's ships for the repression of slave-trading. ${ }^{146}$ Considerably more modest in scope are some of the more recent conventions, such as the Geneva Slavery Convention of 1926, ${ }^{147}$ the Supplementary Convention on the Abolition of Slavery, the Slave Trade, and Institutions and Practices Similar to Slavery, 1956,148 and the Convention on the High Seas of 1958, in which it has been left to every state to adopt effective measures "to prevent and punish the transport of slaves" in ships having its national character. ${ }^{149}$ Although regrettably limited, these prescriptions do emphasize the importance which states place upon respect for the conclusiveness and significance of national character.

14452 A.J.I.I. 844 (1958). See also note 140 above, and accompanying text.

145 Our criticism here is parcel of our more comprehensive criticism of the convention 's emphasis upon documentation and flag rather than registration as indications of the attribution of national character. See below, pp. 101-103.

It may be added that in this context the word "or" in "save in the case of a real transfer of ownership or change in registry" probably is not to be interpreted as mealling "that is to say." For the ambiguities of this term, see Allen, "Toward a Procedure for Detecting and Controlling Syntactic Ambiguity in Legal Discourse," An International Conference for Standards on a Common Language for Machine Searching and Translation, Cleveland, Ohio, Western Reserve University, Sept. 6-12, 1959; "And/or," 18 A.B.A.J. 456 (1932); Note, "In Defense of 'And/or," 45 Yale Law J. 918 (1936).

146 For a brief summary of the United States attitude towards the establishment of an international penal jurisdiction with respect to suppression of slave-trading, seo McDougal and Arens, "The Genocide Convention and the Constitution," 3 Vanderbilt Law Rev. 683, at 698-700 (1950); and Wilson, "Some Principal Aspects of British Efforts to Crush the African Slave Trade, 1807-1929," 44 A.J.I.L. 505 (1950).

147 3 Hudson, International Legislation 2010 (1931).

148 Relevant articles are in U.N. Legislative Series, Supplement to Laws and Regulations on the Regime of the High Seas and Laws Concerning the Nationality of Ships 70 (U.N. Doc. ST/LEG/SEB. B/8) (1959).

149 Art. 13. See also Colombos, op. cit. note 133 above, at 341-345. 


\section{B. Claims with Respect to Securing Safe and Ordered Navigation ${ }^{150}$}

It is a common practice in conventions designed to secure safe and ordered navigation to impose upon each state responsibility for securing conformity by vessels of its national eharacter with the standards preseribed by such conventions. ${ }^{151}$ No other state is commonly authorized to apply its authority to vessels for securing such conformity. Under the existing circumstances, in the absence of a centralized enforcement agency, and with the exigencies of ocean commerce requiring swift identification, it is only natural that the state which has attributed its national character to a vessel should be rested with exclusive authority to enforce compliance with international rules relevant to safety of navigation. This policy seems to be applicable to all the types of conventions dealing with matters of safety at sea.

The new Geneva Convention on the High Seas embraces provisions substantially comparable to those found in many previous separate conventions, such as those of the types itemized above in the process of claim. This most recent convention similarly employs the same jurisdictional and procedural principles as are employed in the separate conventions. Thus, for example, the Geneva Convention provides that every state shall take measures with respect to "ships under its flag" to conform with international standards designed to ensure and promote safe and ordered sea navigation. ${ }^{152}$ It will be noted that no provision is made for going behind the authorized flag.

150 Even before the advent of explicit agreements, there were widely accepted uniform rules for regulating navigation upon the high seas. See The Scotia, 81 U. S. (14 Wall.) 170 (1871).

151 The most important multilateral agreements with respect to safety of navigation are the International Convention for the Safety of Life at Sea, 1948, in force since Nov. 19, 1952, the International Load Line Convention, 1930, and some of the I.L.O. conventions relating to the adequacy and competence of the erew and labor conditions on ships. As of Jan. 1, 1954, ocean navigation is regulated by the new International Regulations for Preventing Collisions at Sea, agreed upon at the 1948 International Conference on Safety of Life at Sea and attached to the Final Act of the conference as Annex B, commoniy called the International Rules of the Road. These Rules have been alopted by more than fifty states, among them all the principal maritime Powers, including the U.S.S.R. "Most maritime countries follow the basic International Rules in their local waters as well as on the high seas, adding special rules to supplement the International Rules when local conditions so demand." Farwell and Prunski, The Rules of the Nantical Road 11 (rev. ed., 1959). See also Reiff, The United States and the Treaty Law of the Sea 227 et seq. (1958). For a general survey of the maritime sessions of the International Labor Organization during the past four decades, see "Seven Maritime Sessions of the International Labour Conferenee," 78 Int. Labour Rev. 429460 (1958). For texts of I.L.O. maritime conventions, see 1 International Labour Code 1951, Bk. IX (1952).

In addition to the above, the following agreements bear more importantly upon the safety of ocean narigation: International Code of Signals, Agreement concerning Maritime Signals, 1930; Convention for the Unification of Certain Rules of Law with respect to Assistance and Salvage at Sea, 1910 (Art. 11 in particular); and Convention for the Unification of Certain Rules of Law with respect to Collisions between Vessels, 1910 (Art. 8 in particular). 152 Arts. 10 and 12 . 


\section{Claims Relating to Control of Pollution}

The importance of national character of ships in administering community policies for control of pollution is again in the easy identification of a responsible party which it offers. The state of national character may be required by agreement to preseribe the necessary regulations for its ships, and it has authority to apply coercion to its ships in sanction of these regulations. The state of national eharacter may further be made responsible for appropriate observance by its vessels and, in additional precaution, other states may under certain conditions be given coneurrent jurisdiction.

These policies find illustration in the London Convention for the Prevention of Pollution of the Sea by Oil, 1954, in force since July 26, 1958. ${ }^{158}$ The convention refers in a number of articles to "sea-going ships registered in any of the territories of a Contracting Government," and the contracting government assumes responsibility for securing the compliance by vessels of its national character with the provisions of the agreement. ${ }^{154}$ The convention further authorizes every contracting state to report contraventions by vessels of any other contracting state, wherever they may oceur, to the government of the country whose national character the offending vessel possesses. ${ }^{155}$ The unimpaired competence of each state to prescribe and apply measures for preventing pollution of waters within its territorial domain to all ships, irrespective of their national character, involves of course no detraction from the conclusiveness of attributions of national character. ${ }^{156}$ The provisions of Articles 24 and 25 of the Geneva Convention on the High Seas are comparable to those of the London Convention of 1954.

\section{Claims to Temporary Exclusive Use in Non-Contiguous Areas of the} High Seas and Airspace Above

The basic assertion of authority here is for purposes of naval maneuvers, nuclear experiments of great importance to the national security of the elaimant state, and for experimentation usually related to military uses of outer space (testing range for missiles). Naval maneuvers constitute a common example of this type of claim of unquestioned legality. Quite

153 U.N. Legislative Series, op. cit. note 148 above, at 33. The Geneva Convention on the High Seas contains some very general preseriptions on problems of pollution by nuclear materials. See the JAG Journal, April, 1959, for a useful survey of the legal problems involved in the use of nuclear-powered ships, including submarines.

154 Thus, for example with slight modifications, Arts. II, III, V, VII and X.

155 Art. $X(1)$. Art. $X$ (2) further provides: "Upon receiving such particulars the latter Government [i.e., of ship's nationality] shall investigate the matter, and may request the former Government to furnish further or better particulars of the alleged contravention. If the Government in the territory of which the ship is registered is satisfied that sufficient evidence is available in the form required by law to enable proceedings against the owner or master of the ship to be taken in respect of the alleged contravention, it shall cause such proceedings to be taken as soon as possible. ..."

156 See, e.g., British Oil in Navigable Waters Act, 1955, Art. 14 (1). U.N. Iregislative Series, op. cit. note 148 above, 37 at $39-40$. 
controversial recent examples of the assertions of claims of this type are those of the United States and the United Kingdom to conduct nuclear experiments on the high seas vital to their security. The significance of national character here is the same as in all interactions in which the necessity arises for the protection of vessels against alleged abuses of authority. The policies which we have recommended for protection generally are equally applicable to these problems.

This type of exclusionary claim is usually made known by giving notice, through channels of information familiar and accessible to mariners all over the world, that certain defined areas will be unsafe for navigation for certain specified periods of time. The areas so designated are customarily so circumscribed and selected as to create the least possible interference with other uses of the ocean. Literally hundreds of these areas have been established by the United States, and other states, including Great Britain, the Soviet Union and France, have engaged in the same practice. In previous summary, it is observed: "Although such claims may be traced indirectly to antiquity, their legality has seldom been questioned or even discussed." 15i

In addition to affecting the competence to protest the legality of claims to exclusive use, the nationality of ships is here important for identifying the state which may attempt to recover damages for harm caused by the activities which necessitate creation of the exclusive area. Thus, in the case of the hydrogen bomb tests in 1954, Japan presented a claim for two million dollars on behalf both of the crew of a Japanese fishing vessel injured by effects of the test and of the Japanese fishing industry. Japan explicitly refused to request discontinuance of the tests and the United States satisfied the monetary claim "without reference" to questions of legal liability. 158

\section{CLAIMS RELATING TO EVENTS OCCURRING ON BOARD SHIP ON THE HIGH SEAS}

It is important that a clear distinction be made between events which affect the public order of the vessel and those which do not. ${ }^{159}$ The in-

15: McDougal and Schlei, "The Hydrogen Bomb Tests in Perspective: Lawful Measures for Security," 64 Yale Law J. 648 (1955), establishes the case for the lawfulness of the hydrogen bomb tests in terms of the law of the sea. For other views see Margolis, "The Hydrogen Bomb Experiments and International Law," ibid. 629; Gidel, "Explosions Nucléaires Expérimentales et Liberté de la Haute Mer," in Grundprobleme des Internationalen Rechts: Festschrift für Jean Spiropoulos 173 (1957), commented upon in McDougal and Burke, "Crisis in the Law of the Sea: Community Perspectives versus National Egoism," 67 Yale Law J. 539, 547, note 28 (1958).

$158 \mathrm{McD}$ ougal and Schlei, loc. cit. above, at 694-695.

$150 \mathrm{By}$ distinguishing between events which affect the public order of the ship and those which do not, we intend only to emphasize the special interest of the flag state in certain events. The events on board a ship on the high seas are components of larger community processes, and states other than the flag state may be concerned with their impact, as, for example, upon their nationals. Thus, such states may in appropriate cases reasonably assert a coneurrent competence even with respect to events primarily affecting the public order of the ship. Our distinction merely seeks to secure that the unique character and impacts of events on board ship be given appropriate policy consideration.

The famous case which is associated with recognition of this concurrent competence is, 
terest of the state of national character is most substantial and direct with respect to the events which affect the public order of the vessel, though on occasion a concurrent jurisdiction may appropriately be honored with respect to these events as well as to those not affecting the public order of the vessel.

\section{A. Claims Reluting to Public Order of Ship}

In matters relating both to the discipline of the crew and to control of the passengers, it is imperative that the state of national character should have competence immediately to apply its authority. It is the current fashion to refer to the metaphor of the ship as a "floating bit of territory" as outmoded fiction, but, as in famous aphorism, a "fiction feigned is very near the simple truth." ${ }^{160}$ The very real community on board a ship is as much in need of the unified prescription and application of authority for the maintenance of public order as is a community on land. Every state demands this competence with respect to its ships and in turn recognizes similar competence in other states. ${ }^{101}$

This competence is commonly stated in the books in very broad terms. ${ }^{162}$

of course, that of The Lotus, decided by the Permanent Court, P.C.I.J., Ser. A, No. 10 (1927). Art. 11 of the Convention on the High Seas reverses the specifie holding of the Lotus Case, but does not disturb its more general significance.

160 While rejecting the usefulness of the "fiction of territoriality" of merchant vessels, Professor Higgins nerertheless states: "Il y a donc des liens étroits entre le naviro et l'État dont il acquiert la nationalité et ces liens entraînent comme conséquence l'application aux narires de la législation du pays du pavillon. C'est en vertu de cette législation que le capitaine exerce son autorité et qu'il la fait respecter. Le navire peut être un objet mobilier, un bien meuble, mais il est régi par des lois spéciales, et il est universellement admis qu'en haute mer, il doit échapper à tout contrôle autre que celui des autorités du pays du pavillon." Loc. cit. note 139 above, at 18 . See also St. Clair v. United States, 154 U. S. 134, at 152 (1894).

161 U.N. Legislative Series, Laws Relating to Jurisdiction over Crimes Committed Abroad or on the High Seas (U.N. Doc. ST/LEG/SER. B/2) (1952), and Supplement (U.N. Doe. ST/LEG/SER. B/8) (1959).

162 See, e.g., Colombos, op cit. note 133 above, at 222; Smith, The Law and Custom of the Sea 61 (3d ed., 1959) ; Fenwick, International Law 311 (3d ed., 1948).

A most recent confirmation of the competence of a state to apply its authority to events occurring on board ressels having its national character is provided by the decision in R. v. Governor of H. M. Prison Brixton, ex parte Minervini, [1958] 3 All E.R. 318; digested in 53 A.J.I.L. 447 (1959). An Italian national serving on board a Norwegian vessel muxdered a fellow crewman during a royage of the ressel and was subsequently arrested in England. In the ensuing proceedings, following a request by Norway for extradition on the basis of the Treaty of Extradition between the two countries, Lord Parker, C.J., ruled that the word "territory" as applied in the treaty should be in. terpreted as meaning "jurisdiction," and consequently Minervini's crime should bo dealt with as if it had been committed in Norway. In conclusion, Lord Parker said: "Accordingly, it seems to me that it matters not in this case whether the ship was in the middle of the North Sea, in the territorial waters of Norway, in the territorial waters of this country or in the territorial waters of any other Power; the Norwegian government had jurisdiction, and that is suffeient to enable these proceedings to be brought." [1958] 3 All E.R. at 321.

With respect to aircraft Kamminga observes: "With regard to breaches of discipline on board the aireraft, it is fairly generally agreed that these must be judged solely by 
Thus a conment, in the most recent draft of the American Law Institute, to a section devoted to the scope of jurisdiction, reads :

The principle is well established that a state may prescribe rules governing conduct aboard its vessels while they are on the high seas. The principle applies to all persons aboard, whether nationals or aliens. The United States and other maritime nations hold that conduct aboard is regulated by the law of the flag of the vessel even when it is in the waters of another state. ${ }^{\mathbf{1 6 3}}$

Similarly, Professor Hyde observed:

A State has the right to make reasonable application of its criminal code to its own vessels (private or public) when they are on the high seas, and, therefore, to punish the occupants who violate it. The relation of the State to the vessel when so eireumstanced justifies the assertion of jurisdiction. ${ }^{16 !}$

This perspective of a state's competence is so deeply respected that even when disorders aboard ship have occurred within the territorial domain of another country, the local authorities have been reluctant to interfere, except when asked to or when disorder threatened the value processes on shore. 'Thus in the celebrated Wildenhus' Case, where one Belgian member of the crew killed another Belgian member of the erew aboard a Belgian ship in an American port, C. J. Waite stated :

And so by comity it came to be generally understood among civilized nations that all matters of discipline and all things done on board which affected only the vessel or those belonging to her, and did not involve the peace and dignity of the country, or the tranquillity of the port, should be left by the local government to be dealt with by the authorities of the nation to which the vessel belonged as the laws of that nation or the interests of its commerce should require. ${ }^{165}$

the State whose nationality the aircraft possesses." The Aircraft Commander in Commercial Air Transportation 34 (1953). For more detail see pp. 136, 146 et seq.

103 Restatement, The Foreign Relations Law of the United States (Tentative Draft No. 2), 17 at 43 (1958). The relevant provisions of the Restatement read:

"17. A state has jurisdiction to preseribe rules governing:

(a) The conduct of all persons aboard national vessels while under the control of their commanding officer; ..." (Ibid. at 42.)

"18. A state has jurisdiction to enforce rules governing the conduct of persons:

(a) Aboard its national vessels while under the control of their commanding officer; ..." (Ibid. at 44.$)$

1641 Hyde, International Law 800-801 (2d rer. ed., 1945).

165120 U. S. 1, 18 (1887). When the public order of a ressel upon the high seas is threatened by a member of the crew or a passenger, the captain may immediately apply authority in order to protect life and property entrusted to him. In The Condor, Judge Hand stated with respect to the rôle of the captain: "Discipline on the sea is not like that on the land in ordinary industrial employments. The relations between master and men require an authority which is not necessary when both parties have immediate recourse to constituted authority. No doubt countless misery and brutality has arisen from the exercise of master's authority; but the substance of that authority still remains in civilized countries, and must remain, if men are put to sea for weeks, out of reach of the usual methods of keeping order." 196 Fed. 71, 74 (1912). For a more comprehensive coverage of this question see 1 Norris, Law of Seamen 82 et seq., Chs. 23 and 25 (1951). 


\section{B. Claims Relating to Events Not Affecting Public Order of Ship}

It is obvious that with respect to the great variety of events, including both deprivations and agreements as well as dispositive acts and matters affecting personal status, many different states will make many different claims based upon many different justifications and that many of these claims will be well founded in community policy. The fact that events of this type occur on board ship is just one factor among many others relevant to allocation of competence, and the multiple principles of jurisdiction in public and private international law aseribe a varying importance to different factors in different contexts. ${ }^{166}$ The state of national character may be accorded competence with respect to such events, but other states may be protected in a concurrent competence. This policy is relevant to each of the sub-categorizations of events which we have specified.

The competence of the state whose national character the vessel possesses is asserted in eategoric terms by many authorities. Thus Colombos states that "it is a generally recognised rule that the flag-State of the vessel is competent to deal with all matters eivil and criminal, which originate in the ship" while on the high seas. ${ }^{167}$

The competence of states other than the flag state has been asserted in countless instances on many different types of problems and this competence is commonly regarded as lawful when asserted under appropriate justification. Appropriate justification may be found in many different principles of jurisdiction, nationality, impact territoriality, passive personality, protective, "act of state," and so on.

\section{CLAIMS TO PROTECT COASTAL INTERESTS}

In lawful assertions of exclusive competence under international law a coastal state may apply its authority to the ships of any country. The importance of the national character of ships here is again to identify the states which may protect vessels against unlawful assertion of coastal competence. If a state's authority to question the lawfulness of such assertions of coastal competence with respect to its ships may be denied by unilateral challenge, the inclusive rights of states would be left with little or no protection. If states attributing national character are denied competence to protect, the effective powers of the coastal state over not only its internal waters but its territorial sea and contiguous zones could become even more comprehensive and absolute.

166 For an excellent survey of such relevant factors, see Lauritzen $v$. Larsen, $34 j$ U. S. 571 (1953), and Romero v. International Terminal Operating Co., 358 U. S. 354 (1959). For a thoughtful discussion of the problem, consult Bickel, "The Doctrine of Forum Non Conveniens as Applied in the Federal Courts in Matters of Admiralty," 35 Cornell Law Q. 12 (1949); Gilmore and Black, The Law of Admiralty 46-47 (1957). See also 2 Rabel, Conflict of Laws 346-351 (1947).

167 Colombos, op. cit. note 133 above, at 234 . See also 1 Beale, A Treatise on the Conflict of Laws 287-288 (1935). 
On every specific problem arising in each major subdivision below, the question is: Who can protect the ressel against abuses of coastal authority? The advantage of easy identification of such a vessel is in the economy and dispatch with which the protecting state may be ascertained. Any prolonged investigation of, or dispute about, the identity of the protecting state would seriously interfere with the smooth flow of ocean commerce. The importance of our detailed sub-categorization of problems is to indicate how frequent the oceasion for protection may be and how vital are the interests at stake.

Fortunately these preferred policies find universal acceptance in practice. The conclusiveness of a state's attribution of national character has been carried to the extent of allowing a state to protect a vessel to which it has attributed nationality even against a state whose individual nationals solely own and operate the ship. ${ }^{168}$

\section{A. Claims Relating to Internal Waters}

The books are full of accounts of controversies between states regarding the exercise of state authority over foreign vessels in internal waters, most of them in connection with claimed exemptions from jurisdiction and problems relating to the exercise of port authority over events aboard the vessel. ${ }^{1 \text { 'ix }}$ In disputes such as these, the exercise of the protective function by protest against an alleged impermissible assertion of authority by the port officials becomes of very considerable importance. The identification of the state authorized to make this protest is determined, both by customary law and many explicit agreements, by the national character of the ship concerned. ${ }^{170}$ The records fail to substantiate the notion that states are accustomed to deny objections by flag states to assertions of local authority on the ground that the flag-state connection with the vessel was not adequate to warrant the grant of nationality. ${ }^{1 \pi 1}$ To the contrary, in practice issues between territorial and flag states are commonly dealt with on the basis of the merits of the issue involved, and states do not seek to deny the basis for the attribution of national character.

168 Reference is made to the $I^{\prime} m$ Alone Case and the events connected with exclusion of trawling from Moray Firth, discussed above, pp. 62, 70 .

160 It is generally agreed that coastal states have full authority to prescribe and apply policy to events on board ressels in ports, except as agreements may limit coastal discretion. See Jessup, The Law of Territorial Waters and Maritime Jurisdiction 144194 (1927), and the numerous works there cited; Wildenhus' Case, 120 U. S. 1 (1887); for more recent practice see 2 Hackworth, Digest of International Law 208-224 (1941); The Lone Star, 1947 Annual Digest 84-90 (1951); Master Amiruzzaman and Others $v$. The Crown, 1953 Int. Law Rep. 171-172 (1957); Silberwacht v. Attorney General, ibid. at 153, 154-155; and American Law Institute, Restatement, op. oit. note 163 above, 34 .

170 Provision for competence over events on board foreign merchant vessels in port is commonly made in consular agreements. For illustrative provisions see U. S. agreements with the Philippines, Costa Rica, and the United Kingdom in 45 U.N.T.S. 38 (1949), 70 ibid. at 50 (1950) and 165 ibid. at 152-154 (1953).

y1 See sources cited in note 169 above. 


\section{B. Claims Relating to the Territorial Sea}

\section{Claims to Deny Access}

Since it has long been recognized that community use of the territorial sea of coastal states is often either virtually indispensable or convenient in very high degree, the promotion of inclusive interests of marked significance may be at stake in controversies concerning such an area. ${ }^{172}$ The protection afforded by the flag states to vessels passing through the territorial sea against abuse from coastal authority serves, accordingly, not only to save a particular vessel from harm, but also to establish and maintain a structure of prescription for protecting all who use the oceans. It is not surprising, therefore, that in this context the conclusiveness of the attribution of nationality is so taken for granted in the practice of states as to require no mention, much less emphasis. ${ }^{173}$ In particular, the issue of innocent passage is highly crucial in the case of fishing vessels, both because the potentiality of infringements upon coastal laws is so obvious, and because navigation close to the shore is peculiarly necessary for this type of craft. Yet one looks in vain for denials by the coastal state of the competence of the flag state to protect against coastal exercises of authority over those vessels. The issue is rather debated in terms of the actual interests at stake, and the procedural principles are taken for granted..$^{174}$

\section{Claims to Regulate Navigation of Ships}

Because coastal officials are more likely to know of the difficulties and dangers of transit through adjacent waters and the coastal state is most intimately affected by chronically unsafe conditions in such waters, it is clearly desirable that these officials exercise exclusive competence to regulate navigation through the territorial sea. The practice of states thoroughly accords with such policy and the importance of national character is again to insure protection against abuses of authority. ${ }^{175}$

172 Denial of access may be absolute, as in denial of innocent passage, or qualified, as in denial of passage that is allegedly non-innocent, but we do not differentiate these claims here because policy for present purposes is unaffected by the difference. For prescriptive formulations see Art. 14 and Art. 16(3) of the Convention on the Territorial Sea and Contiguous Zone, in 2 Official Records 133-134; 52 A.J.I.I. 837, 838 (1958).

173 The most important and authoritative secondary sources customarily used for reference upon territorial sea problems are: Fulton, The Sovereignty of the Sea (1911); Jessup, The Law of Territorial Waters and Maritime Jurisdiction (1927); Bustamante, The Territorial Sea (1930); 3 Gidel, Le Droit International Public de la Mer (1934); Raestad, La Mer Territoriale (1913); and the compilation in Crocker, The Extent of the Marginal Sea (1919).

174 Selak, "Fishing Vessels and the Principle of Innocent Passage," 48 A.J.I.L. 627 (1954).

175 Jessup, The Law of Territorial Waters and Maritime Jurisdiction 137-141 (1927); 1 Oppenheim, International Law 495 (8th ed., 1955, Lauterpacht); Restatement, cited note 163 above, $\$ 36$ (2) and Comment (c) to $\$ 36$ at 111 and 113. 


\section{Claims Relating to Control of the Ship}

Although recent agreement ${ }^{178}$ could alter the situation, disputes over this type of authority have been quite rare. ${ }^{177}$ It is widely assumed, both by officials and by writers, that the nationality of a vessel serves the function of identifying the state entitled to object to coastal attempts to assert control over a ship for purposes of eivil jurisdiction, and in the sole reported case involving this issue, United States v. Panama, no question was raised about the competence of Panama to confer its nationality on the ship concerned. ${ }^{178}$ It is clear, of course, that if states could easily deny the attribution of nationality in a situation of this kind, there would be no need for a structure of prescription which seeks to limit the exercise of coastal authority, for the simple reason that such authority would be complete and for all practical purposes beyond question.

\section{Claims to Exercise Authority over Events aboard Ship}

Although the general prescriptions for allocation of competence, phrased in terms of the impact of the events in question, are comparable to those for ships in port, ${ }^{179}$ the importance of the protective function would appear greater in this situation, since interference with passage through the territorial sea would have more drastic consequences. The evidence suggests that states do not, even in rare instances, seek to deny the national character of a vessel when the flag state protests the application of coastal law to a vessel in the territorial sea. The prohibition laws of the United States represent the most sweeping claim to apply local law in the territorial sea, and the states which protested, in the name of "inoffensive passage," sought to point out the detrimental effects of such application upon ships flying their flags. ${ }^{180}$ In concrete cases the United States never questioned

170 The International Convention Relating to the Arrest of Seagoing Ships, opened for signature on May 10, 1952, has been ratified by a few states, and relates to the arrest of vessels "flying the flag of a Contracting State in the jurisdiction of any Contracting State" for certain specified maritime claims. For text see U. S. Naval War College, International Law Situation and Documents 1956, 566 (1957); 53 A.J.I.I. 539 (1959).

177 The general conception prevailing among international lawyers is that the coastal state is not authorized to arrest a vessel passing through the territorial sea except " in respect of obligations or liabilities assumed or incurred by the ship itself in the course of or for the purpose of its voyage through the waters of the coastal State." Convention on the Territorial Sea and Contiguous Zone, Art. $20(2), 2$ Official Records 134. The 1952 Convention, if interpreted to extend to ships in passage, would permit arrests for a much broader eategory of elaims.

178 Compañia de Navegación Nacional (Panama) v. United States, in Report of B. L. Hunt, American and Panamanian General Claims Arbitration 765 (1934) (Dept. of State Arbitration Series, No. 6) ; 6 Rep. Int. Arb. Awards 382 (1955); 28 A.J.I.I. 596 (1934); Jessup, "Civil Jurisdiction over Ships in Innocent Passage," 27 A.J.I.I. 747 (1933).

175 Art. 19 of the Convention on the Territorial Sea and Contiguous Zone is the most recent authoritative formulation on this point. Art. 19 provides for coastal competence which is more limited than that which states claim in ports. Compare the provisions of Art. 19 with the sources cited above, note 169 .

180 Jessup, op. cit. note 175 above, 211-238, reviews some of the counterclaims; and see Jones, The Eighteenth Amendment and Our Foreign Relations (1933). 
the nationality of the ships concerned except where facts indicated the foreign registry was fraudulently obtained, as where there was knowledge of failure to comply with the foreign registration law. ${ }^{181}$ The deference accorded to the foreign attribution of nationality in these instances is representative of state practice in this situation.

\section{Claims to Deny Access to Non-National Aircraft}

Access to airspace above the territorial sea is largely dependent upon special agreement. ${ }^{182}$ Such agreements habitually accord access only to aircraft having the national character of the contracting parties. It will be recalled that the Chicago Convention provides in Article 17 that "[a]ireraft have the nationality of the State in which they are registered," and, in Article 18, that an "aircraft cannot be validly registered in more than one State."

\section{Claims to Exclusive Exploitation of Natural Resources}

There is, of course, no question that coastal states may exclude nonnationals from fishing in the territorial sea, and claims to exclude foreign vessels from this area are quite common. ${ }^{183}$ The chief dispute about these claims concerns the areas sought to be included within the territorial sea. ${ }^{184}$ As previously pointed out, Norway was careful to assert the right to protect its vessels against exclusion in the Moray Firth incident, when it was thought that the exclusionary authority might extend to the high seas, even though it was well known that the vessels were being used by British trawler owners merely to evade a British statute. ${ }^{185}$ The United States, the United Kingdom and numerous other states have been quick to defend against suspected excesses of otherwise acknowledged coastal authority, but there is no practice of denying these assertions on the basis that the objecting state had no authority to confer its nationality on the ships concerned. ${ }^{186}$

\section{Claims Relating to Contiguous Zones}

With respect to contiguous zones the policies specified above are even more important because assertions of authority under this concept may extend out over vast areas of the high seas and could cause immense disruptions in the processes of co-operative exploitation of the oceans. Vessels may avoid the intermal waters of a state which abuses its authority over vessels, but on occasion the exigencies of navigation may require vessels to

181 Jessup, op. cit. note 175 above, at 241-276.

182 See Arts. 1, 2, 3, 5 and 6 of the Chicago Convention on International Civil Aviation. For details, see Wassenbergh, Post-War International Civil Aviation Policy and the Law of the Air (1957).

183 Jessup, op. cit. note 175 above, passim; Riesenfeld, The Protection of Coastal Fisheries under International Law (1942); Leonard, International Regulation of Fisheries 9-11 (1944). 184 Leonard, op. cit. abore, at 12-34.

185 Fulton, op. cit. note 173 above, 721-728.

186 Notes 203 and 204 below, and accompanying text. 
resort to the territorial sea and, even more often, to the sometimes extensive area of contiguous zones.

\section{Traditional Claims}

There is a very substantial practice of, and consensus about, asserting authority beyond the territorial sea for special purposes and, since areas of inclusive use are affected and the doctrine of the freedom of the seas is so easily available for use, states are quick to act in defense of vessels affected by such authority. ${ }^{187}$ In this extensive practice of claim and counterclaim there is not the slightest indication of any consistent pattern of questioning the attribution of nationality to a particular vessel, although there are instances in which there would appear to be very slight connection between the flag state and the vessel. The I'm Alone Case, the facts of which were presented above, is a classic illustration. ${ }^{188}$ The United States introduced evidence that the beneficial ownership of the vessel was American, although it was registered in Canada. In an Interim Report, the Commissioners decided that the Tribunal was authorized to inquire into the question of ownership "as a basis for considering the recommendations which they shall make." 189 In the Final Report the Commissioners found

as a fact that, from September, 1928, down to the date when she was sunk, the I'm Alone, although a British ship of Canadian registry, was de facto owned, controlled, and at the critical times, managed, and her movements directed and her cargo dealt with and disposed of, by a group of persons acting in concert who were entirely, or nearly so, citizens of the United States, and who employed her . . ${ }^{190}$ [for rumrunning].

Although in the Interim Report the Commissioners had noted the possibility that this might "be a circumstance that should actuate the claimant Government in refraining from pressing the elaim, in whole or in part," nothing was said of this in the Final Report, and the Commissioners obviously did not regard this as sufficiently important for such purpose. The Commissioners, because of the fact of American ownership and control, declared that no compensation need be paid for the loss of ship or cargo, but that sinking the ship was an "unlawful act" for which the United States ought to make acknowledgment and apology and pay the Canadian Government. Thus American ownership and control meant that there

187 For review of policies and controversies consult 3 Gidel, op. cit. note 173 above, at 361-489; McDougal and Schlei, "The Hydrogen Bomb Tests in Perspective: Lawful Measures for Security," 64 Yale Law J. 648, at 666-681 (1955); Yntema, "Validity of Hovering Legislation in International Law," in Hearings before the House Committee on Ways and Means on H. R. 5496, 74th Cong., 1st Sess., pp. 82-124 (1935).

$1 \times 8$ Bee note 78 above.

189 The Commissioners noted three potential effects upon the Canadian claim of "indirect ownership and control" by American citizens: "whether it would be an answer to the Claim under the Convention, or whether it would go to mitigation of damages, or whether it would merely be a circumstance that should actuate the claimant Government in refraining from pressing the claim in whole or in part." 3 Rep. Int. Arb. Awards 1611,1614 (1949). 190 Ibid. at 1617-1618. 
could be no recovery for the vessel or cargo, but it did not follow that Canada was not entitled to extend its protection to the vessel and to collect for an illegal action causing harm to a vessel registered in Canada but having most intimate connection with the United States. ${ }^{191}$

\section{Claims to Exclusive Access to Fisheries beyond the Territorial Sca}

A limited number of unilateral claims of this type have been advanced by coastal states, ${ }^{192}$ but the most important attempts to establish this authority have been in the form of proposals for exclusive fishing rights in a contiguous zone which are explicitly coupled with proposals for extending the territorial sea a moderate distance. ${ }^{193}$ At the 1958 Conference the suggestion which received the greatest affirmative response was that of the United States, calling for exclusive fishing rights beyond the territorial sea, "provided that such rights shall be subject to the right of the vessels of any State whose vessels have fished regularly in that portion ..." to fish in the exclusive area. ${ }^{194}$ The conference records are barren of any suggestion that states might be authorized, if this proposal were adopted, to question the competence of the flag state to attribute its national character to a fishing vessel.

191 This case has been interpreted to stand for the proposition that the state may not extend "protection" where ownership and control rests in the hands of citizens of another state. See Watts, loc. cit. note 75 above. The confusion which led to this misunderstanding of the $I^{\prime} m$ Alone Case appears to arise from failure to note that the Tribunal, in refusing to require payment for the loss of the vessel and cargo, was merely giving effect to its finding of U. S. ownership and control by mitigating damages, as it suggested it could do in its Interim Report, but was not suggesting that Canada should refrain from pressing the claim, an alternative the Commissioners also thought might follow from this fact. Indeed, the requirement of payment to the Canadian Government would seem to underscore the right of that state to assert claims on behalf of vessels of its national character, irrespective of ownership. In any event, if the fact of American ownership and control had been thought to warrant denial of Canada's right to press a elaim against the United States, as Mr. Watts suggests the Commissioners decided, it is reasonable to suppose that the Commissioners could have found a better way to express this conclusion than in requiring the United States to pay Canada $\$ 25,000$ for sinking the $I^{\prime} m$ Alone.

192 Brazil and Yugoslavia (U. S. Naval War College, International Law Situation and Documents 1956, 444, 500-501 (1957)); the claims of Chile, Ecuador and Peru are also illustrations, if one accepts the contention of these states that their 200-mile claims were not efforts to widen the territorial sea. 1 Verbatim Record of Debate in the 6th Committee of the General Assembly 32 (U.N. Doc. A/Conf.13/19) (1957). And see 2 Official Records 6-7, 32-33, 61-62, for statements by representatives of these states seeking to emphasize the "limited" authority claimed in the 200-mile zones.

193 See Report of the First Committee, 2 Official Records 115.

194 U.N. Doc. A/Conf. 13/L.29, in 2 Official Records 125-126. In Plenary Session this proposal received 45 affirmative rotes, with 33 against, and 7 abstentions. 2 Official Records 39. The Canadian proposal, also providing for an exclusive fishing zone beyond the territorial sea but without mentioning a limit for the latter, was approved in the First Committee, and in Plenary Session received 35 farorable rotes, with 30 against, and 20 abstentions. Ibid. 
3. Claims to Exclusive Exploitation of the Natural Resources of the Continental Shelf and Other Submarine Areas

There is no evidence in past experience of limited exclusive authority to indicate that states have sought to deny the national character of vessels in this context. ${ }^{195}$

\section{Claims Relating to Conservation}

Whether claims to conserve fishery resources are made unilaterally, as in the American Proclamation of $1945,{ }^{196}$ or multilaterally, as in the 1958 Conservation Convention, ${ }^{107}$ the national character of fishing vessels serves functions indispensable to successful and peaceful operation of the regulatory schemes projected. In either case the conclusiveness of the attribution of nutionality is so widely assumed that the question is seldom, if ever, raised. The elaims to exclusive competence for conservation purposes beyond the territorial sea, either prohibiting foreign fishing or imposing regulations thereon, are not new, but the practice of states is to be scrutinized in vain for evidence supporting the expectation that states may deny the competence of the flag state to attribute nationality to a vessel. ${ }^{198}$ Indeed the situation is quite the opposite: the deference to this competence is so marked that regulatory schemes have on occasion foundered because of successful evasive efforts of the citizens of the regulating state in seeking the shelter of the flag of another state. ${ }^{199}$ The recognized conclusiveness of attributions of national character to fishing vessels is merely emphasized further by the many expressions of support for permitting exclusive coastal competence for conservation purposes, for such sentiments derive from recognition that, as Gidel puts it, "the system of conventions is at the mercy of individual egoism." 200

105 Hurst, "Whose is the Bed of the Sea?" 4 Brit. Yr. Bk. Int. Law 34 (19231924); Mouton, The Continental Shelf 138-161 (1952); Waldock, "The Legal Basis of Claims to the Continental Shelf," 36 Grotius Society Transactions 115, 118 (1951). See also Art. 2, Convention on the Continental Shelf, 2 Official Records 142; 52 A.J.I.L. 858 (1958).

196 The Proclamation of Sept. 28, 1945, perhaps made limited assertion of exclusive competence, since the U. S. offered to establish conservation zones by agreement with the states where fishing "activities have been or shall hereafter be legitimately developed by nationals of the United States and nationals of other States. . . " The exclusive claim seems to reside in the instance where the fishing activities had been maintained solely by Americans, and others later sought to enter the same fishery. For text, see U. S. Naval War College, International Law Situation and Documents 1956, 434-435 (1957); 40 A.J.I.I. Supp. 46, 47 (1946). See Bingham, "The Continental shelf and the Marginal Belt," 46 A.J.I.L. 173 (1946).

197 Convention on Fishing and Conservation of the Iiving Resources of the High Seas, 2 Official Records 139; 52 A.J.I.L. 851 (1958).

198 Leonard, International Regulation of Fishing (1944); Fulton, The Sovereignty of the Sea 604-649, 691-698 (1911); Tomaserich, International Agreements on Conservation of Marine Resources (1944).

199 Tomasevich, op. cit. at 87; Leonard, op. cit. at 49, 90, 104-106.

200 U.N. Secretariat, Memorandum on the Regime of the High Seas 44 (U.N. Doc. A/CN.4/32) (1950). 
The importance of the conclusiveness of attributions of national character to fishing vessels is to be seen in the frequent practice, once a convention on conservation is agreed upon, of placing enforcement powers in the hands of officials of the flag state of a vessel suspected of violations.201

Finally, attention may again be called to the 1958 Conservation Convention. As previously noted, the structure of the convention with respect to the invocation of authority for challenging the permissibility of proposed conservation measures depends largely on the national character of fishing vessels affected by such measures. Article 14 provides that for purposes of various articles in the convention dealing with the effects upon fishing ressels of an actual or proclaimed conservation program, "the term 'nationals' means fishing boats or eraft of any size having the nationality of the State concerned, according to the law of that State, irrespective of the nationality of the members of their crews." 202

\section{Claims Relating to the Delimitation of Boundaries}

If states which make questionable claims to the delimitation of water boundaries are conceded authority unilaterally to challenge the competence of other states to protect ships to which they have attributed their national character, such states might of course postpone indefinitely decision as to the legality of their questioned delimitations. This is the way the AngloNorwegian Fisheries ${ }^{203}$ Case came up, and there would indeed be no need for its elarification of fundamental policies, if it is made too difficult to test states' exclusive interpretations of these policies.

Numerous claims to exclusive fishing rights have, of course, affected foreign vessels and have been controverted on the ground that the area concerned could not lawfully be included within the territorial sea or internal waters of the claiming state. ${ }^{204}$ While these counterclaims, put forward in protection of inclusive fishing rights, have created very considerable dispute, none has arisen concerning the nationality of affected vessels. There is not the faintest sign of a practice of rejecting counter-

201 Leonard, op. cit. note 198 above, at 38-39, 91, 111-112.

2022 Official Records 141.

203 Judgment of Dec. 18, 1951, [1951] I.C.J. Rep. 116; 46 A.J.I.L. 348 (1952). Waldock, "The Anglo-Norwegian Fisheries Case," 28 Brit. Yr. Bk. Int. Law 114, 117124 (1951), outlines the historical background of interference by Norway with foreign vessels.

20* Indeed, practically all objections to exclusive fishing claims relate to the boundary problem. See Riesenfeld, op. cit. note 183 above, at 146, 157 ; Fulton, op. cit. note 173 above, at 650-740. The North Atlantic Fisheries Case and the Anglo-Norwegian Fisheries Case both dealt principally with delimitation of sea boundaries. Difficulties over disputed extensions of the territorial sea so affected American fishermen that legislation was adopted in 1954 for reimbursing fines imposed upon them when the United States did not recognize the rights asserted by the claiming state. 68 Stat. 883 .

Desirable community policy concerning the width of the territorial sea, with detailed examination of factors relevant to policy with respect to exclusive fishing rights, is discussed in McDougal and Burke, "The Community Interest in a Narrow Territorial Sea: Inclusive versus Exclusive Competence over the Oceans," 45 Cornell Law Quarterly, No. 2 (Winter, 1960). 
claims on behalf of foreign fishing vessels on the ground that the objecting state had no authority to confer its nationality upon the vessels concerned. The Anglo-Norwegian Fisheries Case illustrates one important way of contesting claimed sea boundaries and it is typical in the sense that the claims and counterclaims centered upon the question of permissible boundaries and not upon any issue of competence to fix national character on ressels affected by the claimed delimitation scheme.

\section{CLAIMS RELATING TO SEIZURE OF SHIPS FOR PURPOSES OF CIVIS JURISDICTION}

It is a practice common to both common-law and civil-law countries, and a practice fully authorized under principles of jurisdiction in public and private international law, that the mere physical presence of an asset within the territorial domain of the exclusive public order of a state is sufficient to confer competence upon that state to apply authority to many different types of controversies. ${ }^{205}$ It would appear most compatible with the policy of harmonious and economic exploitation of the oceans that states should assert such authority, certainly in the territorial sea, only under the most demanding conditions. ${ }^{206}$ It may be emphasized that, even when states do assert competence to arrest ships for purposes of establishing jurisdiction, such assertion need not be regarded as a denial of the national character of the vessel. The only premise necessary to decision is that factors other than nationality are more important.

There is no doubt that states are permitted by customary international law to arrest or detain vessels, irrespective of flag, for the purpose of the exercise of judicial authority in application of local or foreign policy to them. The practice of states varies greatly on the competence accorded local courts over events occurring elsewhere involving foreign vessels, some states placing great emphasis upon the nationality of the parties or of the ship, ${ }^{207}$ and others entertaining suit merely on the ground of the physical presence of an asset. ${ }^{208}$ Despite this variance, the practice of leading maritime states, extending judicial authority to events occurring anywhere on the globe, has not been successfully protested by other states and undoubtedly falls within the limits of permissible competence. ${ }^{209}$ In the United States, for example, "The courts of the United States take jurisdiction, subject to some reservations imposed by their own application of the doctrine of forum non conveniens, of suits on maritime elaims arising out

205 Wolff, Private International Law 64-72 (2d ed., 1950); Dicey's Conflict of Laws 213-214 (7th ed., gen. ed., Morris, 1958).

208 Jessup, "Civil Jurisdiction over Ships in Innocent Passage," 27 A.J.I.L. 747 (1933). Art. $20(2)$ of the 1958 Convention on the Territorial Sea and Contiguous Zone provides for a very limited coastal competence to levy execution upon or to arrest a ship for a civil proceeding while it is merely passing through the territorial sea between outside points. 2 Official Records 134; 52 A.J.I.L. 839 (1958).

207 Wolff, op. cit. note 205 above, at 54, 60-61; Coffey, "Jurisdiction over Foreigners in Admiralty Courts," 13 Calif. Law Rev. 93, 99 (1925).

208 Wolff, op. cit. note 205 above, at 74; Robinson, Admiralty Law 14-20 (1939); Coffey, loo. cit. above, at 94 . 209 Coffey, loc. cit. 
of transactions and oceurrences anywhere in the world." 210 In England the mere presence of a vessel in an English port is sufficient to found jurisdiction of the courts..$^{211}$

In contrast to customary international law, which imposes no limit. certain agreements concerning the arrest of vessels for specific maritime claims may make the matter of the national character of a ship important in their application. Thus the International Convention Relating to the Arrest of Seagoing Ships limits the scope of the claims for which vessels may be arrested, and those benefits of the treaty extend only to vessels flying the flag of contracting states. Vessels flying the flag of non-contracting states may be arrested for any claim permitted by the law of a contracting state in accordance with general maritime law. ${ }^{212}$

\section{CLAINIS WITH RESPECT TO EVENTS PRIMARILY AFFECTING VALUE PROCESSES WITHIN TERRITORIAU, COMMUNITIES AND NOT DIRECTLY RELATED TO TEE ENJOYMENT OF THE HIGE SEAS}

In addition to the above-mentioned claims which states make against each other about interactions directly affecting their common enjoyment and shared competence over the oceans, states also make a great many claims about interactions which only indirectly affect such enjoyment and competence. These claims include those relating to agreements and deprivations in many different value processes in their territorial communities, claims concerning activities of private associations seeking wealth and other values by operations and transactions across state boundaries, claims with respect to family relationships, claims relating to management of resources, and so forth. ${ }^{213}$

Sometimes states having effective control over persons or property make direct claims against other states or the general community of states to prescribe and apply policy to certain particular events, ${ }^{214}$ but on other occasions, when not disposing of immediate effective control, a state may make claim against other states, who do have such control, to defer to, or honor, its authority over the events in question. ${ }^{215}$ These two different

210 Gilmore and Black, The Law of Admiralty 46-47 (1957).

211 Wolff, op. cit. note 205 above, at 74; Dicey, op. cit. note 205 above, at 213-214; Coffey, loc. cit. note 207 above, at 94 .

212 Arts. 1 and 8. The text of the treaty is in U. S. Naval War College, International Law Situation and Documents 1956, 566 (1957), and 53 A.J.I.L. 539 (1959).

213 More specific illustration would mention, for instance, the effects of contracts and torts occurring within another territorial community, taxation of nationals and non. nationals, labor-management relations, and entry of persons and goods.

214 This involves a claim not only to apply policy but also a claim to decide that it is local policy which is applicable. The general subject matter embraces all of private international law. See, generally, Wolff, op. cit. note 205 above; Katzenbach, "Conflicts on an Unruly Horse: Reciprocal Claims and Tolerances in Interstate and International Law," 65 Yale Law J. 1087 (1956) ; Ehrenzweig, Conflict of Laws (1959).

215 Comment, "Act of State' Immunity," 57 Yale Law J. 108 (1947-1948); Wolff, op. cit. note 205 above, at 249-274; Comment, "The Jurisdictional Immunity of Foreign Sovereigns," 63 Yale Law J. 1148 (1954); Katzenbach, 65 ibid. at 1128-1139 (1956). 
kinds of claims may, of course, be contraposed by different states in one and the same controversy, and decision may require choice between the directly opposing assertions of authority for prescription or application or both.

The primary demands by states having some effective control over relevant persons or property to preseribe and apply policy to particular events are asserted with respect to both events occurring within their territory and events occurring beyond such territory. Concerning events which occur within their territorial boundaries, states quite naturally seek to protect their resource base and the integrity and efficiency of their internal value processes. Concerning events occurring beyond their boundaries, states may make claim, as we have already seen in the discussion of interactions directly affecting shared use of, and authority over, the oceans, to protect national vessels wherever they may be, and to protect certain interests regarded as universal to all mankind, such as the suppression of piracy. States may also make claim, in the context of interactions which have but incidental impact on common use of, and competence over, ocean areas, to protect the territorial base or community processes from external attack or deprivation, to protect substantial state interests (as in the integrity of their currency) against external injury, to control and to protect individual and corporate nationals while abroad, and to promote fundamental community interests shared by all peoples, such as assuring compliance with prescriptions about resort to, and use of, coercion.

The important interactions giving rise to all these claims obviously may have effects, varying in scope and intensity of impact, upon several territorial communities. The most general community objective is, accordingly, that of allocating competence to prescribe policy among the affected states in a way to maintain the efficacy and substantial fairness both of the authoritative power processes by which control over value changes is exercised and of the interdependent social processes of which the preeipitating events are but one segment. Professor Yntema has phrased the point suecinctly:

In a highly integrated world economy, politically organized in a diversity of more or less autonomous legal systems, the function of conflict rules is to select, interpret and apply in each case the particular local law that will best promote suitable conditions of interstate and international commerce, or, in other words, to mediate in the questions arising from such commerce in the application of local law..$^{216}$

The "essential policy considerations peculiar to conflicts law" he subsumes under the principles of "security" and "comparative justice." 217 The latter refers, presumably, to such standards as those embodied in the familiar general principles of law recognized in mature legal systems. Concrete implementation of these policies in the immediate context clearly

216 Yntema, "The Objectives of Private International Law," 35 Canadian Bar Rev. 721,741 (1957).

217 Ibid, at 735 . 
requires use of a multifactor analysis which will permit appropriate weighing of all considerations relevant to identification of the local policy which will "best promote" the end in view. The fact that the attribution of national character by one state to a ship is but one factor to be taken into account in this process does not mean, it must be emphasized, that national character is not a most important factor bearing upon policy, nor does a determination that national character is not conclusive of decision constitute a denial of the exclusive competence of the flag state to attribute its nationality. In sum, appropriate mutual tolerance requires that states exercise a very delicate discretion in their application of local policy in situations in which national character is a relevant factor, even in problems of this type.

The practice by which states make these indicated policies effective with respect to events which have simultaneous impact upon different territorial communities, and also indirectly affect use of the oceans, is, of course, written large and often both in judicial decision and in the observations of commentators upon private international law and admiralty. Detailed recapitulation of familiar knowledge is unnecessary. For succinct but expressive summary of the considerations which characteristically move decision-makers when faced with problems of this type, the opinion of Mr. Justice Jackson in Lauritzen v. Larsen is already considered classic :

International or maritime law in such matters as this does not seek uniformity and does not purport to restrict any nation from making and altering its laws to govern its own shipping and territory. However, it aims at stability and order through usages which considerations of comity, reciprocity and long-range interest have developed to define the domain which each nation will claim as its own. Maritime law, like our municipal law, has attempted to avoid or resolve conflicts between competing laws by ascertaining and valuing points of contact between the transaction and the states or governments whose competing laws are involved. The eriteria, in general, appear to be arrived at from weighing of the significance of one or more connecting factors between the shipping transaction regulated and the national interest served by the assertion of authority. It would not be candid to claim that our courts have arrived at satisfactory standards or apply those that they profess with perfect consistency. But in dealing with international commerce we cannot be unmindful of the necessity for mutual forbearance if retaliations are to be avoided; nor should we forget that any contact which we hold sufficient to warrant application of our law to a foreign transaction will logically be as strong a warrant for a foreign country to apply its law to an American transaction. ${ }^{218}$

Similarly, Mr. Justice Frankfurter, in Romero v. International Terminal Operating Company, offered comparable formulation in referring to "the accommodations that become relevant in fair and prudent regard for the interests of foreign nations in the regulation of their own ships and their

218345 U. S. 571, 582 (1953); 47 A.J.I.L. 711 (1953). For discussion generated by this decision, see Gilmore and Black, The Law of Admiralty 386-394 (1957). See also 2 Norris, The Law of Seamen 348-361 (1952) and 1958 Cumulative Supp. 147-149. 
own nationals, and the effect upon our interests of our treatment of the legitimate interests of foreign nations." 219

\section{CLAIMS RELATING TO MODALITIES OF PROOF OF THE NATIONAL CHARACTER OF SHIPS}

It is the act of a state in attributing its national character to a vessel which is important in all instances in which the national character of a vessel is either controverted or question is raised about the relevance to decision of that national character. With respect to the modalities of proof of this act, relevant policy considerations embrace two different interests : first, the interests of all parties, both claimants and challengers, in the maintenance of secure, economic and quick methods for establishing the act of attribution; secondly, the interests of states other than the attributing state, and non-state parties, in a record of attributions adequate to put them on notice. Notice is indispensable both to prevent double attributions and to protect parties from being taken by surprise in financial transactions. Of the various modalities suggested for proof of attribution, such as registration, flag and documentation, registration would appear to be the most economic alternative. It is least susceptible of fraudulent manipulation. Flags, in contrast, can be run up and down with great speed, and documentation ean be easily falsified; hence neither flag nor documentation would seem to guarantee the desired degree of certainty in establishing the act of attribution and in identification of the national character of the vessel. None of the many suggested references for genuine link, it may be noted, have any bearing, reliable or unreliable, upon this task of proving a state's act of attribution of national character to ships. Registration should be accompanied, as it customarily is, by documentation, and every precaution should be taken against false documentation. When discrepancy appears between registration and documentation, the former, because of the greater reliability it affords, should prevail.

\section{A. Claims with Respect to Registration}

The best evidence of the surpassing reliability of registration as a mode of proving national character may be found in both the universality of its

21979 S. Ct. 468,486 ; 358 U. S. 354, 384 (1959).

The impact of the genuine link requirement upon applieation of Ameriean labor legislation to foreign flag ressels is being contested by labor and ship-owning groups. See Memorandum to the Department of State and to the General Counsel of the National Labor Relations Board from the American Committee for Flags of Necessity, Oct. 30, 1959. See, for reply to this Memorandum, Reply Brief of Charging Party in West Indies Fruit and Steamship Company, Ine. and Seafarers' International Union of North America, Atlantic and Gulf District, AFL-CIO, N.L.R.B. Case No. 15-CA-1454, dated Dec. 10, 1959.

For an excellent, comprehensive inquiry into the problem of American labor laws and flags of convenience, with explicit weighing of inclusive and exclusive interests, see Comment, "The Effect of United States Labor Legislation on the Flag of Convenience Fleet: Regulation of Shipboard Labor Relations and Remedies Against Shoreside Pirketing," 69 Yale Law J. 498 (1960). 
use ${ }^{220}$ and in the unquestioned success of the maintenance of community policies which states have thereby achieved.

Registration was practiced, one author asserts, as early as in the days of ancient Rome..$^{221}$ In its modern sense its appearance is usually associated with the Navigation Acts of the 17th century which made registration of British ships compulsory. ${ }^{222}$ It is significant that one of the first statutes of the young American Republic was the Registry Act of 1792, providing for registration, enrollment and licensing of vessels. ${ }^{23}$ The Supreme Court of the United States, in the case of The Mohawk, interpreted the function of registration in these words :

The purpose of a register is to declare the nationality of a vessel engaged in trade with foreign nations, and to enable her to assert that nationality wherever found. The purpose of an enrollment is to evidence the national character of a vessel engaged in the coasting trade or home traffic, and to enable such vessel to secure a coasting license. ${ }^{224}$

The practice of registration is so universal ${ }^{225}$ that among the relevant statutes of sixty-five different countries reproduced in the U.N. collection of laws concerning the nationality of merchant vessels, not a single one can be found which does not require at least some kind of registration. ${ }^{228}$ The

220 With respect to state vessels, those engaged in commerce are, of course, registered, whereas warships are recorded in special naval lists.

221 Williams, "Function of Evidence in Roman Law," 20 Law Magazine \& Review 73 (4th ser.), quoted in Rienow, op. cit. note 143 above, at 155.

222 Abbott, A Treatise on the Law Relative to Merchant Ships and Seamen 35, note (c) (1822); Desjardins, Introduction historique à l'étude du droit commercial maritime 157 (1890). For details with respect to these Navigation Acts see Reeves, History of the I aw of Shipping and Navigation (1792). A critical appraisal of the human and other factors behind this British experiment is provided by Harper, The English Navigation Laws (1939).

223 The current text provides: "Vessels registered pursuant to law and no others, except such as shall be duly qualified according to law for carrying on the coastal or fishing trade, shall be deemed vessels of the United States, and entitled to the benefits and privileges appertaining to such vessels ..." 46 U.S.C. $\$ 221$ (1952).

In the Merritt Case, the Supreme Court of the United States unequivocally declared: "The Merritt is not a vessel of the United States.... [T] That she was owned by citizens of the United States did not make her a vessel of the United States. By the statute of 1792 only ships which have been registered in the manner therein prescribed shall be denominated or deemed ressels of the United States, entitled to the benefits or privileges appertaining to such ships. There is no allegation that the Merritt had been so registered." 84 U. S. (17 Wall.) 582,585 (1873).

22470 U. S. (3 Wall.) 566, at 571 (1865).

225 Thus Higgins observes: "La seule condition qui soit généralement exigée dans tous les pays, c'est l'inscription du navire sur le registre tenu par les autorités désignées à cet effet. . . ." Higgins, "Le Régime Juridique des Navires de Commerce," 30 Hague Academy Recueil des Cours 21 (1929, V). Similarly, Diena, at one time Vice Chairman of the League of Nations Committee for the Codification of International Law, "Prin. cipes du Droit International Privé Maritime," 51 Hague Academy Recueil des Cours 409. at 426 (1935, I).

226 United Nations Legislative Series, Laws Concerning the Nationality of Ships (U.N. Doc. ST/LEG/SER.B/5) (1955), and Supplement to Laws and Regulations on the Regime of the High Seas and Laws Concerning the Nationality of Ships 113 et seq. (U.N. DOC. ST/LEG/SER.B/8) (1959). 
only important difference in this respect between states concerns the tonnage of the vessels which must be registered, minor craft not intended for ocean navigation being usually exempted. As already indicated, numerous multilateral and bilateral international agreements contain reference to registration as a mode of ascertaining the vessels to which they apply.227 Thus, for example, the Load Line Convention of 1930 provides in Article 3(a):

A ship is regarded as belonging to a country if it is registered by the Government of that country.228

It may be of interest to note that at the Twenty-First Session of the International Labor Conference, the supreme body of the International Labor Organization, a special committee was appointed to search for the "most appropriate criterion for the demarcation of the scope as regards vessels of international Conventions defining standards to be enforced on board in the public interest." 229 This committee found "registration as the most appropriate criterion," ${ }^{230}$ which resulted in the inclusion of this standard in five maritime labor conventions adopted at that session. Mr. C. W. Jenks, a high official of the International Labor Organization, commenting upon the work of the Twenty-First Session, after a careful survey of international practice, concluded that "in view of the desirability of securing the greatest possible uniformity" with respect to the determination of vessels for which parties to the I.L.O. conventions assume responsibility, "registration will perhaps commend itself as the most satisfactory criterion." "231

Registration serves, as pointed out above, still another highly important purpose, comparable to that served by public books about land, as conclusive and reliable evidence of various private rights in the ship. As an illustration we quote from a Swedish statute of 1891:

Similarly aviation statutes of numerous countries require registration. Thus the Air Transport Act (Luftfahrgesetz) of Austria of Dee. 2, 1957, provides in Art. 15 (1): "Sont de nationalité autrichienne tous les aéronefs civils enregistrés au registre des aéronefs ( $\$ 16)$ ainsi que tous les aéronefs de l'Armée fédérale. Ms doivent porter les signes distinctifs autrichiens." 12 Rev. Française de Droit Aérien 358, 362 (1958).

227 It will be recalled that countless international treaties of commerce and navigation accept the ascription of the party's nationality to a vessel as conclusive. However, in some postwar American commercial agreements there is a clause which allows the contracting parties to deny the benefits of the agreement to companies in which the controlling interest belongs to nationals of a third country, not a party to the agreement. Commenting upon the meaning of such a clause, Mr. Walker, an official of the Department of State, observes: "It cannot be invoked in a manner to deny recognition of nationality and legal existence, or of access to courts, regardless of the dominant real interests in the company." Walker, "Provisions on Companies in United States Commercial Treaties," 50 A.J.I.I. 373, 388 (1956). Mr. Walker even suggests that the policy of conclusiveness has proved so advantageous with respect to ships that it might bo appropriately employed in greater degree with respect to companies.

2285 Hudson, International Legislation 639 (1936).

$2 * 2$ Jenks, "Nationality, the Flag and Registration as Criteria for Demarcating the Scope of Maritime Conventions," 19 Journal of Comp. Leg. and Int. Law 245 (1937). $280 \mathrm{Tbid}$. 231 Ibid. at 252. 
Article 2. A register shall be kept of all Swedish ships of 20 tons Register burden or upwards intended for use in merchant shipping or for the conveyance of passengers and shall contain for each such ship all the details which are deemed requisite for its identification, as well as information respecting ownership, the nature of the acquest by the registered owner and the time when the ship was registered or when change of ownership was entered; and a certificate shall be issued to every ship when entered in the Register, and such certificate shall accompany the ship.

When an application for the registration of a ship is made, a certificate shall be produced showing when, where, and by whom the ship was built, or, in the event of the ship having been foreign property, it shall be proved that the right of the foreign owner has been transferred to the person requiring to be registered as owner thereof. On the registration of a ship a certain number shall be allotted to the ship, and that number may not subsequently be altered or allotted to any other ship.... If notice is given of a change in the ownership of a ship entered in the Register, but if it is found that the alleged owner thereof cannot be entered in that capacity, an entry shall nevertheless be made in the Register setting forth his name, the nature of his acquest, and the date of the notice so given. No ship entered in the Register may be removed from the same except when the ship has been lost, or broken up, or otherwise destroyed, or may, in accordance with (article 258) be considered lost, or, after having sustained damage, is condemned, or has ceased to be Swedish. ${ }^{232}$

At the 1958 Geneva Conference on the Law of the Sea, Mr. Breuer, a delegate of the German Federal Republic, stressing the desire of his government to attain an "exact definition" of the genuine link, made this observation :

Rules should be drawn up concerning the registration of ships, for it was registration which established the link between State and ship. ${ }^{283}$

232 Laws Concerning the Nationality of Ships, op. cit. note 226 above, at 162-163. The Chinese Shipping Registration Act of 1930 (as amended in 1946 and 1947) is even more explicit:

"Article 2. A ship shall be registered by the shipping office of its home port.

"Article 3. All matters relating to the preservation, creation, transfer, variation, limitation, disposal or extinction of the following interests in ships shall be registered:

(a) Ownership;

(b) Charges;

(c) Charter.

"Article 4. A registerable claim relating to a ship silll not lie against a third party unless it has been registered." Ibid. at 24.

Compare also corresponding acts of Finland (p. 50), Greece (p. 68), Ethiopia (p. 47), Norway (p. 124).

2334 Official Records 67. It is possible that the International Court of Justice may give an opinion on the significance of registration for national character in connection with the decision of the Inter-Governmental Maritime Consultative Organization (IMCO) on constituting its Maritime Safety Committee. The IMCO decided at its inaugural session in 1959 that for purposes of membership on this Committee the requirement of its constitution that at least eight members must be the "largest shipowning nations" was not to be interpreted to refer to the amount of tonnage registered but rather to the amount of tonnage owned by a state or its nationals. The practical effect of this decision was to exclude Panama and Liberia from membership on the Committee. The IMCO then agreed to ask the International Court for an advisory opinion on the question whether the Committee had been constituted in accordance 
Unfortunately, this sound suggestion for determining the national character of vessels was not accepted in the Convention on the High Seas.

\section{B. Claims with Respect to Documentation}

The fact of a state attributing its national character to a vessel as expressed in registration is commonly recorded in documents kept on board the vessel. The importance of this documentation as convenient evidence of registration is attested again by practice centuries old. Thus the Treaty of Peace and Friendship of 1667 between Great Britain and Spain refers to a "passport or sea-papers" which vessels of the contracting parties should keep on board to be protected from "molestation." 234 Similarly, in the Treaty of Navigation and Commerce concluded in 1713 between France and England, reference is made to a ship's "sea letters or passports" as a mode of attesting the national character of the vessels belonging to the parties. ${ }^{235}$ References to a ship's documents as evidence of its national character can be found in countless subsequent bilateral and multilateral agreements concluded by many other states, including the peace treaties following World War I. Gidel cites the following as a typical example of a provision relating to documentation in treaties concluded between France and a number of other states:

La nationalité des navires sera reconnue par les deux H.P.C. conformément aux lois et règlements de chacune d'elles et sera constatée d'après les documents et patents se trouvant à bord et établis par les autorités compétentes. ${ }^{236}$

The great practical importance of documents is illustrated by a decision of the United States Supreme Court in the MLerritt case, a controversy involving an American-owned, foreign-built vessel without doeuments, which was engaged in commerce between Canada and the United States. Mr. Justice Hunt bluntly declared:

The case does not show that the Merritt has any of the evidences of being a British ship. She produces no register, or certificate, or document of any kind to entitle her to make that claim. . . .

The documents a vessel carries furnish the only evidence of her nationality. ${ }^{237}$

A vessel without documents can hardly engage in any kind of lawful activity ; ${ }^{238}$ it may not only be denied entry to foreign ports, but it runs a serious risk of being suspected of piracy. ${ }^{239}$

with the IMCO Conrention. See Jessup, "The United Nations Conference on the Law of the Sea," 59 Columbia Law Rev. 234, 257 (1959).

284 2 Chalmers, A Collection of Treaties between Great Britain and Other Powers 13-14 (1790). 2352 ibid. at 404 .

2sB I Gidel, op. cit. note 173 above, at 89-90.

ะ37 81 U. S. (17 Wall.) 582,587 (1873).

$\because 38$ Art. 6 of the Shipping Act of Japan of 1899, amended to 1954, contains a typical provision: " ... no Japanese ship may wear the Japanese national flag or be operated before the certificate of nationality ... has been applied for and obtained." Laws Concerning the Nationality of Ships, op. cit. note 226 above, at 91 .

2391 Gidel, op. cit. note 173 above, at 84. In Badger v. Gutierez, Mr. Justice Miller said: "It is to be understood that every vessel of the United States, which is afloat, is 
Each state is free to determine for itself the number and character of ship's documents. ${ }^{240}$ In time of peace such documents enjoy international recognition and will in nearly all cases be sufficient and reliable proof of the true national character of the vessel. ${ }^{241}$ Moreover, as the case of The Virginius illustrates, the state which has issued the documents in proof of a ship's national character is appropriately regarded as the sole judge when it comes to deciding whether they have been lawfully obtained.

Despite the admitted practical importance of documentation, the ease of falsification and alteration suggests that documentation alone ought not to be regarded as determining national character. Yet this seems to be the import of the 1958 Convention on the High Seas, which provides in Article 5, as did the recommendation of the International Law Commission, that:

1. Each State shall fix the conditions for the grant of its nationality to ships, for the registration of ships in its territory, and for the right to fly its flag. Ships shall have the nationality of the State whose flag they are entitled to fly.

After reference to a "genuine link," the article continues: "Each State shall issue to ships to which it has granted the right to fly its flag documents to that effect."

Although by no means unambiguous, since the first sentence appears to envisage conditions for the grant of nationality other than the right to fly the flag, the meaning of this appears to be that ships must be regarded as having the nationality of the state issuing documents that a ship is entitled to fly the flag shown. The documents are thus not merely made evidence of the attribution of national character; they appear to be considered conclusive of that question.

\section{Claims with Respect to Flag}

The most conspicuous evidence of the attribution of national character to a vessel, though obviously it cannot be conclusive, is the display of a national flag. It is well established in the customary law of nations that each state has full freedom in deciding what shall be its national colors and who shall be accorded the right to fly its flag. ${ }^{242}$ It is an equally

bound to have with her, from the officers of her home port, either a register or an en. rolment. ... If found afloat, whether by steam or sail, without one or the other of these, and without the right one with reference to the trade she is engaged in, or the place where she is found, she is entitled to no protection under the laws of the United States, and is liable to seizure for such violation of the law, and in a foreign jurisdiction or on the high seas, can claim no rights as an American vessel.", 111 U. S. 734, at 736-737 (1884).

240 Colombos, op. cit. note 133 above, at 221; Fedozzi, "La Condition Juridique des Navires de Commerce," 10 Hague Academy Recueil des Cours 5, 49-50 (1925, V); 1 Oppenheim, op. cit. note 175 above, at 596.

241 One of the reasons for the high reliability of ship's documents is the severe penalties which national shipping laws provide for fraudulently obtaining and falsify. ing such documents. 18 U.S.C. $\$ 507$ (1958); 46 U.S.C. $\$ 60$ (1952).

2421 Oppenheim, op. cit. note 175 above, at 595; see also decision in the Montijo dispute between the United States and Colombia, 2 Moore, Digest of International Arbitrations 1421 (1898), discussed below, p. 113. 
firmly established rule of customary law that every vessel sailing on the high seas and entering foreign waters must fly a flag belonging to a state. Most national shipping laws expressly impose the duty upon all registered vessels to fly the flag of the state of national character. Thus, the Israeli Ships (Nationality and Flag) Ordinance of 1948, Article 3(a), reads:

Every ship registered in the State of Israel shall have the right and the duty to fly the flag of the Merchant Marine of the State of Israel. ${ }^{243}$

The Genera Convention states that "each State shall fix the conditions ... for the right to fly its flag" and requires that ships must sail "under the flag of one State only."

In view of both the ease with which flags can be changed and historic experience providing numerous examples of abuse of flag, the flag establishes only a prima facie outward evidence of a ship's national character; it is not conclusive. ${ }^{244}$ Since on the high seas the flag will in most cases be accepted as a correct indication of a ship's national character, states' regulations concerning the use of a national flag provide severe penalties for unlawful use of the national flag. Thus the British Merchant Shipping Act, 1894, declares in Section $69(1)$ :

If a person uses the British flag and assumes the British national character on board a ship owned in whole or in part by any persons not qualified to own a British ship, for the purpose of making the ship appear to be a British ship, the ship shall be subject to forfeiture. . . 245

The abuse or unauthorized use of a flag is treated in most countries as a criminal offense. 240

\section{Claims with Respect to Name of the Vessel}

Even the name of a vessel is considered important for purposes of identification both on the high seas and in foreign waters, as well as for registration. The change of a ship's name is in all maritime countries a matter which requires authorization of a responsible state organ. Unauthorized change of a vessel's name results in severe penalties and, for example, as provided in the Shipping Act of Chile, may result in the ship being deprived of its national eharacter. ${ }^{247}$ The statement by Oppenheim well expresses the practice of the majority of states in the matter:

Every State must register the names of all private vessels sailing under its flag, and it must make them bear their names visibly so that every vessel may be identified from a distance. No vessel may be allowed to change her name without permission and fresh registration. ${ }^{248}$

243 Laws Concerning the Nationality of Ships, op. cit. note 226 above, at 86 .

244 Thus, Higgins says: "Le pavillon n'est que le signe évident de la nationalité du navire, il ne suffit pas pour la prouver." Higgins, loc. cit. note 225 above, at 20.

245 Laws Concerning the Nationality of Ships, op. cit. note 226 above, at 184.

246 Colombos, International Law of the Sea 218 (3rd ed., 1954).

247 Art. 30(2), Shipping Act, 1878. Laws Concerning the Nationality of Ships, op. cit. note 226 above, at 20 .

2481 Oppenheim, op. cit. note 175 above, at 597. 
The mere exhibition of a name quite obviously offers no conclusive evidence of a ship's national character and has never been so regarded.

\section{E. Claims with Respect to "Genuine Link"}

It is most unfortunate that the Geneva Convention on the High Seas, though it introduces, in the requirement of Article 5 that "there must exist a genuine link between the State and the ship," a wholly new provision hitherto unknown either to the customary and treaty law of the sea or to the national shipping laws of any particular country, nowhere attempts to define what is meant by "genuine link" or to indicate by what procedures a definition might be attained. It is hardly less unfortunate that when one turns to the immense volume of travaux préparatoires, including both the proceedings of the International Law Commission and the proceedings of the Geneva Conference itself, one finds only darkening confusion mounted upon darkening confusion. The fact that so many of the world's experts on maritime law, having such extended opportunity to engage in clarification, made so little contribution to creating an unambiguous, workable reference for the words "genuine link" suggests that rational reference may be hard to come by. Indeed it remains for anyone even to suggest, much less clarify, an unambiguous reference for the words which can be regarded as either adequately serving the necessary function of evidencing states' attributions of national character or expressing acceptable policies for overriding states' attributions in the inclusive interests of the general community of states.

The earliest proposals made in the International Law Commission to limit the competence of states to attribute their national character to vessels can be found in the first report of the Special Rapporteur:

The attribution of an identity and a nationality to sea-going ships is the corollary of the principle of the free use of the high seas. Generally speaking, it is for every sovereign State to decide to whom it will give the right to fly its flag and to establish the regulations governing the granting of the right. In order that the legislation of a State on this subject should be effective, in all circumstances, however, it should not depart too far from the principles which have been adopted by the greater number of States and which may therefore be considered to constitute an element of international law in that connexion. ${ }^{249}$

By the time the Special Rapporteur presented his second report in 1951, what a year earlier constituted only "an element of international law" had become a set of "principles that have been adopted by nearly all States" and "constituting the basis of the international law on this matter." "250 According to this report, for purposes of recognition of a vessel's national character by other states, the following requirements must be fulfilled:

\footnotetext{
249 François, Report on the High Seas 6 (U.N. Doc. A/CN.4/17) (Report to Int. Law Commission, 1950).

250 François, Second Report on the High Seas 4 (U.N. Doc. A/CN. 4/42) (1951).
} 
1. More than one-half of the vessel should be owned by:

(a) Nationals or persons domiciled in the territory of the State to whom the flag belongs;

(b) A partnership or commandite company in which more than half the partners with personal liability are nationals or persons established in the territory of the State to whom the flag belongs;

(c) A national joint-stock company which has its head office in the territory of the State to whom the flag belongs;

2. The captain should possess the nationality of the State to whom the flag belongs. ${ }^{251}$

The provisional text of the prescription relating to nationality of ships adopted by the Commission at its 1951 session roughly corresponds to the above draft except for the requirement regarding the captain, which had been omitted as "too strict." 252

Few changes appeared in the draft adopted by the Commission in 1955.258

At its Eighth Session held in 1956, after the advent of the Nottebohm decision, the Commission, however, suddenly decided to replace the above elaborate scheme, perfected after more than five years of labor, with the following new text, which was subsequently placed before the Geneva Conference :

1. Each State shall fix the conditions for the grant of its nationality to ships, for the registration of ships in its territory, and for the right to fly its flag. Ships have the nationality of the State whose flag they are entitled to fly. Nevertheless, for purposes of recognition of the national character of the ship by other States, there must exist a genuine link between the State and the ship. ${ }^{254}$

The best evidence of what the Commission intended and of the policies it sought to serve by this innovation of "genuine link" must be found in the Commission's proceedings. We quote extensively the relevant parts of the discussions as reported in the summary records of the Eighth Session $^{255}$ of the International Law Commission:

251 Ibid. at 7-8.

252 U.N. General Assembly, 11th Sess., Agenda Item 53, p. 29 (1956-1957).

253 "Article 5. Right to a Flag. Each State may fix the conditions for the registration of ships in its territory and the right to fly its flag. Nevertheless, for purposes of recognition of its national character by other States, a ship must either:

1. Be the property of the State concerned; or

2. Be more than one-half owned by:

(a) Nationals or persons legally domiciled in the territory of the State concorned and actually resident there; or

(b) A partnership in which the majority of the partners with personal liability are nationals of or persons legally domiciled in the territory of the State concerned and actually resident there; or

(c) A joint stock company formed under the laws of the State concerned and having its registered office in the territory of that State." International Law Commission Report, U.N. General Assembly, 10th Sess., Official Records, Supp. No. 9, at 4 (U.N. Doc. A/2934) (1955); 50 A.J.I.L. 190, at 196 (1956).

254 International Law Commission Report, U.N. General Assembly, 11th Sess., Official Records, Supp. No. 9, at 24 (U.N. Doc. A/3159) (1956); 51 A.J.I.I. 154, at 168 (1957).

255 We cite page numbers in the text from 1 International Law Commission Yearbook, 1956 (Sales No.: 1956, V. 3. Vol. 1). 
Mr. François, Special Rapporteur . . . recalled the difficulties the Commission had encountered in formulating the conditions for recognition of the national character of a ship by other States. (p. 37.)

Mr. Salamanca. . . . Behind the stress on the necessity for "genuine connexion between the State and the ship" was probably the fear of competition from States with very liberal registration laws. Introduction of detailed conditions might have some effect on the freedom of the high seas. Such details should therefore be avoided. (p. 37.)

Mr. SPIRopoulos said that the issues raised by the article were highly complex and defied codification. (p.37.)

Mr. AMADo said that the problem was complicated by its various aspects: that of registration, which was the Netherlands approach; that of the flag, which the United Kingdom preferred; and that of the general principle of connexion between the State and the ship, which was stressed in the Netherlands proposal. . . . (p. 38.)

$\mathrm{Mr}$. Zourek [stated] that many States regarded registration as such [genuine] link. (p. 66.)

Mr. FrançoIs, Special Rapporteur, said that that did not meet the Commission's intentions. (p. 66.)

Faris Bey el-KHounI pointed out that, although not specifically defined, there was an adequate link between State and ship provided by the flag of the Member State. (p. 66.)

Sir Gerald Fitzmaurice. . . . Although perhaps it was the best that could be achieved in the absence of expert advice on the extremely complicated problems of nationality and registration, the articles as now drafted contained many obseurities. (p.67.)

Article 5 seemed harmless and was acceptable, although there could exist a genuine link between the ship and more than one State. However, he saw no way of overcoming that difficulty, except by adopting the United Kingdom criterion of effective control.

The question of nationality, unlike the question of jurisdiction to which the vessel is subject, was not of primary importance to the law of the high seas. (p. 68.)

Sir Gerald Frtzmaunice reaffirmed his view that the correct principle for the recognition of nationality was that of effective control. Consequently he would have preferred the third sentence in paragraph 1 to have read: "Nevertheless, for the national character of the ship to be recognized by other States, the flag State must be in a position to exercise effective control over the ship." (p. 262.)

Mr. Zourek. .... In spite of Sir Gerald Fitzmaurice's advocacy, he remained convinced that the fundamentally important question of nationality, which was intimately linked with the freedom of the high seas, must be dealt with in the draft, since otherwise ships would be free to change flags even during a single voyage. (p. 69.)

Mr. Amado did not think that Sir Gerald Fitzmaurice had offered any real reason for omitting a provision concerning nationality. He also wondered what the genuine link between the State and the ship would be if Sir Gerald Fitzmaurice's amendment . . . were adopted. Perhaps the very change of flag itself might constitute a link. (p. 69.)

Mr. SCELLE. . . . Surely the aim must be to eliminate the fictitious system of flags of convenience practiced by vessels claiming, for example, Panamanian or Liberian registry. (p. 68.)

Mr. Salamanca said it would be extremely difficult to determine what was a genuine link between a ship and its State of registry; perhaps the introduction of such a concept would go further than was required and would raise certain problems of ownership. States, particularly those with small merchant fleets, which had to follow a 
fairly liberal policy, might be apprehensive of transfers of registrya point which the Commission should take into account. (p. 69.)

Faris Bey el-KHour proposed the deletion of the second sentence of article 5 reading "Nevertheless, for purposes ... between the State and the ship," because only States themselves could decide whether a genuine link existed and only they could lay down the conditions for the registration of ships. The Commission must not seek to impose such control or sanctions in the present draft. (p. 69.)

Mr. Padilla-Nervo. . . . wished to make clear, however, that he was not wholeheartedly in favour of retaining the third sentence of article 5 , paragraph 1 , because he considered that the link between the State of registration and the ship was created precisely by the grant of nationality. . . . [I]t was not made clear on whom lay the burden of proving that the link was genuine. The requirement that there must be such a link before other States were bound to recognize the nationality of the vessel was not justified by international practice. There were fourteen treaties between the United States and other countries and thirty-eight between the United Kingdom and other countries, by virtue of which the signatory States recognized the nationality of vessels of the other signatory States as granted under the municipal law of the flag State. There were also seventy-three treaties which laid down that the nationality of ships was determined by the laws of the State to which they belonged. Consequently the third sentence in article 5, paragraph 1, was not only useless, but might conflict with international practice. (p. 70.)

IIr. Scelle. It would be for third States to decide whether a genuime link existed between the ship and the State of new registration and consequently whether the ship was entitled to fly its flag. The situation was analogous to a disagreement between two States over the nationality of an individual. (p.71.)

Faris Bey EL-KHourr. . . . confirmed the view he had expressed at the previous meeting that the third sentence in article 5, paragraph 1 , should be omitted, because it was for States themselves to establish whether there was a genuine link between them and the ship whose owner was seeking registration. States should not be suspected of traudulent practice in that regard. (p. 71.)

MIr. Salamanca reiterated the view that nothing had been gained by adopting the third sentence of paragraph 1 , because the requirement that there must be a genuine link between the State and the ship was altogether too vague and imprecise. (p. 72.)

Upon such a record, full of basic disagreements and abounding in confusion and irrelevancy, ${ }^{256}$ it was thus decided that states should be given authority to decide unilaterally "for purposes of recognition" whether there exists a genuine link between a given ship and the state of attribution.: ${ }^{57}$ A limitation of undefined content, such as genuine link, of which

256 As an indication of the confusion, the principal commentator on this aspect of the work of the Commission, Mr. Watts, apparently interpreted the Commission's references to a genuine link as meaning "omnership." Thus, rejecting the nationality of ships as the "'basis for protection," he concluded: "Since the right of a State to protect a vessel depenils upom its owner being a person whom that State may protect, any particular question concerning the right to protect a giren ship can only be answered by considering the exact standing of its owner." Watts, "The Protection of Merchant Shins," 33 Brit. Ir. Bk. Int. Law 79 (1957).

¿57 Voted upon separately, the requirement of genuine link received in the Commission 9 affirmative rotes against 3 negative ones and 3 abstentions. I Yearbook, op. cit. note 255 above, at 72 . 
exclusive unilateral interpretation is authorized, is of course the most severe and arbitrary limitation upon national competence, short of complete prohibition, that could be devised.

The Geneva Conference, as is known, adopted the substance of the Commission's draft, including the requirement of a genuine link. Extended debate among the delegates failed to bring much needed clarification to the meaning of the mysterious "genuine link." Quite to the contrary, the issue was even further confused by introduction of new elements into the elastic frame of reference of "genuine link." Thus, Mr. C. W. Jenks, speaking on behalf of the International Labor Organization, stated:

With regard to the reference in article 29 to a "genuine link" between the flag state and the ship, the Commission had drawn special attention to the obligation of the flag state to exercise control over such matters as safety regulations and lałour conditions. The ILO had devoted considerable attention to the problem, and the Preparatory Technical Maritime Conference it had held in $1956 \ldots$ had adopted a resolution urging that the country of registration should accept the full obligations implied by registration, and should exercise effective control. Among those obligations were securing the observance of internationally accepted safety standards, establishing government-controlled agencies to supervise the signing on and signing off of seafarers, ensuring that the service conditions of crews conformed with generally accepted standards, freedom of association for seafarers, proper repatriation arrangements and satisfactory arrangements for the examination of candidates for certificates of competency and for the issue of such certificates. In brief, the resolution stipulated as a minimum consequence of the registration of vessels that the country concerned should assume direct responsibility for ensuring that each vessel registered complied with safety standards, was properly manned and was navigated by competent persons. . . . It was to be hoped that if the Conference on the Law of the Sea attempted to define the genuine link more precisely those factors would be taken into account. ${ }^{258}$

Mr. François, acting in Geneva as the Expert to the Secretariat of the Conference, further elaborated upon this same theme in the attempt, as he put it, to "shed light on the Commission's intentions on certain points or dispel any misunderstanding that might exist as to the interpretation of certain articles of the draft":

Some delegations do not agree with article 29 , which requires the existence of a genuine link between the ship and the state whose flag it flies. It had been urged that the freedom of the seas subsumes the sovereign right of states to grant authority to fly their flag. The International Law Commission does not share that view. It admits that a system under which any state can grant its flag to all ships applying for it is in fact the acme of freedom. That conception of freedom is, however, incompatible with the interests of the international community. ... The essential corollary to the freedom of the seas must be that states exercise the same jurisdiction over ships sailing the high seas under their flag as they exercise in their own territory. ... This régime is based on the notions that the ship must in the main belong to nationals of the flag state; that the owners must be domiciled in that

2584 Official Records 26. 
stute; that the officers and at least the major part of the crew must be nationals of that state; that in foreign ports the consular officers of the flag state shall exercise the necessary control over such ships putting in at those ports and, where appropriate, grant them such protection as they may need; and, finally, that the ships shall return to their home ports at regular intervals. That is what the International Law Commission understands by the link between the ship and the flag state. If that link no longer exists, the entire system collapses, and a situation will arise on the high seas which some may regard as the ideal state of freedom, but which others-including the International Law Commission-regard as contrary to a sound conception of the freedom of the seas, and hence to the interests of the international community. The nature of this genuine link, and the consequences of its absence, will have to be specified; and there is little likelihood that the present conference, which is already over-burdened, will be able to deal with the matter. It is important, however, that it should come out in favour of the principle, the details of which will be studied subsequently. ${ }^{2 \pi s}$

Subsequent discussion in the Second Committee, however, failed to produce any greater clarity and consensus with respect to the content of a genuine link. Mr. Seyersted (Norway), emphasizing "the greatest importance" which his government attached to the "genuine link" requirement, insisted that "effective jurisdiction and control were an indispensable feature of the genuine link," and continued:

There were others, such as the nationality or domicile of the owner, his principal place of business, the nationality of the officers and erew and the extent to which parties suing the shipowners could effectively have recourse to the courts of the flag State, but it would be difficult to single out any one of them as indispensable. It was the sum total of all those elements which mattered. ${ }^{250}$

Mr. Edelstam of Sweden, in contrast to the vast majority of other delegates, found the issue perfectly clear and declared:

... the principle of the genuine link was almost self-evident, since without it ships on the high seas rould not be subject to the authority of any State. ${ }^{261}$

Mr. Van Panhuys (Netherlands), in disregard of all history, was emphatic in his support of the "genuine link" requirement:

He could not subscribe to the contention that the term used by the Commission was too general and would lead to confusion. On the contrary, without the principle of the genuine link there would be a legal vacuum, since the counterpart of freedom of navigation must be the obligation of the flag State to maintain order on the high seas. ${ }^{262}$

259 Ibid. 34-35.

260 Ibid. 62 .

201 Ibid. 64.

202 Ibid. Another recent exercise in interpretative frustration with respect to the content of genuine link is provided in Brajkovic and Pallua, "Les conditions dans lesquelles les Etats accordent aux narires le droit d'arborer le pavillon national," International Academy of Comparative Law, Vth International Congress of Comparative Law, Sec. IV. C. 1, General Report, Bruxelles (1958). Having established that the genuine link formula requires "comparative investigation" (p. 7), the authors, referring to the vagueness of the available and suggested criteria, note: 'Le fait qu'on $n$ 'a pas 
Admiral Colclough of the United States, after correctly observing that all the talk about the perils to the freedom of the seas totally lacked evidence of instances where effective jurisdiction nad not been exercised, summarized as follows :

The only principle which had been advanced as the basis for the concept of non-recognition was that of the "genuine link." But the International Law Commission itself had admitted that the genuine link was a vague criterion, and that vagueness was not removed by the addition of the words "effective jurisdiction and control." Effective jurisdiction and control did not constitute a criterion, but an objective. and hence did nothing to clarify the term "genuine link."

In effect, it was proposed that States should be told at one and the same time that the Conference did not know what the genuine link was, but that if they found that the genuine link did not exist, in a particular case, they were free not to recognize the nationality of the ship concerned. ${ }^{263}$

In a publication after the adoption of the Convention on the High Seas, Professor Sørensen has also attempted, despite the failures of the International Law Commission and the Geneva Conference, to give a content to the "genuine link" requirement. This is his interpretation:

The Commission made no attempt, however, to define a "genuine link." It felt-as did the Geneva Conference-that the legislation of traditionally maritime states was too divergent to permit of any internationally binding definition. Among the criteria that may be used are nationality or domicile of the owner, his principal place of business, nationality of officers and crew. In the case of ships owned by joint-stock companies, the criteria may include nationality or domicile of the shareholders or of a certain proportion of them. ${ }^{264}$

Referring to the words of Article 5: "In particular, the State must effectively exercise its jurisdiction and control in administrative, technical and social matters over ships flying its flag," Professor Sørensen further explains :

This sentence ... in effect relates the "genuine link" not only to the qualities of the ship and its owner, but also to the legal possibilities of the state to control the ship. If such possibilities are absent, the state is not entitled to enter or to maintain the ship on its register."ws.

No elaborate dissection, however enjoyable it might be, of these extensive quotations is required to demonstrate that neither official nor unofficial commentators have succeeded in suggesting a possible definition of a genuine link which is either clear or acceptable by criteria of community interest.

Turning from contemporary controversy to the historic requirements of states in their national shipping legislation, it is equally impossible to find a meaningful reference for "genuine link" which would serve the general community interest either in evidence of states' attributions of national

défini ces limites d'une façon stricte permet une assez grande liberté de choix des critères admissibles." Tbid. at $16 . \quad 2634$ Official Records 64-65.

264 Sørensen, The Law of the Sea 204 (Intermational Conciliation, Pamphlet No. 520, 1958). 265 Ibid. at 205. 
character or in policies overriding their competence to attribute. The words of a renowned French lawyer of the 19th century, Ortolan, are still fully applicable:

Les nations, dans l'établissement de ces conditions, seront évidemment plus ou moins faciles, plus ou moins rigoureuses, selon ce qu'elles croiront le plus de leur intérêt; selon l'état de prospérité, de développement, d'enfance, ou de décadence où se trouvera leur marine; suivant le degré de leurs ressources maritimes en matériel ou en personnel. ${ }^{268}$

It will be recalled that these traditional national requirements are related to the ownership of the vessel, nationality of the erew and place of the ship's construetion.

\section{(a) Ownership}

That a state may attribute its national character only to vessels owned by its nationals has never been a requirement of international law. After a careful analysis of the historic practice of states, Rienow concludes:

There is actually no correlation between ownership and nationality; the treaties and correspondence of States do not indicate the need for national ownership; and although some States refuse to consider as of their own respective nationalities, vessels, the titles to which are not held by nationals, their practice indicates that they do not deny other States the privilege of dispensing with this requirement. Moreover, the bare fact of national ownership does not impress upon a vessel a closer connection with the State of the owner's nationality than with any other State. ${ }^{267}$

This freedom from inclusive restraint characterizes international treaties relating to navigation, which are uniform in considering the question of ownership as irrelevant. On the basis of a study of 150 such treaties, Professor Hawkins reached this conclusion:

While national laws do commonly limit national registry to vessels owned by the nationals of the country concerned, it is not this requirement but the fact that the vessel has been admitted to national registry that is significant from the treaty standpoint. . . .

Under such treaty provisions, nationality of the vessel is determined solely by the state of registry irrespective of the nationality of the owner. ${ }^{268}$

266 Ortolan, Règles internationales et diplomatie de la mer 167 (4th ed., 1864). For a modern statement with respect to these policies see Van Bogaert, "Le Droit que Possède l'Etat pour Déterminer les Conditions d'après Lesquelles les Navires ont le Droit d'Arborer son Pavillon," 35 Rev. de Droit International et de Droit Comparé 485, at $486-487$ (1958).

267 Rienow, The Test of the Nationality of a Merchant Vessel 116 (1937).

268 Hawkins, Commercial Treaties and Agreements 6 (1951). Writing on the same subject, Walker states: "A vessel, by definition, is deemed to have the nationality of the country whose flag it lawfully flies, without reference to such questions as who owns it or where it was built ..." Walker, "Provisions on Companies in United States Commercial Treaties," 50 A.J.I.L. 373, at 382 (1956). 
The late Professor Hyde is similarly unequivocal when he states:

It is probably a sound proposition that a vessel registered under the laws of a State and possessed of a certificate of registry may be deemed in an international sense to belong to that State, and to justify it in giving it the privilege of flying its flag, regardless of the nationality of the owners of the ship. ${ }^{269}$

The requirement of national ownership is most obviously a requirement of exclusive policy, which has its roots in conditions of a distant past, long ago profoundly changed. ${ }^{270}$ Thus, when ships were scarce and the most highly prized assets of national bases of power, and when secrecy surrounding the art of shipbuilding was equal to the present-day secrecy enveloping the art of rocketry, the requirement that only vessels wholly owned by nationals could be attributed a national character was entirely rational and universally employed. With the disappearance, however, of the conditions which prompted the introduction of this criterion, the latter's strictness and universal application have also changed. The development of modern capitalism with all its refined and complex forms of corporate organization transcending state boundaries, the growing practice of foreign investment, and the pressing need for capital in the newly emerging underdeveloped states-all these have contributed to changes in national policies of many countries. Today only a minority of states requires that the ressels having their national character be wholly owned by their nationals. Some traditionally maritime countries, such as, for example, Italy, France, The Netherlands and Sweden, are satisfied with their nationals having the controlling interest in the ship. Other states, on the other hand, have no requirements relating to ownership at all. It must not be overlooked, further, that even in states with the strictest and most complete requirements relating to ownership by nationals, "national" often includes a "nationally incorporated" association, which of course allows non-nationals to have an ownership interest in vessels having the national character of these countries. ${ }^{271}$ This practice was known to and approved by Dr. Lushington more than a hundred years ago, as is clearly demonstrated by the following statement made in The Johanna Emilie:

2631 Hyde, International Law 810 (2d rev. ed., 1945).

$2 \pi 0$ An 18th-century author had this to say with respect to the policies which were to be promoted by the enactment of the British Narigation Act of 1651: "The great object of jealousy at the time of passing this Act was the immense carrying trade possessed by the Dutch. ... The portion of the carrying trade with our colonies, which the Dutch had obtained, was the most serious grievance, and that which the nation bore with least patience. . . . The ordinance sets out with a regulation that was to strike at this abuse." Reeves, History of the Law of Shipping and Navigation 37 (1792). See also a more recent appraisal, Chorley and Giles, Shipping Law 3 (3d ed., 1952).

271 Thus Professor Smith writes: "English law requires the complete legal ownership to be vested in British subjects, but this requirement is of less value than might appear, since it does not exclude ownership by a British company in which the controlling interest is held by foreigners." The Law and Custom of the Sea 64 (3d ed., 1959). Higgins puts it this way: "Lorsque, comme c'est sourent le cas, le navire est la propriété d'une société, il $n$ 'est pas toujours aisé de déterminer la nationalité de cette société." Loc. cit. note 225 above, at 21. 
... it is perfectly notorious that the merchants of Great Britain have repeatedly, at various times, been owners of foreign vessels sailing under foreign flags, - a privilege of which they would be very sorry to be deprived-a privilege ... they are entitled to exercise. ...272

\section{(b) National Build}

That a state may attribute its national character only to vessels which have been built within its territory has never been a requirement of international law. ${ }^{273}$ This again is a matter of national policy, and equally in regard to this requirement the practice of states is today vastly different from what it was a couple of centuries ago. Such stipulation does not seem to be even a national requirement any longer except in the shipping laws of the United States, Portugal and France. Among these, it appears that the United States alone most strictly adheres to this commonly regarded anachronistic policy. ${ }^{274}$

It is gratifying to note that the records do not reveal that national build has ever been considered as a potential "genuine link" by either the International Law Commission or the Geneva Conference.

\section{(c) National Crew}

The requirement that all or a fixed proportion of ship's personnel be nationals of the flag state similarly has never been a requirement of international law. ${ }^{275}$ On the contrary, it has always been and still remains a matter of national policy with respect to which every state fully exercises an exclusive competence. Any doubt that may have existed in this respect must have been eliminated by the decision in the IIontijo controversy between the United States and Colombia. ${ }^{278}$ The umpire, Robert Bunch, British Minister Resident in Bogotá, rejecting the Colombian contention that the Montijo could not claim the national character of the United States, since the composition of its erew was not in accord with the relevant American requirements, asserted that the alleged violation of American law was "rather a question for the Government of the United States than for this tribunal of arbitration." ${ }^{277}$ Further, the umpire declared that he could "not go behind the undoubted fact that the Government of the United States considers the Montijo as an American ship," and concluded that "On this point it is the sole judge." 278

272 Quoted in Rienow, op. cit. note 267 above, at 92.

$273 \mathrm{Ibid}$. at $24-49$.

274 See 46 U.S.C. $\$ 11$ (1952). However, foreign-built vessels mar be registered but are not allowed to engage in United States coastwise trade. Ibid. With respect to both France and Portugal, the statutes of these countries which require national construction contain escape-clauses making this requirement rather illusory. For France, see 1 Ripert, Droit Maritime 301 (4th ed., 1950); for Portugal, compare Arts. 2 and 3(1) of the Shipping Act of 1863, in Laws Coneerning the Nationality of Ships, op. cit. note 226 above, at $145-146$. 275 Rienow, op. cit. note 267 above, at 73.

278 The Mlontijo, 2 Moore, Digest of International Arbitrations 1421 (1898) (Decision of the Umpire of July 25,1875 ). 277 Ibid. at 1433 .

278 Ibid. at 1434 . 
An attempt made by some members of the Institute of International Law more than sixty years ago to limit the competence of states in this regard was rejected by the majority of the members and resulted in the adoption of the following recommendation:

Article 4. Each State shall determine the conditions to be fulfilled in order to be appointed captain or first officer of a merchant ship : but the nationality of the eaptain or that of the members of the erew shall not be a condition of aequiring or forfeiting the right to the national flag. ${ }^{279}$

Thus, historic experience, exhibiting vast differences in the shipping laws of various countries with respect to the composition of ships' crews, demonstrates that this, too, is a requirement expressing only exclusive national policies.

\section{Conclustveness of Conclusion for Conclusiveness}

The high degree of conclusiveness which states have in the past uniformly accorded in mutual tolerance to their attributions of national character to ships has contributed inestimably, as our review of past trends in decision has demonstrated, to their securing shared use of, and shared competence over, the great common resource of the oceans. By their mutual tolerance states have achieved co-operative action on an ever-expanding scale in the joint production of the greatest net values for all. Indeed, it is this model of co-operation which is commonly regarded as the most relevant experience for shaping the preliminary outlines of an emerging law of outer space.

Conversely, the high degree of conclusiveness which states have reciprocally accorded their respective attributions of national character to vessels has not impeded the rational handling of problems and controversies arising from interactions across boundaries in which their common interests in the shared use and competence over the oceans are only incidentally at stake. The fact that a state may have attributed its national character to a vessel has been, as we have seen, regarded as an appropriate factor for consideration in many of these controversies, but it has been regarded as merely one factor among many to be appraised in context for clarifying relevant community policy. In the disposition of these problems, the significance of attributions of national character to vessels has been in their bearing upon the traditional tasks of "private international law," determinations of "reasonableness" and the requirements of "security" and "comparative justice."

The introduction into this rational process of decision of the new-found contrivance of genuine link could do incalculable harm. It could make statelessness commonplace when so far it has existed only as an extreme rarity; it could undermine, if not render worthless, an enormous number of bilateral treaties of commerce and navigation, which require recognition of unilateral competence to determine national character; it could result in

279 Annuaire 202 (1896) (translation from U.N. General Assembly, Official Records, Agenda Item 53, at 29) 
assertions of an unrestricted right of visit and search against vessels navigating on the high seas suspected of the absence of a genuine link with the state whose flag they otherwise lawfully fly; it could encourage arbitrary and uncontrollable diserimination by states against vessels of other states; it could create international tension by authorizing unilateral interferences in matters hitherto regarded as of strictly national competence, to wit: the comprehensireness or appropriateness of a state's shipping legislation; it could introduce destructive uncertainty into commereial intercourse between states and between individuals as well; it could affect most adversely all forms of foreign investment by creating expectations that the genuine link doctrine might suddenly be extended from shipping to other industries; it could deprive of work thousands of seamen of all nationalities and, perhaps, an even greater number of workmen employed in related industries; it could deny for all practical purposes access to the oceans to states which presently lack capital and skills indispensable for independent maritime industry; and so on, in realistic horribles in expectation.

It is yet to be demonstrated that any conceivable good for the common interest of peoples could attend the introduction of this new-found requirement of genuine link. It has not been established that it would be an economic technique for achieving the laudable aims of labor for more suitable working conditions and higher standards of living. It has not been established that it is an economic technique for remedying the ills that business interests find in competition, even if it be assumed that these ills are entirely real and not hypochondriacal. Finally, it has not been established that safety of navigation or any other shared interest in common use of the oceans would in any way be improved. It has not, in sum, been established that the proposed innovation would serve any common interest which might counterbalance the very grave risks and dangers which it would entail. On the contrary, it would seem reasonably elear that the ouly purposes it would serve are those of disruption, controversy and anarchy. 280

Registration alone, accordingly, recommends itself, as has been demonstrated in detail above, as the most appropriate "link," in attribution of national character, between state and ship. It serves best both the exclusive interests of states in freedom to determine their own maritime development and the inclusive interests of the general community of states in simple, economic modalities for identifying the national character of ships. When accompanied by necessary documents issued by competent authorities of the state which has attributed its national character to the vessel, it may be relied upon as best suited to secure both types of shared interests.

$280 \mathrm{~A}$ foretaste of the wide possibilities for abuse which the doctrine of genuine link jrovides is afforded by a news item reporting the first conerete application of this innovation. The report states that the U.S.S.R. has issued an order which imposes upon all ships flying supposed flags of convenience harbor fees approximately three times higher than those applicable to vessels of traditional maritime countries. New York Times, Aug. 31, 1958, $\$ 5$, p. 11. Since it is commonly known that some 40 percent of these ships are owned by American corporations, it is easy to see that the genuine link's first practical test has taken place on the cold-war battlefield. 
The conclusion to which we, therefore, inevitably come is that the states of the world should reject this segment of Article 5. This could be done by maliing appropriate reservation upon any ratification of Article 5 or by stating in advance its only acceptable interpretation. The agreement by all ratifying states upon appropriate reservation, interpretation, or, best of all, deletion, would of course be the procedure most economically designed to secure the common interest. ${ }^{281}$

281 Some degree of recognition of the perils inherent in the "genuine link" doctrine is to be seen in the outcome of the rote taken in the Plenary Session of the Genera Conference upon the words "for purposes of recognition of the national character of the ship by other States." These words received the support of only 15 states, whereas 30 states voted against them, and 17 abstained, out of a total of 86 states attending the conference. 2 Official Records 20. 